Andrews University

Digital Commons @ Andrews University

1998

\title{
A Strategy for the Establishment of Seventh-day Adventist Chaplaincy in the Ghana Armed Forces
}

Peter Kwasi Omane

Andrews University

Follow this and additional works at: https://digitalcommons.andrews.edu/dmin

Part of the Practical Theology Commons

\section{Recommended Citation}

Omane, Peter Kwasi, "A Strategy for the Establishment of Seventh-day Adventist Chaplaincy in the Ghana Armed Forces" (1998). Professional Dissertations DMin. 640.

https://dx.doi.org/10.32597/dmin/640

https://digitalcommons.andrews.edu/dmin/640

This Project Report is brought to you for free and open access by the Graduate Research at Digital Commons @ Andrews University. It has been accepted for inclusion in Professional Dissertations DMin by an authorized administrator of Digital Commons @ Andrews University. For more information, please contact repository@andrews.edu. 


\section{ABSTRACT}

\section{A STRATEGY FOR THE ESTABLISHMENT OF SEVENTH-DAY ADVENTIST CHAPLAINCY IN THE GHANA ARMED FORCES}

\section{by}

Peter Kwasi Omane

Adviser: James North, Jr. 


\title{
ABSTRACT OF GRADUATE STUDENT RESEARCH
}

Dissertation

\author{
Andrews University \\ Seventh-day Adventist Theological Seminary
}

Title: A STRATEGY FOR THE ESTABLISHMENT OF SEVENTH-DAY ADVENTIST CHAPLAINCY IN THE GHANA ARMED FORCES

Name of researcher: Peter Kwasi Omane

Name and degree of faculty adviser: James North, Jr., D.Min. Date completed: June 1998

\section{Problem}

There are many Adventist military personal and their families in the Ghana Armed Forces. This has led to the establishment of two organized churches and two companies in the military barracks. Since most of the Adventist military personnel are enlisted persons (non-officers), there is a need for an officer as a spokesperson.

The interest that non-Adventist military personnel had shown in the Adventist message, especially in the areas of marriage, health, and evangelism, calls for a wellestablished Adventist chaplaincy ministries not only to win souls but to retain them.

The Ghana Armed Forces has made a request to 
Seventh-day Adventists to provide them with chaplains.

Pastors in Ghana will respond to this challenge if they know what their work will be.

\section{Method}

The biblical foundation of military chaplaincy was developed from the old and New Testaments. A summary of the history and structure of the Ghana Armed Forces is given as it relates to chaplaincy. Interviews and research into books and the armed forces communication sources were used to gather information and suggestions to establish seventhday Adventist chaplaincy ministries in the Ghana Armed Forces.

\section{Results}

Research shows that the major reason why Seventh-day Adventists had not been able to establish chaplaincy ministries in the Ghana Armed Forces is the fear of unknown expectations and presumed career uncertainty in the armed forces.

The manual in this paper, therefore, gives almost all the needed information about chaplaincy in the armed forces and develops a strategy for the establishment of chaplaincy in the Ghana Armed Forces.

\section{Conclusion}

The West Africa Union and the Africa-Indian Ocean Division need to create Adventist chaplaincy ministry positions at each level to coordinate with the General 
Conference Adventist Chaplaincy Ministries office. This chaplaincy department will recruit and coordinate military chaplains not only in the Ghana Armed Forces but armed forces throughout Africa. Chaplaincy ministries need to be established in the armed forces, and the stage seems to be set for making an effort to have Adventist chaplains in the armed forces. 


\title{
Andrews University Seventh-day Adventist Theological Seminary
}
A STRATEGY FOR THE ESTABLISHMENT OF SEVENTH-DAY ADVENTIST CHAPLAINCY IN THE GHANA ARMED FORCES

\author{
A Dissertation \\ Presented in Partial Fulfillment \\ of the Requirements for the Degree \\ Doctor of Ministry
}

by

Peter Kwasi Omane

March 1998 



\title{
A STRATEGY FOR THE ESTABLISHMENT OF SEVENTH-DAY ADVENTIST CHAPLAINCY IN THE GHANA ARMED FORCES
}

\author{
A dissertation \\ presented in partial fulfillment \\ of the requirements for the degree \\ Doctor of Ministry
}

by

Peter Kwasi Omane

APPROVED BY THE COMMITTEE:
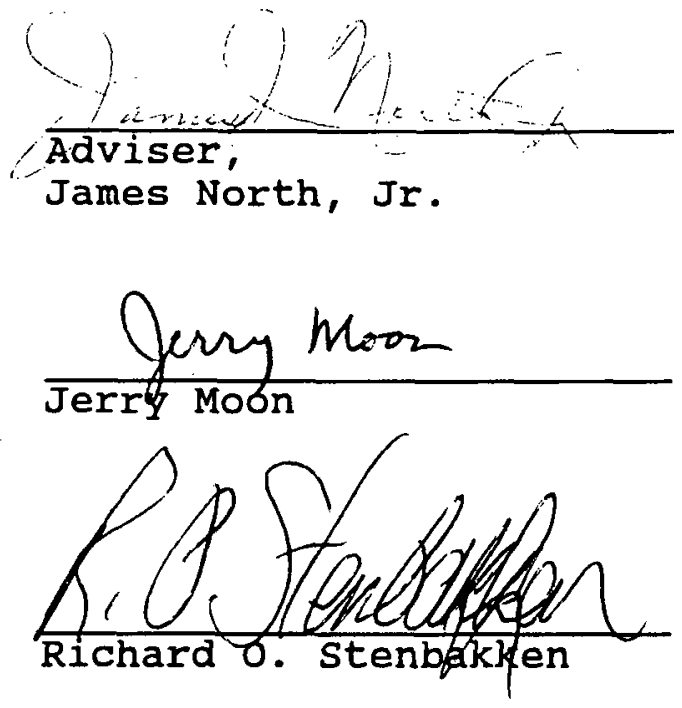

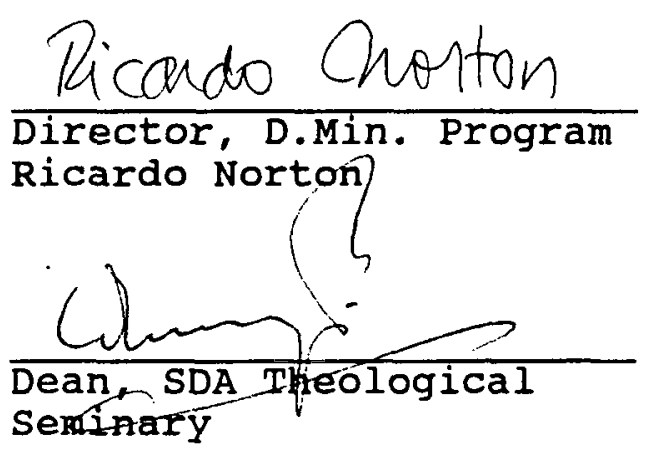

$$
\frac{M y 22,1998}{\text { Date } 2 \text { approved }}
$$


To my mother, Grace Adwoa Werayowaa Aboagye, who decided to finance my education through hard work and personal sacrifice. Her early morning loud prayers that asked for God's protection for me inspired me to depend upon God for success. May God bless her. 
TABLE OF CONTENTS

Chapter

ACKNOWLEDGMENTS . . . . . . . . . . . . . . . . vii

I. GENERAL INTRODUCTION

Purpose of the Dissertation . . . . . . . . 1

Background of the Dissertation . . . . . . . 1

Justification of the Dissertation . . . . . 2

Description of the Project . . . . . . . . . 3

Limitations of the Project . . . . . . . . . . 4

Expectations of the Project . . . . . . . . 4

Methodology ................ . 5

II. THEOLOGICAL BASIS FOR MILITARY CHAPLAINCY . . . . 6

The old Testament . . . . . . . . . . . 6

The New Testament . . . . . . . . . . . . 12

Summary . . . . . . . . . . . . . . 17

III. SEVENTH-DAY ADVENTISTS AND THE GHANA ARMED FORCES. - 19

A Short History of the Ghana Armed Forces . . 19 Composition of the Army . . . . . . . . . 22

The Ghana Armed Forces and Politics . . . 23

Religious Rights of Ghana Armed

Forces Personnel .......... . 24

Seventh-day Adventists in the Ghana

Armed Forces .............. 26

History of the Establishment of the Adventist Congregation . . . . . . 27

Problems Encountered by Seventh-day

Adventists ..... . . . . . . 30

Potential for Growth . . . . . . . . . 33

Seventh-day Adventist Attitudes Toward

Military Chaplaincy . . . . . . . . . 34

Summary

IV. THE CHAPLAIN'S HANDBOOK: A MANUAL FOR SEVENTH-DAY ADVENTIST MILITARY CHAPLAINCY IN THE GHANA

ARMED FORCES 
Introduction

Military Regulations and Customs Governing

the Placement and Functions of

Chaplains

Status of Chaplains: Entry

Prerequisites . . . . . . . . . . 39

Chaplain Duties: Pastoral Ministries . . . 40

Chaplain as an officer... . . . . . . . 43

Dress ................. 43

Military Courtesies . . . . . . . . . 44

Physical Fitness . . . . . . . . . 45

Relationship to other Commands . . . . . 45

Relationship to Commanders . . . . . 45

Relationship to staff .. . . . . . . 45

Chaplains and Non-Combatancy . . . . . . 46

Chaplain Promotions .. . . . . . . . . 46

Chaplain as a Captain .. . . . . . . 46

Chaplain as a Major . . . . . . . . . 47

Chaplain as Lieutenant Colonel . . . 48

Chaplain as a colonel . . . . . . . 49

Crisis Ministries . . . . . . . . . . . 49

Coping with Grief . . . . . . . . 50

Family Problems ...... . . . . 52

Divorce and Remarriage . . . . . . . 53

Mental Disorders .. . . . . . . . 56

Alcoholism .............. 56

Addiction . . . . . . . . . . . 57

Marital Problems .. . . . . . . . 58

Premarital Counseling . . . . . . . 60

Physical Illness . . . . . . . . . 61

Violence and Abuse .. . . . . . . 62

Choosing Marriage Partners . . . . . 63

Religious Programs .. . . . . . . 65

Recommended Sequence for Placing Seventh-day

Adventist Chaplains in the Ghana

Armed Forces . . . . . . . . . . . . 67

Internal Church Procedures and Adjustments to Select Persons for Military

Chaplaincy ... . . . . . . . . . 68

The Ghana Armed Forces Expectations of

Seventh-day Adventist Chaplains . . . . . 71

Seventh-day Adventist Expectations of

Adventist Chaplains in the Ghana Armed

Forces . . . . . . . . . . . . . . . 73

Suggestions for Ghana Armed Forces Evangelism

Including Healthful Living Seminars and

Marriage Seminars . . . . . . . . . . 77

Health Seminars . . . . . . . . . 79

Marriage Seminars ....... . . . 82

Evangelistic Outreach . . . . . . . 85

Sabbath Issues . . . . . . . . . . . . 92 
Noncombatancy in the Ghanaian Military . . . . 93

Issues of Noncombatancy . . . . . . . 95

The Historical Seventh-day Adventist

Position on Bearing Arms . . . . . . 95

Bearing Arms in the old

Testament . . . . . . . . . . . 97

Bearing Arms in the New

Testament . . . . . . . . . . 103

The Ghanaian Seventh-day Adventist

Chaplain and the Question

of Bearing Arms . . . . . . . . . . . . 116

Seventh-day Adventists in the Ghana

Armed Forces and the Bearing

of Arms . . . . . . . . . . . . . . . .116

Advice to Seventh-day Adventists Diet

regarding the Ghana Armed Forces . . . 117

Regularity, simplicity and

other Issues

Balance . . . . . . . . . . . 120

V. SUMMARY AND RECOMMENDATIONS . . . . . . . . . . 122

Introduction . . . . . . . . . . . . . 122

Summary . . . . . . . . . . . . . . 122

Recommendations ........... 126

Appendix

A. LETTERS . . . . . . . . . . . . . . . . . . 129

B. RECOGNITION OF RELIGIOUS BODIES PETITION . . . . 136

C. RECOGNITION OF SEVENTH-DAY ADVENTIST CHURCH . • • 141

D. CHAPLAINCY BRANCH OF THE ARMY . . . . . . . . . 143

E. E. G. WHITE AND SEVENTH-DAY ADVENTIST

TEACHING ON MILITARY SERVICE . . . . . . . . 146

F. BRIEF EXPLANATION OF THE SEVENTH-DAY

ADVENTIST CHURCH POSITION ON

BEARING OF ARMS . . . . . . . . . . . . . . . .160

BIBLIOGRAPHY •. . . . . . . . . . . . . . . . 162

VITA . . . . . . . . . . . . . . . . . 171 


\section{ACKNOWLEDGMENTS}

To God be the glory for what has been accomplished in this dissertation. I wish to express my deep appreciation to the following individuals without whom this study would not have materialized: Dr. James North, chairman of my committee, who not only guided me throughout the development of this dissertation but also encouraged me; and Dr. Jerry Moon, who with gladness agreed to be a member of the committee, and also showed a lot of interest in this dissertation by his dependability and consistency in a timely manner.

I would also like to express my gratitude to Dr. Richard 0 . Stenbakken, Director of Adventist Chaplaincy Ministries, General Conference of Seventh-day Adventists, whose encouragement and support made this dissertation a reality.

Special thanks to Bonnie Beres for editing and making this paper reach Andrews standards. Bonnie Beres has not only been helpful to me by editing almost all my term papers at Andrews but also to many people from developing countries whose first language is not English. May God bless her.

I am grateful to the following people who read and edited this paper: Mr. Isaac Annan (his fatherly love), 
Pastor John K. Amoah, Pastor Kwabena Donkor, Dr. Matthew Quartey, Mrs. Joyce Jones, Professor Kofi Appiah and his wife Jane, Pastor Hermann V. Kuma, Enoch Damson, Kwabena Affum Addison-Amponsah, Henrietta Faakye, and Hilda OpuniMensah.

I would like to thank Bonnie Proctor, the dissertation secretary, for her direction with this document.

I am thankful to Mr. and Mrs ohene Aboagye of Norway, for the money they have invested in my education.

I am thankful to my brothers and sisters: Paul $\mathrm{K}$. Danso, Ohene Aboagye, Mary Abena Akoma, Kwaku Owusu, Collins Omane, willberforce Kwabena Boateng, Nana Abena Adu (Mame Jane), Adjei Badu, Kofi Doku, and Akosua Denkyira (Akos).

A special thanks goes to my father, Peter Kwame Omane, and my mother, Grace Adwoa Werayowaa Aboagye.

I would like to thank the Burma Camp SDA Church and also Lt. Col. Isaac Buabeng, Lt. Col. Opuni-Mensah, and Captain Embrah Buabeng.

Finally, I express my love and deep appreciation to my wife, Linda Ohenewaa Omane, my children, Jonathan Kofi Omane, Kofi Danso Omane, and Kofi Aboagye Omane for, their prayers, support, and understanding during all these toilsome years of study. 
CHAPTER I

GENERAL INTRODUCTION

\section{Purpose of the Dissertation}

The purpose of this project was to develop a strategy for establishing Seventh-day Adventist (SDA) Chaplaincy Ministries in the Ghana Armed Forces.

\section{Background of the Dissertation}

Before June 1985 there were no facilities for Seventhday Adventist military personnel and their families in the Ghana Armed Forces. In June of 1985 a group of sixteen Seventh-day Adventists held an evangelistic crusade at Burma Camp in Accra. This resulted in the organization of ninetysix military members and their families into a seventh-day Adventist congregation. As a result of this crusade, which included the work of two Seventh-day Adventist military officers, ${ }^{1}$ the Ghana Armed Forces offered land for the building of a church for Adventist service people and their dependents at Burma Camp.

${ }^{1}$ Lt. Col. Fred opuni-Mensah and Lt. Col. Isaac Kwaku Buabeng are credited for organizing both the 1985 crusade in Burma Camp and the subsequent appeal to the Ministry of Defense for Adventist recognition. 
The work of those two officers in organizing a congregation in Burma Camp also resulted in the acceptance of the Seventh-day Adventist church as the seventh church organization fully recognized by the Ghana Armed Forces.'

The number of Adventist congregations has continued to increase. Presently, several SDA groups are meeting in a gymnasium, inter-denominational churches, homes, and school buildings. It is hoped that, with the growth of Adventist military personnel, there will be Adventist church buildings for worship. The Ghana Armed Forces regulations require each recognized denomination to have its own church building(s).

While the other six churches have chaplains to do pastoral work among their adherents, Seventh-day Adventist military people have no chaplains.

Since 1985, the Seventh-day Adventist military work has grown to three churches and two branch Sabbath Schools and is functioning as best it can with lay and civilian pastoral leadership.

\section{Justification of the Dissertation}

The following facts suggest the need for Adventist chaplains:

${ }^{1}$ The other six accepted organizations are the Roman Catholic Church, Methodist Church, Presbyterian Church of Ghana, Evangelical Presbyterian Church, Anglican, Church and the Muslims. 
1. Adventists need Adventist chaplains because of the uniqueness of Seventh-day Adventist doctrines and teachings such as the Sabbath, noncombatancy, and diet.

2. Enlisted persons (non-officers), who form 95 percent of Adventist military personnel, need an officer as a spokesperson, particularly in the above religious matters.

3. Non-Adventists need Adventist chaplains because non-Adventists have appreciated the work of Adventists in the areas of marriage and health. Adventist chaplains would have a great opportunity for marriage and health seminars.

4. Adventist chaplains are needed to supervise evangelistic outreach to non-Adventists in the armed forces. The stage seems to be set and the time seems appropriate for making an effort to have Adventist chaplains in the Ghana Armed Forces.

\section{Description of the Project}

A biblical foundation of military chaplaincy is developed from the old and New Testaments. A summary of the history and structure of the Ghana Armed Forces is also given as it relates to its chaplaincy. Telephone interviews were conducted with current SDA leaders and lay persons whose efforts in Burma Camp brought about the first organized Seventh-day Adventist military congregation. The nature of the work of chaplains of other denominations was ascertained by correspondence and phone conversions. 
Newspapers such as The Ghanaian Times, The Daily Graphic, and The Weekly Military Bulletin were used as sources for information about the military. Seventh-day Adventist literature dealing with chaplaincy served as source material. Research was accomplished in general literature dealing with chaplaincy ministries in the United States Armed Forces. From this research, a manual was developed to guide future Seventh-day Adventist chaplains in their functions in the Ghana Armed Forces. The manual contains the following:

1. Seventh-day Adventist expectations of Adventist chaplains in the Ghana Armed Forces

2. Ghana Armed Forces expectations of Seventh-day Adventists

3. How to evangelize in the armed forces, including healthful-living seminars and marriage seminars.

\section{Limitations of the Project}

This project is limited to the Ghana Armed Forces, but it is meant to benefit the Seventh-day Adventist members in other countries of Africa as a whole as it relates to the establishment of military chaplaincy.

\section{Expectations of the Project}

The expectations of this project are:

1. To suggest ways of establishing a seventh-day Adventist Chaplaincy Ministry in the Ghana Armed Forces 
2. To enable the Africa Indian Ocean Division to better support the establishment of Seventh-day Adventist Chaplaincy Ministry in the Ghana Armed Forces

3. To serve as a model for the establishment of Seventh-day Adventist chaplaincies in the military forces of other countries in the Africa Indian Ocean Division

4. To develop a manual to guide future seventh-day Adventist chaplains in their functions in the Ghana Armed Forces.

\section{Methodology}

The study is both descriptive and suggestive. Interviews and research into books and the Ghana Armed Forces communication sources were used to gather information and suggestions to establish Seventh-day Adventist chaplaincy ministries in the Ghana Armed Forces. 
CHAPTER II

THEOLOGICAL BASIS FOR MILITARY CHAPLAINCY

\section{The old Testament}

War is a reality in the old Testament. The reader is forced to notice that the everyday life in OT times involved war, worship, and work, all of which require a chaplain.1 In oT times, the priests, prophets, and patriarchs acted as military chaplains.

The ultimate purpose of the OT is to help people to know God and His plan of salvation. It helps us, therefore, to realize that although humanity is limited by sin, which frequently results in war, God is not limited, nor is His plan of salvation. God has worked to save mankind during peace and war through His patriarchs, priests, and prophets.

In Gen 14, when Lot was taken prisoner at the battle of four kings against five, Abraham rescued Lot from the army of the four kings. As a military commander and spiritual leader, he organized and trained his 180 servants. ${ }^{2}$

${ }^{1}$ Margaret Embry, Everyday Life in Biblical Time: Work, Worship and War (Nashville: T. Nelson, 1994), 1

${ }^{1}$ The four kings were Amraphel, king of Shinar; Arioch, king of Ellaser; Chedorlaomer, king of Elam; and Tidal, king of Nations. The five kings were Bera, king of Sodom; 
Abraham is the only patriarch to appear in the role of a military leader. He lost no time in making preparation to rescue his nephew, but set out in pursuit immediately. ${ }^{1}$

As a commander, he fought to deliver his nephew from the four kings; as a chaplain, he performed his religious duties and offered tithe of all he got to Melchizedek, who also acted in the role of a priest and chaplain when he blessed Abraham, the victorious commander.

simeon and Levi committed mass murder of the Shechemites in Gen 34 because of the rape of their sister Dinah by Shechem, the son of Hamor the Hivite, prince of the country. Jacob acted as a chaplain, rebuking his children of their evil deeds. He taught them that the just cause of anger is not an excuse for evil and inhumane action. Even the rape of their sister did not merit that kind of action. He taught his children that patience under injustice merits divine approval.

The fact that the patriarchs acted as chaplains in war seems to contradict individual philosophical opinions on war as a reason for not establishing military chaplaincy. Thus, views for or against the justice or injustice of war do not, in principle, argue against military chaplaincy. We need to provide spiritual help and guidance to men and women in the

Birsha, king of Gomorrah; Shinab, king of Admah; Shemeber, king of Zeboiim, and Zoar, king of Bela.

"Genesis," SDA Bible Commentary, ed. F. D. Nichol (Washington, DC: Review and Herald, 1953-57), 1:306. 
military. We also need to simply recognize the spiritual needs of military personnel without actually endorsing war as a means of settling international dispute. Military persons and their families who participate actively in the defense of their country must be given opportunity to hear the good news of salvation brought to them through chaplaincy ministries.

A clear chaplain-type ministry was seen in Moses.

Moses was the first to perform a chaplain-like function when, at Rephidim, as Joshua commanded the "troops" against the Amalekites, Moses kept their morale high interceding with God with his hands raised high. Aaron and Hur had to help support his arms; because whenever his arms sagged the battle turned against Israel (Exodus $17: 18-13)$. $^{1}$

Moses, by raising his arms above his head, infused the army of Israel with the spirit of the Lord, thus ensuring victory over the Amalekites. Moses was a strong military leader of Israel who strongly believed in the mighty power of God, who he described as the "God of war," and a Great Warrior (Exod 15:3-9; Num 21:14; Judg 2:2-9; Num 31:1-31). He was also a spiritual leader, a chaplain concerned primarily with the spiritual well-being of God's chosen nation. The revelation of the blowing of the trumpet in battle was given to Moses. Commentators are of the opinion that in Num 10 the blowing

'James J. North, Jr., Chaplaincy Ministries: The Development and Implementation of a course in Specialized Ministries as Vehicles for Seventh-day Adventist SelfUnderstanding and Expression of Mission (Berrien Springs, MI: Andrews University Press, 1988), 71. 
of the trumpet in wartime brought Israel's needs to God's remembrance, thus ensuring victory. Abercrombie explains Num 10:9-10:

Yahweh commanded Moses to make two trumpets of beaten silver, to be used among other things as a battle signal. "And if ye go to war in your land against the enemy that oppresseth you then ye shall blow an alarm with the trumpets: and ye shall be remembered before the Lord your God and you shall be saved from your enemies" (Numbers 10:9). The signal of the trumpets, it must be added, was not to be given by Moses himself, the Israelites' political-military leader. Instead, it fell by Yahweh's command to the Aaronite priests by "a rule binding for all time."1

The Midianites, at the suggestion of Balaam, had led Israel to grievous sins of fornication and adultery that resulted in a plague from God upon His people. Phinehas, great-grandson of Aaron, solely acted in standing for God by killing an Israelite and the Midianite woman with whom he slept. This action halted the spread of the plagues, and this intercession made him a chaplain. Because of this incident, the Lord commissioned Moses to organize a military expedition to punish the Midianites (Num 25:16-18). Moses sent one thousand of every tribe and Phinehas the priest to the war with the holy instruments ${ }^{2}$ and the trumpets to blow

${ }^{1}$ Lawrence L. Abercrombie, The Military Chaplain (London: Sage Publications, 1977),31-33. He also believes that although little is said about the role of the priest or prophet in battle, a biblical pattern was set on which the role of a chaplain could later be built. This was reinstated during the reign of Saul (Num 31:5; Isa 13:10-14, $2 \operatorname{chr} 13: 12-20$ ).

${ }^{2}$ According to the Bible, the holy instruments are Urim, Thummim, and the Ark of the Covenant (Josh 6:1-6). 
in his hand. We are not told whether Phinehas went as commander of the expedition or went in his role as chief Priest, but we know that this grandson of Eleazer the priest was there as a chaplain (Num $31: 1-6)$.

The Bible makes it clear that religious functions of the military were carried out both by military leaders and religious leaders. Thus, the functions of chaplaincy in the OT were established.

Joshua is seen as a military commander and sometimes as a chaplain. As a commander, God instructed Joshua on how to besiege the city of Jericho. Josh $6: 1-4$ reads,

Now Jericho was straitly shut up because of the children of Israel: none went out, and none came in. And the Lord said unto Joshua, See, I have given into thine hand Jericho, and the king thereof, and the mighty men of valor. And ye shall compass the city, all ye men of war, and go round about the city once. Thus shalt thou do six days. And seven priests shall bear before the ark seven trumpets of rams' horns: and the seventh day ye shall compass the city seven times and the priests shall blow with the trumpets.

As a chaplain, when the Israelites were smitten at Ai, Joshua prayed to God for his people. As a chaplain he reproved Achan of his sin by carrying out the will of God (Josh $7 \& 8$ ). He led the Israelites to war and pleaded for them when they sinned. In Josh 6 , the priests of God went to war by blowing the trumpets continuously according to God's command, until Jericho fell. The work of a chaplain is seen here as carrying out the will of God in battle (Josh $6: 4,6,12-16)$ 
Concerning women as chaplains, it is interesting to note that Deborah, the prophetess, judge, and spiritual leader of Israel, directed the battle against Jaban, the king of Cannaan, and his captain, sisera. Barak was Israel's military commander during this war. God's use of women as chaplains is seen in this battle and in the song of praise that follows in Judg 4 and 5 .

When the Philistines fought against Israel, samuel did not cease to lift up his people to the Lord for deliverance from the enemy. This reveals that one aspect of the chaplain's work was to pray for his people's spiritual and physical deliverance from oppression. When the Israelites rejected Samuel in favor of a king, God continued to use the prophets and priests to work as chaplains for His people. The books of Samuel, Kings, and Chronicles show that the wise king usually relied on the advice of the prophet and priest of Israel (1 Sam 7:7-12; 13:13, 14;4:14-11; 23:6-14; $30: 7,8)$.

It is interesting to note that after David escaped from Saul to the cave of Adullam, "everyone that was in distress, and everyone that was in debt, and everyone that was discontented, gathered themselves unto him and he became a captain over them" ( 1 Sam 22:2). One thing was missing, a chaplain, so the Lord brought Abiathar the priest with Urim and the Thummim (1 Sam 23:6). 
In times of war, David made sure that he inquired of the Lord. David is considered the king who made full use of religious leaders as chaplains at all times ( 1 Sam 30:6-8; $2 \operatorname{Sam} 2: 1$ ).

It is fair to conclude that in the old Testament, the priests and prophets served as chaplains during times of war.

\section{The New Testament}

In the New Testament, Christ told His disciples to go and preach to all nations, baptizing them in the name of the Father, the Son, and the Holy Ghost (Matt 28:19-20). He also predicted that the Gospel of the Kingdom would be preached to all people before the coming of the Lord (Matt $24: 14)$. This commission does not limit itself in any way. It includes all people who have ever lived in this world. John the Baptist could well be first in the NT consulted as chaplain to the military. When John started his ministry, soldiers seeking salvation came and asked: "And what shall we do?" (Luke 3:14). John said: "Do violence to no man, neither accuse any falsely, and be content with your wages" (Luke $3: 18) .^{1}$

1"John," SDA Bible Commentary (SDABC), ed. F. D. Nichol (Washington, DC: Review and Herald Pub. Assn., 1953-57), 5:718. Here, it suggests that John was probably preaching in Peraea within the jurisdiction of Herod Antipas and the soldiers who addressed John were probably Jews in the service of Herod. 
The question was asked in all sincerity, Could soldiers qualify for the Kingdom of Heaven? In John's reply, he did not ask them to resign from the military. He did not condemn the military occupation. Rather, he admonished them not to abuse their power as soldiers--a besetting sin of men in control of others--but that they exercise justice and mercy. This admonition can be given to all military people, because military personnel who do not take this admonition seriously may commit atrocities. John's advice is timeless. It is important for all military personnel of all times to adhere to John's counseling and be content with wages and be morally committed to principles.

Thompson wrote about this in Luke 3:14.

The forerunner of Jesus, when approached by soldiers with the question concerning repentance, "And what shall we do?" replied: "Do violence to no man, neither accuse any falsely, and be content with your wages." The misleading translation in the Authorized Version is "violence" from the Greek diaseio. It means "to shake thoroughly; . . . to extort from one by intimidation money or other property." The key word, however, is "content," . . . . Not surprisingly, John the Baptist does not discuss these soldiers' occupation, for it was quite legitimate. Rather, he scolds them for their misuse of their trade. That he had no intention of dissuading them from the profession of arms is obvious; but to be content with their wages was a command. ${ }^{1}$

${ }^{1}$ Parker C. Thompson, The Chaplaincy of the United States Army: A Manual for Assisting Clergy in Making a Meaningful Career Choice (Ann Arbor: University of Michigan Press, 1990), 27. Thompson cited texts that Jesus was not opposed to the military work: Mark 11:12-21; 5:11-13; John 2:15-17; Rev 19:11, 15. 
Both Luke $7: 1-10$ and Matt $8: 5-13$ tell the story of a Centurion (Greek hekatontorchos: commander of one hundred men) ${ }^{1}$ whose faith was described by christ as extraordinary Christ turned to the disciples and the people who followed and said: "I say unto you, I have not found so great faith, no, not in Israel" (Luke 7:9). Concerning Luke 7:1-10, Thompson wrote,

Especially important for this study is that Jesus tacitly acknowledged the rightness of the man's professional calling, by dismissing him with a simple, "Go thy way; and as thou hast believed, so be it done unto thee." Where there appears to have been any condition or relationship hindering an inquirer's relationship with God, Jesus did not hesitate to call for its immediate rejection. Jesus' acceptance of a centurion is telling (Matt 5:29-30, 8:19-22; Luke $18: 22$; John $4: 16-18) .2$

The profession of the centurion was not condemned by Christ. In fact, his ability to relate Christ's power to military command was remarkable. The word of Jesus to the Centurion was as powerful as His presence in the centurion's house. Just as the soldiers under the centurion's command obeyed him without question, so all powers, good and evil, are subjected to christ.

The NT teaches us that Jesus did not condemn the military as a profession. Rather, he commends the faith of those who are faithful. In Luke $23: 47$, it was a centurion

1"Luke," SDABC, ed. F.D. Nichol (Washington, DC: Review and Herald, 1953-57), 5:752.

${ }^{2}$ Thompson, 46 . 
who glorified God at the death of Jesus saying, "Surely, this man is the son of God."

The acceptance of Christ as a personal Savior by military personnel did not cease after the death of Jesus. In Acts 10, the conversion of Cornelius opened the doors of the church to Gentiles. When the time came for the doors to open to the Gospel so it could take root in the Gentiles' heart, the Lord used a military officer who was consecrated to His cause. Cornelius, the centurion, was a just man, one who feared God and was of good report among all the nations of the Jews. Such people are in the armed forces, and the Lord uses the military chaplaincy to shepherd them. In fact, Peter could be considered as Pastor "chaplain" to Cornelius.

Consider what took place in Acts 10 . One must agree with an observation made in the pulpit commentary. It states:

God is not a respecter of persons should be the motto of every Christian ambassador, whether in carrying the message to the degraded classes of our own population or to the healthier. One Gospel for rich and poor, cultivated or uncultivated.

There is one gospel for civilian and military personnel. God's estimate of man is universal, His opinion of people is His own; in God's eyes, the blood of the poor

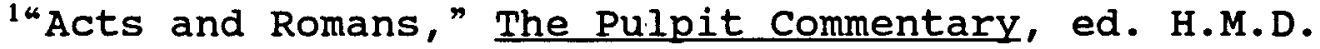
Spence (Grand Rapids: Wm. B. Eerdmans Pub., 1977), 18:346.
} 
is of the same color as of the rich, social distinctions have no weight with God. ${ }^{1}$

Hence, in dealing with the Gospel Commission, all Christians must remember that all men are God's children and must be given equal opportunity to accept or reject christ Jesus as their personal savior without respect to their cultural, educational, social, ethnic, or employment status. ${ }^{2}$ Military personnel are not beyond the reach of the Gospel; hence, there is a need for military chaplaincy. The conversion of Cornelius is second only to the conversion of Paul in the book of Acts. It is a pivotal point in the development and expansion of the church. In fact Cornelius was the first Christian convert in a Gentile home and the first missionary (he gathered friends and family to hear Peter and many of them became believers too!).

Paul served on many occasions as a chaplain to military personnel when they were guarding him. ${ }^{3}$ During Paul's imprisonment, he preached to some soldiers in Caesar's household and they were converted (Phil 4:22, 2 Tim 4:20-21, $20: 12$.

'Ibid., 346. See also 2 Cor 1:26; Job 34:19; Rev 11.

${ }^{2} \mathrm{Gal} 3: 28$; Col $3: 10,11$; Matt $22: 16$; Jas $2: 26$; Rom 2:9-

${ }^{3}$ Acts $21: 30-32 ; 23: 20-23 ; 27: 42-44$. 
Rom 16). ${ }^{1}$ Because Paul's heart was fixed to serve God, he found the opportunity to witness for Him.

E. G. White wrote concerning Paul's final act:

Paul was taken in a private manner to the place of execution. Few spectators were allowed to be present; for his persecutors alarmed at the extent of his influence, feared that converts might be won to Christianity by the scenes of his death. But even the hardened soldiers who attended him listened to his words and with amazement saw him cheerful and even joyous in the prospect of death. To some who witnessed his martyrdom, his spirit of forgiveness toward his murderers and unwavering confidence in Christ till the last, proved a savor of life unto life. More than one accepted the Savior whom Paul preached, and for erelong fearlessly sealed their faith with their blood.2

A centurion saved Paul from a execution during the shipwreck (Acts 27:1-44). Thus military personnel are also agents of salvation.

Paul, therefore, in his final act brought military personnel to the Gospel. Later, as Mrs. White relates above, these military persons were not afraid to die for their Creator and Savior.

\section{Summary}

Both the old and the New Testaments are concerned with motives of chaplaincy ministries as a means of salvation to all kinds of people without respect to their job or profession.

${ }^{1}$ Ellen G. White, Acts of the Apostles (Washington, DC: Review and Herald Publishing Assoc., 1974), 463, 465-466.

${ }^{2}$ Ibid., 509, 510 . 
God used the patriarchs, prophets, and priests to perform chaplain-like functions in the old Testament. In the New Testament, no condemnation is given to military personnel because of their duties. Rather, they are warned to be careful how they exercise their power. John the Baptist, Jesus, Peter, and Paul all ministered to military personnel. They accepted them and their profession without rebuke while ministering to their need. It is important that the Seventh-day Adventist Church also continue to minister to military personnel. For Ellen G. White's and the Seventh-day Adventist view on military service see Appendix E. 
CHAPTER III

SEVENTH-DAY ADVENTISTS AND THE GHANA ARMED FORCES

\section{A Short History of the Ghana Armed Forces}

Before the Gold Coast, presently Ghana, became independent in 1957, it was ruled by the British who colonized the country for almost two centuries. The Gold Coast Regiment was the forerunner of the present Ghana Armed Forces. The British commissioned the regiment in 1897 . It consisted of sixteen European officers and 1,203 Africans. In 1901, the British, which were ruling Gold coast (now Ghana), gave it official legal recognition and changed its name to the Royal West African Frontier Force (WAFF). By 1901, it had thirty officers and 650 personnel in other ranks.

By 1906 , it had been re-organized as a battalion of eight companies and a battery. ${ }^{1}$ The headquarters was in

${ }^{1}$ A. Haywood and F. A. S. Clarke, The History of Royal West African Frontier Force (Aldershot: Gale and Palden, $1964), 7$. 
Kumasi which had four companies and the battery. ${ }^{1}$ The other four companies were stationed in Accra, Mampong, Nkoranza, and odumasi. It is not surprising that the headquarters was in Kumasi because the main reason why the British formed the Gold Coast Regiment was to stop the Ashantis, who had been fighting against the British for more than seventy years. In their quest to stop the British from colonizing them, the Ashantis fought the British and five times succeeded in driving them from their territory.

In 1911 the British, sensing the Germans' intention of war, increased the Royal West African Frontier Force from 7,200 to nearly 30,000. By 1920, when the British sensed peace and no threat from other countries, the Royal west African Frontier Force was reduced to one infantry battalion with the headquarters still in Kumasi. The stations of the other regiments were in Tamale, Accra, and Kintampo. The number of Gold coast men in the Royal West African Frontier Force, however, increased to its peak during the second World War and, by 1945, there were 63,038 men (three battalions) of whom 41,888 had served overseas. During the war, the British established the wartime Royal West African

${ }^{1}$ Battery: an emplacement where artillery is mounted (a fortress); an entire armament of a warship's guns. The basic tactical and administrative artillery unit usually consisting of from two to six pieces with the necessary personnel, transportation, communications, and equipmentcompare a company. Webster's 3rd International Dictionary (1986), s.v. "Battery." 
Training School at Teshie, near Accra, to ensure common methods of training throughout their colonies worldwide.

Until 1953, this training center was known as the Command Training School. The course was given the name Cadets Cadre course ( $\mathrm{CCC}$ ). After graduating, the best students then proceeded to Eaton Hall, Chester, in England, while the remaining graduates stayed and worked in Ghana. In 1953, the scope of the training at Teshie was widened and the school was renamed the Royal officers special Training School (ROSTS). This training school still exists, although with a different philosophy, and continues to be a training ground for officers in the present Ghana Armed Forces. Its present name, Ghana Military Academy, was given to it in April 1960.

Soon after the Second World War, one of the Gold Coast wartime battalions was disbanded, leaving two. However, the third battalion was restored, after the civil disturbance in 1958. When Gold Coast became Ghana in 1957, the military establishment was headed by Major-General A. C. Paley. He had been appointed in May 1954 and stayed in Ghana until July 1960. Of the 238 officers under.his command, 208 were British and 29 were Ghanaians. There were also 230 Warrant officers and staff sergeants.

Joseph Ankrah, who was among the first eight enlisted Africans to have a rank in the Royal West African Frontier Force, became sergeant in 1947. He rose to become the 
Deputy Chief of Defense Staff in the early 1960s and was dismissed by President Kwame Nkrumah in 1965. However, in 1966 he made a comeback as a Chief Defense Staff and chairman of the Army-Police National Liberation Council.

\section{Composition of the Army}

The northern soldiers of the Royal West African Frontier Force formed 80 to 90 percent of the armed forces until 1945. They were mostly from Mamprusis, Fra-Fra, Mossis, Gonjas, and Dagombas. Since schools in those days were mostly in the coastal and Ashanti regions, these men had no education. Because of the lack of education of these men who first joined the army, the army until recent years was ranked at the bottom of the list of such professionals as medical doctors, university lecturers, lawyers, chief auditors, secondary-school teachers, clergymen, businessmen, nurses, politicians, and civil servants. The only jobs rated lower than the army officer were policeman, farmer, car mechanic, middle-school teacher, and street cleaner. Until the 1970s an army career came very low in the students' hierarchy of career aspirations. Officers in the army were regarded by the civilians as "small boys."1

'Simon Baynham, The Gold Coast Military Force: Origins, Composition and Structure (Pretoria: African Institute of South Africa, 1994), 6,7. 
It should be noted that before independence, there were no university graduates from Ghana in the armed forces. 1 The low opinion of the military establishment began to change after 1966, when the army successfully overthrew Kwame Nkrumah's government. At this point, the army gained political strength.

Even now, in the eyes of most middle-aged Ghanaian men and women, the armed forces is considered to be infected with tribalism, bribery, lies, corruption, inefficiency, inactivity, sectionalism, tyranny, thievery, and is poweroriented. The Ghana Armed Forces has consistently tried to improve its image. The civilian population is now accepting and identifying with it. Improving this relationship is an ongoing process and must not be halted. ${ }^{2}$

The Ghana Armed Forces and Politics

Although most of the people who first joined the armed forces were uneducated, they took advantage of educational opportunities offered by the armed forces leadership. This prepared them to be well educated not only in things

${ }^{1}$ Haywood and clarke, 8-10.

${ }^{2}$ Ibid. , 9, 10 . 
concerning their profession and their country but also in politics, economics, and world affairs. These are facts known only by well-educated civilians.

It was, therefore, not surprising that when the Conventional People's Party (CPP) with authoritarian concepts established a one-party state in February 1964, the army command objected to it. It also objected to the creation of a separate Presidential Defense Guard. It was able to stage a coup on February 24, 1966, and overthrew Dr. Kwame Nkrumah, installing an army-police regime.

This was the first act of the Ghana Armed Forces in asserting its power to rule the country. From that time till 1992, Ghana had been ruled by a variety of armed forces personnel who seized power through force and ruled by force. ${ }^{1}$

\section{Religious Rights of the Ghana Armed Forces Personnel}

In the United States, it is both a constitutional and legal right of every citizen to practice his/her religious belief without interference from the government. The First Amendment to the United States constitution states:

\footnotetext{
${ }^{1}$ There have been only two civilian governments before 1992: these are the Busia regime, which lasted for two years, and the Limman regime, which lasted for almost a year.
} 
"Congress shall make no law respecting an establishment of religion or prohibiting the free exercise thereof."1 Military persons are included in the free exercise provision so that wherever they are sent in the world they must have the right to practice the religion of their choice. The fourteenth ammendment of the United States Constitution, section one, states:

All persons born or naturalized in the United States, and subject to the jurisdiction thereof, are citizens of the United States and of the State wherein they reside. No state shall make or enforce any law which shall abridge the privileges or immunities of citizens of the United States; nor shall any state deprive any person of life, liberty, or property, without due process of law; nor deny to any person within its jurisdiction the equal protection of the laws. ${ }^{2}$

Thus, according to the constitution, the government in the person of its military must give equal protection to the various forms of religious practices. The employment of a variety of chaplains who are responsible for worship services consistent with their own denominational beliefs is a fulfillment of the fourteenth amendment. The use of chaplains in the Armed Forces protects the religious expression of the personnel.

In Ghana the constitution allows freedom of worship without parliamentary interference. Hence, it is the legal

${ }^{1}$ Leo Pfeffers, preface to Religious Freedom (Chicago: National Textbook Company, 1987), vi.

${ }^{2}$ Joseph B. Junes, The Ratification of the Fourteenth Amendment (N.P.: Mercer University Press, 1984), 289-290. 
and constitutional right of all Ghana Armed Forces personnel to practice their own religion. Thus the Ghana Armed Forces chaplaincy department oversees that each person in the armed forces enjoys that freedom.

\section{Seventh-day Adventists in the Ghana Armed Forces}

The only known Seventh-day Adventists in the Ghana Armed Forces before 1970 were Major Kwasi Akomeah and Major Emmanuel Robert Damson. Until the late 1970s, therefore, the Seventh-day Adventist Church was not known by the Ghana Armed Forces. Until that time, the traditional Ghanaian concept of the Ghana Armed Forces made it very difficult and very unlikely that Adventists would join the armed forces. The policy guidelines of the Ghana Armed Forces Chaplain General's Department, specifically section A, reads: "Any religious body with 1000 (one thousand) service personnel belonging to it shall be given official recognition to enable the said body to operate as a church, etc., in the Armed Forces."1 This criteria made the Seventh-day Adventist Church an unrecognized religious body in the armed forces.

This unknown face of Seventh-day Adventists and its relationship to the Ghana Armed Forces changed in the late

${ }^{1}$ Ghana Armed Forces Communication (GHQ/14022/RA), "Recognition of Religious Bodies in the Armed Forces," Chaplain General's Department, General Headquarters, Ghana Armed Forces, Burma Camp, Accra, December 1970. 
1970s when some senior and lower-ranked armed forces personnel became Adventists.

$$
\begin{gathered}
\text { History of the Establishment of } \\
\text { the Adventist Congregation }
\end{gathered}
$$

By 1983, about one hundred Seventh-day Adventist soldiers were in the Ghana Armed Forces. These military personnel, their families, and some civilians working with the armed forces in Burma Camp, Accra, were worshiping in various places. They were principally worshiping in three locations in Accra, namely, Labone, Accra New Town, and Hanson Road. Considering the distance and their unique needs, they decided to form a branch Sabbath School in Burma Camp.

The first Sabbath School meeting in Burma Camp took place on January 1, 1984, in a classroom at Chiringa Barracks. Twelve people were present. The meeting was led by Carl Ahiable, Safo Adu, and oppong Boakye. Members of this group immediately began house-to-house visitation, inviting Adventists and non-Adventists to their meetings. As a result of their visitation, Adventist backsliders came out openly to join the group. Dawn broadcasts and all-night prayer meetings also were held. ${ }^{1}$

In the latter part of 1984 , this new church was fortunate when two higher-ranking officers, Lt. Col. Opuni-

${ }^{1}$ Isaac Buabeng, Short History of Burma Camp Seventh-day Adventist Church (Accra: Barracks Press, 1993), 1. 
Mensah, who became a Seventh-day Adventist in Kumasi, and Lt. Col. Buabeng, who was a church elder in Labone, joined the membership. Those two officers sought permission from the armed forces headquarters to have a three-week evangelistic crusade conducted under an open-air tent. Permission was granted on April 17, 1985. ${ }^{1}$

Pastor Andrews L. Ewoo, assisted by a team from Kumasi Amakom SDA Church, and Djmi Abra, with Elder Asafo Acheampong from Madina Church, successfully conducted this evangelistic campaign. One hundred and five men and women in the Ghana Armed Forces were baptized. This new, growing group continued to worship in a classroom at chiringa Barracks until February 1986, when a directive came from the armed forces headquarters that all religious activities should be held in designated places of worship and not in classrooms. The group immediately sought permission to worship lawfully at Burma Camp in a recognized place of worship. This request was granted by the chaplaincy service directorate of the Ministry of Defense. ${ }^{2}$

The letter, dated May 6, 1986, was received by the Seventh-day Adventist Church on June 11, 1986. It confirmed the right of the SDA group to meet at the Arakan chapel on Wednesdays, Fridays, and Saturdays; the other churches were

${ }^{1}$ Ibid. , 2 .

${ }^{2}$ See Appendix A for full text of the letter. 
assigned to other days. This new group was established and protected by the living God. In a humble way, it enriched the camp not only spiritually but also physically and socially. The group carried out many programs which helped to increase its own membership and to establish other congregations in Sunyani and Takoradi. Programs sponsored by the group were:

1. Sponsorship of a team of five medical doctors to give free public-health lectures and counseling on diabetes, hypertension, family planning, dental care, and diet (This program ran June 6-29, 1990.)

2. A one-week educational program about the dangers of smoking and how to stop smoking in five days

3. A tree-planting program at the Gongo Junction to improve the environment

4. Six months of volunteer work to promote sanitation in the camp by disinfecting all drains in 1988

5. A visitation program to donate food items to the orphanage Village in Legon, the deaf and mentally retarded people in Dzorwulu Special School, and prison inmates in Accra and Nsawam (Medical supplies and food items were also donated to the children's ward in thirty-seven military hospitals.)

6. A full-scale house-to-house, personal evangelism program within the various army barracks around the country, especially sunyani and Takoradi. 
The increase in membership did not go unnoticed by the enemy. The church suffered a period of distress and instability resulting from an order to stop meeting, which is described below. A philosophical distress came upon the church from the enemies outside the church, who saw the increase in membership as a threat to their own churches' existence.

\section{Problems Encountered by Seventh-day} Adventists

The Chaplain General's office wrote a letter in December 1990 ordering all church groups in the armed forces, including all Adventist groups, to close down. ${ }^{1}$ Along with this general letter came a more specific letter addressed to the Seventh-day Adventist Church ordering members to stop worshiping in the military barracks. ${ }^{2}$ The Seventh-day Adventist church ceased worship services in the Arakan Chapel and Burma Camp in Accra on 5 January 1991, but the church members did not cease to pray. They believed that their records were in order and did not understand why this order should affect them.

They presented a petition to the Armed Forces General Headquarters on 21 January 1991. Since they received no

\footnotetext{
${ }^{1}$ See Appendix A.

${ }^{2}$ See Appendix A.
} 
response, they sent a second petition on 9 January 1992. This time they made specific requests which included:

1. Permission to continue worshiping in the barracks

2. Permission to erect a chapel

3. Authorization for the parent church to continue to provide an ordained pastor to minister to the spiritual needs of the Adventists until the armed forces could assume full responsibility.

The petition reflecting the determination of the Seventh-day Adventist group in Burma Camp was a passionate appeal to the Ghana Armed Forces Chief of Staff for recognition. ${ }^{1}$ Together with prayers and fasting, this strong petition was granted by the General Headquarters of the Ghana Armed Forces on 25 August 1992, one and a half years after the first petition was mailed. The letter granting the petition included three instructions.

1. The Seventh-day Adventist group is officially recognized to operate as a church in the armed forces.

2. The appropriate instructions are to be issued to enable the church to use one of the garrison churches for worship on Saturdays.

${ }^{1}$ See Appendix A. 
3. The application for a plot of land is being considered. ${ }^{1}$

One petition was written on behalf of all the Adventist groups in the Ghana Armed Forces. The Burma Camp SDA group, like the other SDA groups in Kumasi Barracks, Takoradi Barracks, Sunyani Barracks, and Tamale Barracks, stood firm for Christ. Their bravery, prayers, faithfulness, commitment, and foresight in writing appeals to the chaplain General about his initial order resulted in a reversal of his decision and gave permanent acceptance for the seventhday Adventist denomination in the Ghana Armed Forces.

Now the Seventh-day Adventist Church is among the seven religious bodies that is recognized by the Ghana Armed Forces. The church, therefore, has potential for growth, and has every reason to be grateful to God for His intervention.

\section{Potential for Growth}

More than three thousand Seventh-day Adventist military personnel and their families are now in the Ghana Armed

\footnotetext{
${ }^{1}$ See Appendix A.
} 
Forces in various barracks across the country. ${ }^{1}$

In June 1994, Ghana had a total of 11,850 military and paramilitary personnel (Army, 5,000; Navy, 850; Air Force, 1,000; Paramilitary, 5,000). The armed forces budget was 20,700 million cedis $\left(\$ 207\right.$ million).$^{2}$ The Seventh-day Adventist Church has a few, very influential people in the higher ranks of the armed forces.

The church has been offered land in Burma Camp in Accra to build a church. Members have been raising money and are still raising money while the church is being built. Presently (1998), a civilian pastor, who is taking care of ten other large churches, is in charge of the Burma Camp SDA Church with its 860 members. It is expected that the church will continue to grow when a Seventh-day Adventist chaplain with a rank of a military officer is appointed to take full responsibility.

The Adventist Chaplaincy Ministries of the General Conference of Seventh-day Adventists donated $\$ 1,500.00$ to the church in Ghana. This was a contribution to purchase a piece of land for church building and establishment of

${ }^{1}$ According to the military hiring records in the Ghana Armed Forces Personnel Department, active duty Seventh-day Adventist military personnel in the Ghana Armed Forces now number 652 .

"Defense--Ghana, Introductory Survey," The Europe World Yearbook (London: Europa Publication, 1995), 1:1331. 
chaplaincy ministries at Burma Camp, Ghana. ${ }^{1}$

The armed forces authority has requested the Seventhday Adventist Church to recommend and appoint at least four Seventh-day Adventist chaplains to the force to be responsible for religious needs of Seventh-day Adventists in the armed forces. It is hoped that the church will grant this request. The potential for growth in this youthful, well-respected Seventh-day Adventist military environment is in itself a strong indication of the church's readiness to carry the gospel to non-Adventist military personnel if good leadership is provided through chaplaincy ministry.

\section{Seventh-day Adventist Attitudes Toward Military Chaplaincy}

The seriousness of the attitude of seventh-day Adventist military personnel toward the military chaplaincy could be sensed from a letter written by the Burma camp Seventh-day Adventist Church to the office of the Director of Religious Affairs in the Armed Forces Headquarters 21, January 1991. In this letter the church requested the Ghana Armed Forces to provide them with a chaplain.

In conclusion, your humble petitioners request to state that . . . we be provided with a chaplain to promote the moral and spiritual welfare of the Adventist

${ }^{1}$ Richard 0 . Stenbakken, Director of Adventist Chaplaincy Ministries of the General Conference of Seventhday Adventist, telephone interview by author, January 8, 1998. 
Service personnel and our families. ${ }^{1}$

The South Ghana Conference has provided the Burma Camp, Takoradi, and the SDA military barracks churches with a civilian pastor who already is responsible for eight to twelve civilian churches.

Several reasons probably limit civilian Seventh-day Adventist pastors from accepting an active-duty commission in the Ghana Armed Forces. Some of them are:

1. About 98 percent of Seventh-day Adventist military personnel became Adventists when already in the armed forces. The present unemployment rate and job security in the Army basically prevents them from leaving the services. The Army offers job security, whereas going to an Adventist college to study theology to become a chaplain and not knowing what the family will eat during those four years presents a big risk.

2. The old view of the Ghana Armed Forces as a brutal force which takes by force what does not belong to it and as oppressors of the poor prevents Adventists from considering the armed forces as a career. Though this condition no longer exists, this view still lingers in the minds of Adventist ministers who might consider military chaplaincy as a lifetime career.

${ }^{1}$ Seventh-day Adventist Church to office of Religious Affairs, Ghana Armed Forces Headquarters, Points 30, Division D, Accra, Ghana, 1991. See Appendix A. 
3. The lack of pastors in Ghana as a whole makes the demand for pastors very high; hence, none has been willing to take the military work.

4. Past history of the Ghana Armed Forces has shown that most high-ranking officers were arrested and beaten during coup attempts and successful military coups. Hence, Adventist individuals do not see the need of going to college to end up being abused during another coup which is still considered by some as a risky job, even though the Conference would likely not stand in the way.

5. Most Adventists, because of their lack of knowledge about the Ghana Armed Forces, are not aware of the financial benefit for taking such a responsibility.

6. Students in theology get no encouragement from Adventist ministers and teachers in theological programs from the conference about the need for making a decision to become a chaplain in the armed forces. Hopefully, this attitude will change as more Adventists come in contact with the armed forces and Adventist ministers consider military chaplaincy as a meaningful career.

8. The Conference is willing to allow some qualified pastors to become chaplains in the Ghana Armed Forces but since most of the pastors in Ghana are old, age limits disqualify them. 
Summary

Since its formation in 1897, the Gold Coast Regiment, presently Ghana Armed Forces, has grown in size and numbers. Their bad image has improved. The Seventh-day Adventist Church is not only present but has been accepted and given opportunity to establish its presence by building churches in the various camps. The armed forces have also requested the Seventh-day Adventist Church to supply chaplains to serve Seventh-day Adventist military personnel and their families. These chaplains will also be responsible for the spiritual needs of any military personnel.

The miraculous history of the establishment of Adventist congregations in the Ghana Armed Forces, ${ }^{1}$ the problems encountered by the Seventh-day Adventist military personnel, and the potential for the church to grow in the Ghana military need to be recognized. The church needs to send chaplains to facilitate growth.

For anyone willing to become an SDA chaplain in the Ghana Armed Forces, chapter 4 provides a manual entitled "The Chaplain's Handbook."

${ }^{1}$ The letter of acceptance of the petition is given in full in Appendix $A$. 
CHAPTER IV

THE CHAPLAIN'S HANDBOOK: A MANUAL FOR SEVENTH-DAY ADVENTIST MILITARY CHAPLAINCY

IN THE GHANA ARMED FORCES

\section{Introduction}

This chapter presents a manual which can serve three purposes:

1. It is for Seventh-day Adventist members who are considering serving as chaplains in the Ghana Armed Forces.

2. It is for the Seventh-day Adventist Church in Ghana as it considers sending pastors into the Ghana Armed Forces as chaplains to lead in the establishment of Seventh-day Adventist Chaplaincy Ministries.

3. It is for the Ghana Armed Forces to expand their knowledge as to how the Seventh-day Adventist Church operates.

In connection with the above, this chapter contains military regulations and customs governing the placement of chaplains in the Ghana Armed Forces and explains the status of chaplains, entry prerequisites, promotion, pastoral 
ministries, crisis ministries, and religious program organization. ${ }^{1}$

This manual also contains basic information on the mission, status, functions, and expectations of a seventhday Adventist military chaplain in the Ghana Armed Forces. It also suggests how a pastor should carry out the work of a chaplain and evangelist in the Ghana Armed Forces. A brief outline of healthful living and marriage seminars is given. It also contains issues that affect Seventh-day Adventist military such as combatancy and diet.

\section{Military Regulations and Customs Governing the Placement and Functions of Chaplains}

Status of Chaplains: Entry Prerequisites

To qualify for an appointment as a chaplain in the Ghana Armed Forces, the individual must:

1. Be ordained or commissioned by his/her church as a minister with at least a four-year Bachelor's degree in Religion or Theology (a person with a Master of Divinity or Master of Arts in Religion degree is preferred)

2. Meet the physical requirements set forth by the

${ }^{1}$ Undocumented material regarding the Ghana Armed Forces is paraphrased because permission to quote from the Ghana Armed Forces Regulation was refused due to its incomplete status and security classification. In fact, the ChaplainGeneral department believes that the writing of this paper will help in the formation of their manual. Because of the close alignment of the Ghana Armed Forces and United States Chaplaincy regulations, quotations are made from the United states Army Chaplain's Manual. 
Ghana Armed Forces including the Medical Health Test

3. Be a citizen of Ghana either by birth or naturalization

4. Be under forty years of age for active duty, preferably under thirty-six

5. Be engaged in the ministry of one's denomination as a full-time vocation.

The chaplain is a clergyman in uniform. He/she represents religion which teaches fortitude, reverence, and justice as well as kindness, sympathy, and humility. ${ }^{1}$ The overall duties of the Ghana Armed Forces chaplain are to promote religion and morality. One contemplating becoming a chaplain in the Ghana Armed Forces must know that this work does not begin and end in the office. Rather, at times, the work may well be around the clock.

\section{Chaplain Duties: Pastoral Ministries}

Duties and ministries of chaplains include:

1. Accepts opportunities for public and private worship consistent with the religious beliefs, customs, and practices of the military personnel, their dependents, and authorized civilians as long they do not conflict with the chaplain's denominational beliefs

2. Acts as an adviser and consultant to the commander

${ }^{1} \mathrm{U} . S$. Department of the Army, The Chaplain, Field Manual 16-5 (Washington, DC: Headquarters, Department of the Army, 1977), 1-2. 
and his staff in all matters which pertain to religion, morals, and morale as affected by the mission of the unit

3. Makes provision for proper and appropriate administration of rites, sacraments, and/or ordinances ${ }^{1}$

4. Expects to teach matters relating to his denomination in the Ghana Military Academy.

The duties of chaplain always must be done with confidence in love for the Lord God to whom he/she ultimately gives account. A military chaplain is a pastor, counselor, consultant, adviser, and a human--with human limitations. What enables individuals to perform all these duties is total dependence upon the Lord Jesus Christ.

Seventh-day Adventist chaplains are recommended by the church to the Ghana Armed Forces primarily to help meet the spiritual, physical, and mental needs of seventh-day Adventist military personnel. The Ghana Armed Forces Chaplain General will assign them primarily to meet these needs. Chaplains must know that they represent the church but are employed by Ghana Armed Forces. Hence, at times they must be responsible for other pastoral duties as required by the Chaplain General provided these do not contradict or conflict with their religious beliefs.

${ }^{1}$ Ibid.,2-3. See also "U.S. Department of the Army, Meeting Religious support Requirements" FM 16-1, Religious Support and Doctorine: The Chaplain and Chaplain Assistant (Washington, DC, Department of the Army, 1989), 1-7. 
One of the best summaries of the duties of a chaplain is provided in section XXI, Chaplains of Army Regulation, 10-6. (See Appendix D for the full text.) In addition, a Ghana Armed Forces chaplain serves as a commandant of the Ghana Army Chaplain School and as a member of the staff and faculty of the Service officer's school in Teshi Camp. Individual chaplain assignments are given by the chaplain General in the Armed Forces Headquarters.

No chaplain is required to conduct or participate in any service, rite, or sacrament contrary to the requirements of his/her denomination. ${ }^{1}$

Chaplains seek to provide an opportunity for members of the command to receive the ministrations of their own religious faith in such a way and on such occasions as their denomination requires. If special denominational services are required by denominational law, chaplains of these denominations serving in the armed forces must make the necessary arrangements for members of their own group in the area. $^{2}$

The following rules must be remembered by the chaplain from the Seventh-day Adventist or any other denomination in the Ghana Armed Forces:

The Chaplain's spiritual authority to preach in public, to conduct religious services, to perform ecclesiast-

$$
\begin{aligned}
& { }^{1} \text { Ibid., 3-2. } \\
& { }^{2} \text { Ibid., 3-7. }
\end{aligned}
$$


ical rites, and to administer sacraments and ordinances is obtained in the ordination or commission given him by his church. The ritual and rules of his denomination are consequently his guide in these matters.

A. The chaplain conducts such services, rites, and sacraments as his denomination requires.

B. The chaplain may not be required to conduct any service, rite, or sacrament contrary to the laws and practice of his denomination.

c. The chaplain may officiate jointly in a religious service with a chaplain or civilian clergyman of another denomination unless forbidden by laws and practices of his own denomination. Freedom of worship in one's own denomination's way of life is recognized by the military establishment.

D. Each chaplain will exercise care and objectivity in selecting religious literature for display and distribution in chapel and day room literature racks. Chaplains are free to distribute publications reflecting their own religious orientations which teach the doctrines in a positive manner, being careful to screen out attacks on the beliefs and practices of other religious groups. Chaplains must also insure that literature foreign to this concept is not introduced into literature displays by others.

\section{Chaplain as an officer}

Because a chaplain is an officer but does not hold any command authority, he or she must set a good example in dressing, military courtesy, relationship to other commands, physical fitness, and lifestyle.

\section{Dress}

Since the chaplain is an employee of the armed forces, military uniform rules must be observed. The style of

${ }^{1}$ Ibid. , 3-8. 
uniform, cap, decorations, and color must be in accordance with the uniform theory and practice of the Ghana Armed Forces. Chaplains wear the same uniform as their counterparts. The uniform provided must be washed and ironed." Concerning dress for religious service, chaplains are authorized to wear the uniform, vestments, or other appropriate attire prescribed by ecclesiastical law or denomination practice when conducting religious services. ${ }^{2}$

\section{Military Courtesies}

Military courtesies such as the salute and haircut must be adhered to by the chaplain. Courtesy includes as an essential elements a full and proper appreciation of the rights of others, a special acts and ceremonial procedures. It stimulates harmonious association of individual, smooths the conduct of affairs and adds a welcom note to all manner

${ }^{1}$ For more information about uniforms, see the following: The Visual Dictionary of Military Uniforms (New York: Dorling Kindersley, 1992); Edgar M. Howel, United States Army Headgear, 1855-1902 (Washington, DC: U.S. Government Printing Office, 1975); Francis A. Lord, Uniforms of the Civil War (New York: Thomas Yoseloff, 1970); Paul Brown, Insignia of the Services (New York: Charles Scribner's Sons, 1941); Insignia and Decorations of the Unites states Armed Forces (Washington, DC: National Geographic Society, 1944); Uniform Regulations for the Army of the United States (Washington, DC: Smithsonian Institution, 1961).

${ }^{2}$ U.S. Department of the Army, The Chaplain, 3-8. 
of human contacts, civilian as well as military. ${ }^{1}$

\section{Physical Fitness}

As stated above, to qualify as chaplain in the Ghana Armed Forces, the individual must pass an evaluation for physical fitness. This includes a physical examination on strength and endurance and a review of family health history drugs or alcohol abuse a HIV test, and stress level capacity. Any physical handicap detected at this time will automatically disqualify one from serving as a chaplain.

\section{Relationship to other Commands}

\section{Relationship to Commanders}

For the success of religious programs, the chaplain must be familiar with plans and policies of the command to which he or she is assigned. The commander exercises command over the chaplain as a staff officer. The chaplains must, therefore, render the same type of staff support to commanders of units where chaplains are not assigned as they do to their own commanders. ${ }^{2}$

\section{Relationship to other staff}

The chaplain assumes the responsibility for leadership and direction of the religious program of the command and

\footnotetext{
'Lawrence P. Crocker, The Army Officer's Guide (Harrisburg: Stackpole Books, 1988), 70-89.

${ }^{2}$ U.S. Department of the Army, The Chaplain, 2-15.
} 
serves as senior pastor. Chaplains must understand that they are worshiping together to serve the military community. They do not exercise command. The rule about this reads:

By law (Sec 3581. Title 10, Us Code) a chaplain may not exercise command. The nature and extent of chaplain supervision of the activities in the chaplain's section and in subordinate units depend on command policy. The post or unit standing operating procedures (SOP) must specify the control exercised by the particular staff chaplain. (AR 165-20). ${ }^{1}$

\section{Chaplains and Noncombatancy}

Chaplains are noncombatants. They should not bear arms voluntarily and under no circumstances will they be forced to bear arms. The regulation about this reads:

A chaplain is a noncombatant. As such, his religious duties are limited to those of the noncombatant. He will not be required to bear arms. . . . The 1949 Geneva Convention states that the chaplain will be respected and protected in all circumstances. If captured, the chaplain becomes a "retained person" . . - not a prisoner of war . . and continues his spiritual functions for the benefit of prisoners of war. ${ }^{2}$

Chaplain Promotions

\section{Chaplain as a captain}

Since chaplains are members of the Ghana Armed Forces, they are subject to the rank received by promotion. A new chaplain in the armed forces is generally commissioned as a captain. This first rank could be higher depending upon the

\footnotetext{
I'Ibid., 2-15.

${ }^{2}$ Thompson, 78 .
} 
scholarly degree the person holds and pastoral experience the person has. Here chaplains learn the army routine at ground level. They spend time in physical exercise, field duties, and pastoral work ${ }^{1}$.

\section{Chaplain as a Major}

Basically, after two to four years--depending upon performance--chaplains are promoted to major if they were not hired as a major due to degree and experience. As a major they will be supervisory chaplains responsible for specialized chaplain activities. The chaplain as a pastor will make sure that military personnel, civilian employees, and lay workers work together to care for the church under his jurisdiction.

Training circular No. 16-12 describes the work of a major in this way:

The brigade chaplain is a manager of persons, facilities and other resources. He/she exercises the best leadership skills to insure that individual needs and organizational goals are met. ${ }^{2}$

The brigade chaplain, as Thompson Parker puts it, is a pastor to pastors, as well as the commander's staff officer and advisor on religion, worship, and morale, and the

${ }^{2}$ Crocker, 244-253.

${ }^{2}$ U.S. Department of the Army, "The Supervisory Chaplain Brigade Level," Training Circular No. 16-12 (Washington, DC: Headquarters, Department of the Army, 20 June 1979). 
spiritual leader of soldiers and their dependents. ${ }^{1}$

It must be understood that chaplains are trained in their careers in specialized units in such areas as parachuting, ranger training, jungle martial arts, management, administration, staff work, logistics, and tactics. When successful, this training helps the chaplain to understand and be able to manage the chapel personnel and resources of an army unit. ${ }^{2}$

\section{Chaplain as a Lieutenant colonel}

(Manager)

It is only when this training has been successful and the chaplain has passed all the tests (formal, informal, physical, verbal, and comprehensive) together with appropriate years of experience that he or she is promoted to lieutenant colonel. As lieutenant colonel, the chaplain is responsible for finance, logistics, administration, management, and pastoral and professional development within the field of the chaplain.

Good performance, decision-making ability, dedication, motivation, morale, courage, and the ability to speak articulately and write well are all needed for the chaplain

${ }^{1}$ Thompson, 84 .

${ }^{2}$ Chapel personnel and resources are chaplains, chapel specialists, secretaries, budgeting, and any materials needed by the chaplaincy department. 
to be successful as lieutenant colonel. ${ }^{1}$

Chaplain as a colonel

Experience coupled with continuing education enables the chaplain to be promoted to colonel. Colonel is the highest position a chaplain can attain in the Ghana Armed Forces.

One's longevity in the Ghana Armed Forces and one's ability to participate in higher education enables the individual to rise to the rank of a colonel. The Chaplain General in the Ghana Armed Forces is usually a lieutenant colonel or a colonel.

\section{Crisis Ministries}

Military chaplains must cope with crisis situations for which they may not have been trained during seminary. For example, the chaplain has the responsibility to inform family members that a son or daughter, or husband or wife, is a casualty of war (dead or seriously injured).

The chaplain's ability to counsel is needed when a person is grieving, alcoholic, addicted, violent, abusive, physically ill, choosing a marriage partner, having marital problems, having family problems, involved in divorce, considering remarriage, and having mental disorders.

${ }^{1}$ U.S. Department of the Army, "The Chaplain as Pastoral Coordinator," Training Circular No. 16-11 (Washington, DC: Headquarters, Department of the Army, 1979), 7 . 
Pastoral counseling in these matters is an extension of the chaplain's pastoral care, his or her willingness to listen to the problems and cares of people, and to share with them his or her knowledge and experience. The counseling skill is very important to the success of the chaplain. ${ }^{1}$ In these difficulties the chaplain must have a cooperative relationship with medical personnel in the fields of psychology and psychotherapy, and refer to their expertise.

\section{Coping with Grief}

The chaplain must always remember that grief is very important and, when properly manifested, is the beginning of healing. The basic underlying principle that can help the chaplain to deal properly with grief is how Christ changed the meaning of grief (the meaning of grief was changed from a forever-lost relationship and separation due to death, to a belief in the resurrection of believers). Scripture also demonstrates that, although a Christian knows there is hope for the dead, grieving is normal and healthy ( 1 Thess 4:1317; 1 Cor 15:1-58; John 11:1-57; Job 19:25; Rev 20:4).

At the same time, the chaplain must know that poorly resolved grief can become pathological and unhealthy. The chaplain must know the causes of grief, the intensity of grief, the effects of grief, and how to counsel the

\footnotetext{
${ }^{1}$ U.S. Department of the Army, The Chaplain, 1-3.
} 
grieving. Gary R. Collins suggest ways of counseling grieving individuals.

Encourage discussions about death before it occurs. . . Be present and available. . . Make it known that expressing feelings is good and acceptable, but do not pressure the griever to show feelings; do not be surprised at outpourings of crying, frustration, or withdrawal, still let it be known that you are available and accepting.

Be a careful listener; try not to push. It is best if you make yourself available, be willing to listen and respond when the counselor wants to discuss issues related to grief, but also be willing to back off if the griever wants to talk about something else. Help the grieving person make decisions and gently try to discourage the making of major decisions. Gently challenge pathological or irrational conclusions, then give the grieving person opportunity to respond and discuss the issues. Provide practical help like meal preparation or baby sitting. Do not discourage grieving rituals. Pray for the bereaved and comfort them with words of scripture without preaching or using religious cliches as a means for stifling the expression of grief. ${ }^{1}$

When counseling the family members after the death of Ghana Armed Forces military personnel, the chaplain must bear in mind that, in most Ghanaian settings, the family members solely depend on the military person for financial survival. Grieving can lead to a serious, permanent problem like alcoholism or suicide. The chaplain must encourage talk about the future and discuss practical issues such as raising children, meeting financial needs, dealing with loneliness, and coping with sexual frustration. The

${ }^{1}$ Gary R. Collins, Christian Counseling (Dallas: Word Publishing, n.d.), 357, 358. Collins also believes that when a survivor shows no grief it is possible that the grieving process is being denied or avoided. This can lead to pathological grieving, a condition to be avoided. 
chaplain must help family members explore the possibility of finding a job or involving themselves in trading or farming. since military personnel usually live in military barracks, most family members have no house to return to when the person dies. Here, also, the chaplain can be very helpful if he or she can encourage the army to give the family six months to find a place to live. With an officer aiding the family to place this request, the army usually grants such a request.

\section{Family Problems}

Military families have problems that are usually shared by few others. Hence, a military chaplain tends to be their best source of help.

In the military family, the one who is in the military is gone most of the time, leaving a single parent to care for the children and the extended family who has come to live at the barracks either for education or to search for a job. This situation usually results in a lack of commitment to the family or one member of the family viewing the other as not being committed to the family. This perception leads to despair, frustration, anger, anxiety, or feelings of helplessness.

The Ghana Armed Forces chaplain can best help families by (1) helping them reduce the stress level by not having many children without knowing how to take care of them, being honest about their financial situation by not 
accepting many extended family members in their one-to-twobedroom barracks apartment, (3) teaching families better coping skills, and (4) helping families to have a sense of clarifying roles.

\section{Divorce and Remarriage}

Years ago, in Ghanaian culture, when a man was not satisfied with his marriage, he would marry a second wife. Now society has changed and polygamy is no longer popular in society. In the Seventh-day Adventist church, it is not allowed. This has given rise to divorce, which used to be unheard of in Ghanaian culture. The Ghana Armed Forces chaplain now spends a considerable amount of time dealing with the divorce problem.

A Seventh-day Adventist chaplain, in dealing with divorce and re-marriage of SDAs in the Ghana Armed Forces, must presuppose Seventh-day Adventist beliefs on the biblical teachings on this issue. That is, God intended marriage to be a permanent and exclusive union between a man and woman who find their sexual fulfillment within marriage. Divorce was not recommended in the Bible nor was it encouraged. However, divorce is permissible on two conditions: (1) when one mate is guilty of sexual unfaithfulness (such as incest, child molestation, sexual deviance and (2) when an unbeliever willfully and 
permanently deserts the believing partner. ${ }^{1}$ Even in these permissible conditions the man or woman must seek to forgive unless in certain extreme cases where, against the wishes and efforts of a committed partner, the marriage bond is destroyed beyond any human ability to restore it.

The Seventh-day Adventist chaplain must remember that the church allows the innocent partner in the above permissive conditions to remarry if he/she wishes.

The SDA military chaplain must know that sexual unfaithfulness, desertion, incompatibility, social sanctions, immature attitudes, and persistent stress are the most common causes of divorce in many military personnel homes. ${ }^{2}$

The chaplain does well in remembering that divorce affects people physically, psychologically, and spiritually. It can lead to irrational decisions, interpersonal tensions, anxiety, guilt, fear, sadness, depression, anger, bitterness, confusion, indecision, frustration, and mental illness.

In counseling a family on the verge of divorce, the chaplain must remember that in Ghana when one marries, the

${ }^{1}$ In an instance of physical or emotional abuse and incurable insanity the chaplain should use his/her discretion.

${ }^{2}$ Collins, 453-457. The main causes of divorce in civilian life are also causes of divorce in military life, but in military life abuse and the long-time absence of one partner are the more common causes of divorce. 
whole family is involved. Hence, the family of the two parties must be called to help if the help of the chaplain brings no improvement in the situation.

The following suggestions are recommended for counseling couples considering divorce.

1. Make the biblical position on marriage very clear and emphasize the need of marriage permanence.

2. Help couples admit, confess to God and to each other, and change attitudes that are not helping the marriage.

3. Encourage the couple to avoid belittling, blaming, and criticizing each other.

4. Encourage couples to calm down from vindictive or self-centered hostile ways of relating.

5. Encourage couples to admit and express emotions honestly as they arise.

6. Counsel each spouse to ask what he or she is doing that contributes to the problems in the marriage.

The chaplain must always remember that God hates divorce (the same way He hates $\sin$ ) and that only God can really mend and bind a broken marriage. Hence, couples must seek divine strength, guidance, wisdom, and power separately and together.

Knowledge of God and of each other, persistent commitment, willingness to live in accordance with biblical teaching, and consistent family support, as well as church 
and others can help marriages grow, restore broken relationships, and prevent divorce.

The Ghana Armed Forces Seventh-day Adventist chaplain must know the traditional customs that govern marriage. This enables him to approach marriage in a more traditional way which, like the Bible, seeks to prevent divorce.

\section{Mental Disorders}

Mental disorders that are sometimes found in the general population are also found in the Ghanaian Armed Forces. They include behavior disorders, substance-abuse disorders, sleeping disorders, and others. The chaplain does well to refer the individual to an expert in the field.

\section{Alcoholism}

As in society, most people in the Ghana Armed Forces drink alcohol. This has physical and spiritual effects on the individual as well as the family. Alcoholism usually results in military personnel physically abusing their spouse and children.

In Ghana, the income of most military personnel is not sufficient for the family. The wife/husband has to help support the family. Some carry on a little business, usually by selling clothes or food. If the military member is alcoholic, it brings a major financial burden in addition to the emotional burden to the family. The chaplain tries 
to help by counseling the alcoholic. The following are some suggestions.

1. Get the alcoholic to admit that he or she has a problem.

2. With a physician's help, encourage the alcoholic to stop drinking.

3. Encourage the alcoholic to seek divine help through prayer, letting him or her know that God is the one who can empower individuals to quit drinking.

4. Encourage self-understanding and a change of lifestyle.

5. Counsel the family. Alcoholism affects the whole family, hence, the chaplain is involved with the whole family as a support group for the alcoholic.

6. It is recommended that the chaplain inform the alcoholic so he or she knows the consequence of such a behavior and the reality of the dangers of alcoholism.

\section{Addiction}

Drug dependency, obesity, and behavior addictions are sometimes found in the Ghana Armed Forces. It is the duty of the chaplain to counsel people in these dilemmas. Some suggestions for dealing with people with addiction are:

1. Help the person admit "I can't control drug use."

2. Encourage the counselee to "give up control of his or her life and place it in God's hands." 
3. Guide in self-examination, making sure to consider feelings of guilt and regret.

4. Encourage the abuser to let God change him or her.

5. Teach how to live responsibly, without making excuses, but with accountability to others.

6. Guide in spiritual growth.

7. Show the person how to help others. ${ }^{1}$

On the question of obesity, it is recommended that the chaplain help the counselee to learn principles of sound nutrition and to develop a program of regular exercise to accompany diet. In all matters of counseling, chaplains must refer to a professional counselor. They must also seek advice if the situation is very intense and may result in mental or physical difficulty or if they have no experiential knowledge of the problem.

\section{Marital Problems}

Ellen white wrote:

A well-ordered Christian household is a powerful argument in favor of the reality of the Christian religion--an argument that the infidel cannot gainsay. All can see that there is an influence at work in the family that affects the children, and that the God of Abraham is with them. If the homes of professed Christians had a right religious mold, they would exert a mighty influence for good. They would indeed be the light of the world. ${ }^{2}$

${ }^{1}$ Ibid., 519.

${ }^{2}$ Ellen G. White, The Adventist Home (Washington, DC: Review and Herald Publishing Association, 1988), 36. 
When a Christian home turns into a battleground, the devil is happy. Marital problems exist in many military homes, including those of Seventh-day Adventist military personnel. The military chaplain must be aware of the causes for most marital problems.

1. Tension between the couples. (This usually comes as a result of sexual problems, including a lack of knowledge in how to perform sex, differences in sexual drive, inhibited attitudes about sex, impatience, frigidity, infidelity, and insufficient opportunity for privacy. Other causes may be confusion of roles, inflexibility in religion, diverse values, conflicting needs, personality differences, and money issues.)

2. External pressures such as in-laws who interfere with the couple, husband's and/or wife's vocation and/or career that becomes too demanding, and financial pressure on the family budget that leads to disagreement about spending patterns.

3. Faulty communication and defensive and selfcentered attitudes that create tension and push husband and wife apart.

When counseling a couple with marital problems, it is suggested that the chaplain be alert to the special issues that affect the marriage. Chaplains should be able to teach the couple how to communicate constructively. They must teach problem-solving techniques, help the couple express 
their frustrations and disappointments, keep the husband and wife together, and help the couple to build the marriage on

a biblical foundation.

Gary R. Collins suggests that the counselor ask himself or herself the following questions:

How does the couple communicate?

How do they interact in public and in private?

How do they handle disagreements?

How do they interact when each perceives a problem in a different way?

Do they criticize each other?

Do they attack each other's integrity or use put downs and subtle criticism?

Do they build up one another?

Does one person dominate the other?

Does one or both partners withdraw when they are in disagreement? ${ }^{1}$

Counseling marital problems is one of the most common issues that the Adventist chaplain has to deal with, hence it is recommended that much reading and training be done in this area.

\section{Premarital Counseling}

Forty-five percent of Ghanaians are below the age of fifteen, therefore, the chaplain has to spend some time dealing with the children of military personnel. Hence, a knowledge in premarital counseling is needed. The chaplain can assess the readiness of the youth for marriage, teach biblical principles of marriage, stimulate effective communication skills, provide information on marriage, teach

${ }^{1}$ Collins, 419. 
principle of financial management, help the couple plan for the wedding, and teach the couple the true meaning of love. It is highly recommended that the chaplain not perform a wedding until he or she has counseled the couple.

\section{Physical Illness}

The chaplain, on many occasions, is called to visit with people who are physically ill. The chaplain must study the situation very carefully because, in Ghana, some people may refuse to go to the hospital because of a lack of money or they may think that prayer will heal them. While it is true that prayer can heal, the chaplain, while praying, should help them to seek good medical care, which may include going to the hospital. In Ghana, the chaplain can help the person who is ill to find a hospital that charges less. Sometimes the Seventh-day Adventist Military Church helps to bear the cost of the sickness. Also, among the Adventists there are many medical doctors in Ghana; some are willing to give free care to the sick. The chaplain can recommend patients to such doctors.

Teaching the people the need of a balanced diet and proper sanitation is recommended as a means of preventing some diseases. 
Violence and Abuse

Violence and abuse are very common in the Ghana Armed Forces. This has been true at many military institutions throughout history, and is why John the Baptist warned the soldiers who came to him to "do no violence to no man, neither accuse any falsely, and be content with your wages" (Luke $3: 14$ ).

When it comes to violence, the Ghana Armed Forces has an exceptionally bad record. People see army personnel as a group of people trained to use guns to intimidate people in order to take what does not belong to them. This may be a legitimate conclusion for people who saw the abuse of power by military personnel from 1973 to 1979. These were the years when the armed forces tried to buy things at "control prices."1 Although the Ghana Armed Forces has improved its image, people are afraid of another military regime for it could happen again.

The chaplain is also a part of the military system and therefore knows how the system and those in it work. Being in the system helps the chaplain do ministry in the following ways:

1. They must denounce such violence and counsel those who have violent tendencies. They must be aware that

${ }^{1}$ Control price is the price of item as set by the military regime. It was usually less than the seller had paid for it. 
environmental stress and personal insecurity are the main causes of violence and abuse.

2. They must educate soldiers with an abuse record, about the effect of such abuse and violent behavior and emphasize that such a behavior is not allowed in the Ghana Armed Forces.

3. They must encourage personnel to turn to the Lord to gain self-control. They must warn that the Lord and the military system will take action against those who use force and violence to gain what does not belong to them.

Rape, incest, spouse abuse, and abuse of the elderly are not common in the Ghana Armed Forces, but the chaplain must learn how to counsel individuals with such tendencies.

\section{Choosing Marriage Partners}

About 90 percent of Ghanaians who enter the Ghana Armed Forces are unmarried, but 85 percent of them will marry within two years of joining the armed forces. Hence, the chaplain is often called upon to advise on how to choose marriage partners.

It is said that the most important decision one makes in life is to accept or reject Christ as a personal savior and Lord. Second to this is choosing a marriage partner. Chaplains must bear this in mind as they counsel. This could be one of their most fulfilling tasks.

The chaplain must also bear in mind that the Bible has a lot to say about mate selection (Prov 31; Gen 24). In 
Bible times, choosing a marriage mate was not the responsibility of the couple but of the couple's parents. An example of this is found in Gen 24 where Abraham made a search for a wife for Isaac.

The Bible, however, does lay down one principle: A Christian in choosing a marriage partner should not marry an unbeliever (1 Cor 5:9; 7:39; 7:17; 2 Cor 6:14, 15).

The usual process of mate selection in Ghana is for a male in a bus station, marketplace, or street corner who sees someone who looks good, to approach the woman, talk to her, and, if she agrees to go home, to sleep together for a while and, if she gets pregnant, to marry her. The old cultural way of arranging marriage is gradually disappearing. Now a casual feeling of being in love is the main cause of marriage in Ghana. A casual attraction, "love," should not be the basis for marriage; nor should a "feeling" that love is vanishing be the basis of divorce.

For the military personnel to choose wisely, the chaplain should encourage them to have:

1. Christian conviction--this involves prayer and fasting

2. Complementary needs and backgrounds--this helps marriage partners to have similar goals so they can work together to achieve the same things

3. Emotional and physical attraction for each other-a basis for marriage that makes for harmonious compatibility 
4. Mutual spiritual interests, negotiating ability, maturity, intimacy, and willingness to make commitments

5. Communication ability.

These principles help the military personnel to choose wisely. A good choice does not necessarily lead to a good marriage, but a good foundation for marriage is based on careful selection of a mate who will be a compatible teammate in life.

The spiritual evaluation of a mate must be given consideration above everything else. Gary R. Collins suggests this evaluation.

Is my potential mate a believer? Does his or her life show evidence of the fruits of the spirit (Gal 5:2223)? Have my partner and I ever discussed our spiritual lives, struggles, and goals? Have we ever prayed together? If not, why not? Do we agree on a church, on our basic standard of living, on our views, about right and wrong, and on our perspectives about a Christian home?

\section{Religious Programs}

As already discussed under the chaplain's duties, the chaplain is responsible for providing religious services and programs designed to meet the needs of diverse groups in the Ghana Armed Forces. These include regular appointments-worship services, the Lord's Supper, regular military morning prayers, public prayers, public ceremonies, funeral and memorial service, patriotic programs, and baptism. It

\footnotetext{
${ }^{1}$ Collins, 383 .
} 
means planning special events: marriage, circumcision, holy days, spiritual retreats, and preaching missions. In addition, the Seventh-day Adventist chaplain must conduct Family Seminars, Healthful Living Seminars, Daniel and Revelation Seminars, and Evangelistic crusades in the Ghana Armed Forces. These seminars are dealt with later.

A careful program must be planned for Sabbath/Sunday School lesson studies, promotion of personal evangelism, divine services, and Sabbath afternoon Bible studies. Sundown worship, Wednesday prayer meetings, and choir practice all must be carefully planned by the chaplain and the church leaders.

Chaplains must have a good plan scheduled for all the programs to be conducted. They would do well to follow the Ghanaian way of worshiping and conducting church service by delegating many responsibilities. For example, the sabbath School Council should plan the Sabbath school program in the same way that the personal ministry group draws up their programs. But these group programs must be coordinated by the chaplain to eliminate conflict.

Religious programs must be organized and implemented to ensure spiritual growth and foster soul winning in the church. The day-to-day armed forces programs are expected to be the responsibility of the chaplain. 
Recommended Sequence for Placing seventh-day Adventist Chaplains in the Ghana Armed Forces

In the proposal for this dissertation, I suggested a sequence by which an Adventist chaplain could be appointed in the Ghanaian Armed Forces. Already the Ghana Armed Forces has granted the Seventh-day Adventist Church a place of worship (see chapter 4). The Ghana Armed Forces has gone even further by requesting the Seventh-day Adventist Church to endorse a chaplain for the armed forces to care for the spiritual, physical, mental, and social needs of Adventist military personnel. The remaining recommended sequence for placing a Seventh-day Adventist chaplain in the Ghana Armed Forces is as follows:

1. The church needs to intentionally seek out pastors who have talent, maturity, and are willing to be military chaplains. Such pastors should accept and pass the physical training needed to be accepted as officers in the Ghana Armed Forces. They must also fulfill all the entry prerequisites as listed under the status of the chaplain (see pp. 57-58).

2. The individual must be ordained by the church before applying for the position of a chaplain in the Ghana Armed Forces.

3. The church must endorse and recommend the chosen individual to the Ghana Armed Forces officers Personnel Department, which will forward the application of the church 
appointee to the Ghana Armed Forces Chaplain General Headquarters. The individual will then be appointed and sent to physical training camp and then to Ghana Armed Forces officers School in Teshie Camp, Accra.

Internal Church Procedures and Adjustments to Select Persons for Military Chaplaincy

1. The old image of the Ghana Armed Forces as a brutal, oppressive, and violent force has changed considerably over the years (see p. 43 for information on the old and the new image of the Ghana Armed Forces). The new image can be a basis for appealing to young pastors to consider becoming chaplains in the Ghana Armed Forces. ${ }^{1}$

2. The Conferences and the military establishment should sponsor some of the enlisted personnel to the fouryear college degree in religion and theology at Valley view College with the aim of letting such persons become chaplains in the Ghana Armed Forces. ${ }^{2}$ The Conference sponsorship should include full tuition, accommodations, and living expenses such as food and clothing. The Ghana Armed

${ }^{1}$ As noted in the pages dealing with "Potential for Growth" and "Seventh-day Adventist Attitude Towards Military Chaplaincy." The request of the Burma Camp Seventh-day Adventist Church to the Ghana Armed Forces to provide it with chaplains has been granted. The armed forces is eagerly waiting for the Seventh-day Adventist Church to recommend a chaplain to them.

${ }^{2}$ The Ghana Armed Forces is willing to allow any enlisted young Adventist to study theology in an Adventist school with an emphasis in military chaplaincy to go to such studies without losing seniority. 
Forces agreement is to let such persons go to the school without losing years of service in the army (the years of service would be counted toward retirement).

3. There are a number of Ghanaian theology students attending Newbold College in England, colleges and universities in the Philippines, spicer College in India, West Indies College in Jamaica, Andrews University in the USA, and many other Adventist institutions all over the world. There has been some concern as to the availability of work for all those who are from the Ghanaian field. The Conferences should encourage some to study chaplaincy.

4. A course of study in chaplaincy should be offered at Valley View College in Ghana using the manual in this dissertation as a textbook to create awareness in the young pastors about the importance of becoming chaplains in the Ghana Armed Forces. ${ }^{1}$

5. As already noted, ordination is a requirement for a chaplain to enter the Ghana Armed Forces. An interview with the secretary of the Central Ghana Conference regarding years required for ordination indicates that presently a pastor is required to serve a minimum of four years in fulltime pastoral service. In a discussion of this issue with

${ }^{1}$ I had a face-to-face discussion on this issue with the chairman of the Theology Department of Valley View College, at the James White Library, Andrews University, August 21, 1997, and have been invited to teach this course in the summer after this dissertation is accepted. 
the Conference secretary, he strongly emphasized that the Conference will not reduce the pre-ordination pastoral requirement. However, he noted that since many people are entering the ministry at a younger age, there is the possibility of meeting the age requirement and thereby entering military chaplaincy. ${ }^{1}$

In the present educational system in Ghana (same as the Seventh-day Adventist education system), a pastoral student may complete a Bachelor's degree at the age of twenty-three or twenty-four, which is six years in primary school; six years in junior secondary school; and four years in college. It must be noted that one has to be six years of age before entering elementary school, so a person will be twenty-two or twenty-three after completing college. In this system, one will be able to serve for four years in the ministry and be ordained before the age of thirty-six, the maximum age of entering into the Ghana Armed Forces. It is thus possible for the church to provide chaplains in the Ghana Armed Forces. The conference has four to seven years to ordain a person before such a person becomes ineligible as a chaplain.

6. The Conferences should start a recruiting campaign to get young and dedicated men to take up the work of

${ }^{1}$ Pastor Anthony Yeboah-Amoako, Secretary of the Central Ghana Conference of the Seventh-day Adventist Church, telephone interview by author, October 28, 1997 . 
chaplaincy. This recruiting could be done by the person in the new office suggested in \#7 below.

7. The West African Union and Africa India Ocean Division need to create Adventist Chaplaincy Ministries positions at each level to coordinate with the General Conference Adventist Chaplaincy Ministries office in endorsing the applicants. This chaplaincy department will not only be necessary for military chaplaincy but also to provide chaplains for colleges, universities, police departments, hospitals, and prisons (correctional institutions).

\section{The Ghana Armed Forces Expectations of Seventh-day Adventist Chaplains}

The Ghana Armed Forces expects that the Seventh-day Adventist chaplain will represent fully both the interests of the Ghana defense and of his or her church.

The church must fully support its ordained ministers in the armed forces, and the armed forces expects that the minister, although paid by the government, will be a faithful adherent to the practice and teachings of the church he or she represents. The chaplain will represent all those who share his faith, and also minister to those nondenominational and other military personal who seek spiritual fulfillment from the chaplain.

The chaplain of the Ghana Armed Forces is expected by 
law to conduct appropriate public services for the command to which he or she is assigned.

The Ghana Armed Forces expects that Adventist chaplains will not conduct or participate in any service, rite, or sacrament contrary to the requirements of their denomination. Unless experiences such as combat or a duty mission make services impractical, chaplains are expected to conduct regular Sabbath worship services for their denominational military personnel, their families, and all other personnel who wish to attend. The army expects chaplains to conduct funeral services, the Lord's Supper, baptisms, marriages, counseling, and seminars unless such are contrary to their denominational doctrine.

Chaplains are required to wear clothes that are appropriate for conducting religious services during Sabbath worship. They are also required to wear military uniform during times that they are in office, assigned to duties, or teaching in the officers Military School at Teshie Camp (see p. 62).

In order to provide for the needs of all personnel, the chaplains are required to supply information of the denominational representation of their command by taking a religious census of their organization by obtaining through the Personnel officer the religious preference entered upon each individual qualification and/or service record. The chaplain is expected to do visitation and 
in-service training, and to conduct group Bible studies.

\section{Seventh-day Adventist Expectations of Adventist Chaplains in the Ghana Armed Forces}

The Seventh-day Adventist Church believes that a field of opportunity exists for successful spiritual work by men and women who take it upon themselves to work in the armed forces. Therefore, the Seventh-day Adventist Church expects the following from an Adventist chaplain:

1. Chaplains must always remember that they represent the Seventh-day Adventist denomination and hold Seventh-day Adventist credentials while they work as a chaplain in the Ghana Armed Forces.

2. Chaplains must be faithful to all the beliefs of the Seventh-day Adventist Church while serving in the armed forces.

3. Chaplains are not only to practice the beliefs of the Seventh-day Adventist denomination but are to teach them to others on appropriate ocassions.

4. Chaplains must know that all tithes and offerings collected in the Seventh-day Adventist churches in the armed forces go to the Conference or Mission in which the barracks is located.

5. Chaplains must carry on all the duties that the armed forces require of them which are not contrary to the doctrines of the Seventh-day Adventist Church.

6. Since the chaplain is an ordained seventh-day 
Adventist minister, he or she is required to perform all the duties expected of a pastor in a civilian setting. These duties include preaching, evangelism, baptism, counseling, visitations, officiating at weddings, funerals, infant dedications, communion services, attendance at local Conference pastors' meetings, and all other things the civilian pastor does. The chaplain must remember that on the issue of baptism, he or she cannot baptize any military person who does not desire to be a Seventh-day Adventist. For presently in Ghana, all Seventh-day Adventist ministers including chaplains cannot baptize any person who does not desire to be a seventh-day Adventist. In some of the world, however, Seventh-day Adventist chaplains, in real ocassions baptize people who wish to be Christians but not necessary Seventh-day Adventist Christians. ${ }^{1}$

7. Chaplains are expected to be obedient to the charge of God through Paul to Timothy: "Preach the word, be instant in season, out of season, reprove, rebuke, exhort with all long-suffering and doctrine" (2 $\operatorname{Tim} 4: 1,2)$.

Chaplains must remember that they represent christ in a military officer's uniform, hence, they must be aware of the urgency of Christ's work. To win souls to Christ's kingdom must be the first consideration.

${ }^{1}$ It must be understood that the purpose of baptism is not only to become a member of a church but also to become a Christian. Baptism and church membership are two distinct and different actions. 
8. Chaplains are expected to have a strong devotional family life together with personal Bible study and prayer.

The most important concern to the minister must be a personal relationship with Jesus Christ. This can be meaningful only as long as there is a consistent devotional life. Unless time is set aside for daily study of the Bible and prayer to sustain the soul, the minister's work will be powerless. ${ }^{1}$

Chaplains must be aware that the many duties expected of them both from the church and the Ghana Armed Forces can make them neglect this devotional priority, but this must not happen. The chaplain must spend time alone with God. E. G. White wrote this concerning meditation:

It would be well for us to spend a thoughtful hour each day in contemplation of the life of Christ. We should take it point by point, and let the imagination grasp each scene, especially the closing ones. As we thus dwell upon His great sacrifice for us our confidence in Him will be more consistent, our love will be quickened, and we shall be more deeply imbued with His spirit. ${ }^{2}$

9. The Seventh-day Adventist Church expects its chaplains in the armed forces to have a twofold responsibility: to make disciples and to teach them and to bring others to Christ and build them up in Christ. The chaplain is both an evangelist and a shepherd of the flock, seeking to win and to teach, declaring to all the counsel of

${ }^{1}$ Ministerial Association of Seventh-day Adventists, Manual for Ministers (Washington, DC: General Conference of Seventh-day Adventists, 1977), 9.

${ }^{2}$ Ellen G. White, The Desire of Ages (Washington, DC: Review and Herald Pub. Assn., 1974), 83. 
God, and building up the believers in the Word and doctrines of God. ${ }^{1}$

10. Chaplains should refuse to engage in or promote any business enterprises even though these may in themselves be worthy, and they should refrain from participating in and promoting any speculative enterprises. It is also recommended that military chaplains should have no engrossing interests that would keep them from the great work of bringing souls to the Savior.

11. Since the church expects its ministers to dress carefully, neatly, and appropriately, military chaplains must wear uniforms and clothes befitting the dignity of their position. The clothing must be tidy.

The influence of the minister who is careless in his dress is displeasing to God, and the impression made upon his hearers is that he looks upon the work in which he is engaged as no more sacred than common labor. And not only this, but instead of showing them the importance of propriety and taste in clothing, he sets them an example of slackness and untidiness, which some are not slow to follow.

God expects $\mathrm{His}$ ministers, in their manners and in their dress, to give a fitting representation of the principles of truth and the sacredness of their office. They are to set an example that will help men and women to reach a high standard. ${ }^{2}$

The Ghana Armed Forces expects its officers to set an example of neatness in dressing for the lower ranks; hence, the Adventist chaplain must abide by the armed forces and

'Minister's Manual (1977), 11.

${ }^{2}$ Ellen G. White, Gospel Workers (Washington, DC: Review and Herald Assn., 1915), 174. 
the Adventist Church requirements.

12. Seventh-day Adventist chaplains in the Ghana Armed Forces are expected to be faithful tithepayers. They should not seek personal gifts from non-church members or church members. They are not to discuss their financial affairs with church members. They must, if needed, discuss their financial affairs with the employing body.

13. Chaplains must make efforts to self-improve through correspondence courses, reading of newspapers, magazines, and any publication that will draw them closer to God and the knowledge of the signs of the times.

14. Chaplains must serve God in moral purity and holy living (Rom 13:16; 1 Cor 5-16; 2 Cor 7-13; Gal 5, 6; 1 Pet $2-5$; 1 John; 3 John).

15. Chaplains are expected not only to win souls to Christ but to establish new converts in the faith. New members must be taught in such a way that their faith is firmly established and integrated into the active program of the church.

16. The Seventh-day Adventist Church expects excellence from its chaplains so that the name of God will be blessed by all with whom they come in contact.

Suggestions for Ghana Armed Forces Evangelism Including Healthful Living Seminars and Marriage Seminars

When Seventh-day Adventist military chaplains apply, in a tactful way, the excellent training received through 
Adventist education, the church's well-defined, powerful biblical base of doctrine, and the inspired and appealing writings of Ellen White, the Ghana Armed Forces barracks across the country will be an open field of evangelism. Being tactful is a very essential requirement for successful, long-lasting evangelism in the Ghana Armed Forces, because while the Ghana Armed Forces allows chaplains from all denominations the religious freedom not only to practice their religion but to win converts into their religion, untactful evangelism could result in competition that could cause division among the chaplains in the Force. E. G. White wrote this about the need of being tactful:

In the work of soul-winning, great tact and wisdom are needed. The Savior never suppressed the truth, but He uttered it always in love. In His intercourse with others, He exercised the greatest tact, and He was always kind and thoughtful. He was never rude, never needlessly spoke a severe word, never gave unnecessary pain to a sensitive soul. He did not censure human weakness. He fearlessly denounced hypocrisy, unbelief, and iniquity, but tears were in $\mathrm{His}$ voice as He uttered His scathing rebukes. He never made truth cruel, but ever manifested a deep tenderness for humanity. Every soul was precious in His sight. He bore Himself with divine dignity; yet He bowed with the tenderest compassion and regard to every member of the family of God. He saw in all, souls whom it was His mission to save. ${ }^{1}$

since success in business requires tactfulness, such qualities are needed by chaplains to be successful in God's work.

${ }^{1}$ Ibid., 117; see also idem, Testimonies for the church, 9 vols. (Washington, DC: Review and Herald Pub. Assn., 1974), 5:276. 
For chaplains to be very successful in evangelizing the Ghana Forces military personnel, they must be well-informed not only in the Bible but in day-to-day information about the events and concerns of the Ghana Armed Forces military personnel. Gentleness, humility, earnestness, determination, courage, patience, simplicity, dignity, zeal, and love are also needed for those Adventists in the Ghana Armed Forces.

The Adventist chaplain can evangelize through health seminars, evangelistic outreach seminars, and marriage seminars.

\section{Health Seminars}

The health message is a door through which the truth will find entrance to many homes in the Ghana Armed Forces. White wrote:

Let the teachings of health reform be brought into every effort made to get the light of truth before the people. Let workers be selected which are qualified to teach the truth wisely in clear, simple lines. ${ }^{1}$

Health seminars can be organized by the chaplain with the help of the Adventist Church in the barracks. The chaplain may not be the person best qualified to conduct. these seminars, but he or she must be the one in charge of the program. All the pre-effort preparation and organization of a church for an evangelistic campaign must

${ }^{1}$ Ellen G. White, Evangelism (Washington, DC: Review and Herald Pub. Assn., 1974), 533. 
be followed prior to conducting a health seminar (see pp. 103-106).

The seminars will be conducted in a time frame of five days a week for four weeks. A team of medical doctors, nurses, nutritionists, health educators, and health officers should be invited to conduct health seminars. The following topics are suggested for the four weeks of seminars.

Week one

1. Knowing more about your own body

2. Eight prescriptions for good health

3. Ten reasons why you don't need alcohol

4. The effects of smoking

Week Two

1. Abstinence or protection--what you need to know about AIDS

2. How to manage your blood pressure

3. How to postpone a heart attack

4. Cancer and you (how to minimize the risk of having cancer)

5. Living a drug-free life

Week Three

1. The importance of a balanced diet

2. How to prepare a balance diet

3. Family planning

4. Diabetes

5. Answers to your health questions 


\section{Week Four}

1. Germs and people (movie presentation)

2. Free health screening

3. Childhood nutrition

4. Pregnancy checkups (how to care for the unborn)

5. God wishes us good health and prosperity (the Bible and health)

Ghanaians as a whole have begun taking their health more seriously. The average length of life of a Ghanaian male is 53.6 years, an increase of 2.6 years in the last ten years. For females, it is 56.8 years, an increase of 3.4 . years.

Alcohol and smoking-related diseases, together with car accidents, are the leading causes of death among Ghanian men. These are followed closely by diabetes and sex-related diseases such as AIDS. Malaria and malnutrition kill many young people and children.

It is recommended that chaplains learn more about exercise, nutrition, diets high in saturated fat and cholesterol, obesity, high blood pressure, sleep, stress, and the effects of alcohol, diabetes, and malaria. This will help them to answer many of the questions commonly asked by people in the Ghana Armed Forces.

Alcohol-related problems such as traffic deaths, teenage accidents, broken homes, and deformed children must 
be made known to the military personnel and their family during these seminars.

\section{Marriage Seminars}

Marriage used to be for life in the Ghanaian understanding, but now termination of the relationship is as common as the formation of the relationships in Ghana and in the armed forces.

Marriage seminars, therefore, are one way to attract interest in the Bible and give people a message of hope.

The chaplain should plan the seminar to last for two weeks. Since a marriage seminar usually attracts people who are seriously in need of help, the meetings should not be of a quick sermonette type of presentation. They should be interactive presentations that allow the people attending to be involved. Two to two-and-one-half hours of serious involvement in the participants' marital issues should be conducted at every session.

From the beginning of the seminar to the end, the chaplain must establish as his or her basic premise that the Lord God created marriage; that His purpose for marriage is a relationship based on joy, kindness, and commitment; and that marriage is a blessed institution. Sin has distorted marriage, but when the creator of the marriage institution is allowed to direct it, it will succeed.

The seminar topics for two weeks are suggested as follows: 
Week One:

1. The owner, origin, and purpose of marriage (All people present should be allowed to write what they think are the causes of problems in marriage. These lists will be collected by the deacons before the presentation. This will allow the chaplain to address and discuss the problems listed during the seminar.)

2. The roles of husband, wife, children, in-laws, and friends in marriage

3. Forming a marriage relationship (dating, engagements, premarital sex)

4. Expectations and realities of marriage

5. Communication in marriage (importance of communication, definition of communication, importance of listening, barriers to communication, conflict in marriage communication, and managing conflict in marriage through communication)

6. Intimacy in marriage (sexual intimacy in marriage, barriers to intimacy such as cultural and sub-cultural, psychological barriers hindering sexual intimacy, family devotions, and satisfactory intimacy)

7. Christian parenthood (parental responsibilities, biblical model of parenthood, values, roles, and discipline)

Week Two:

1. Family finances (who is the boss, financial planning, family budget, money and conflict in marriage, a 
will, credit, dual-income couples)

2. Keeping anger from wrecking the marriage (good and bad anger, how anger can trouble a marriage, when spouses do not act like partners, when winning the fight is more important that upholding the marital covenant, creative ways of using anger, skills for handling angry feelings, anger as a positive tool)

3. Love, submission, and equality in marriage

4. Married couples' soul searching; needs of the unmarried (On this day, all the married men attending will go to one room to discuss what they can and will do to make their marriages successful and happier. All the married women will go to another room to discuss how to make their marriages happier and more successful. The men and women in their own sections will discuss what they think are the problems their men or women do not understand. The unmarried people will go to other rooms--men and women separate--to discuss what is preventing them from making a choice. After forty-five minutes, all groups will come together to share their findings and proposed solutions. The chaplain will close with a twenty-minute presentation in summary outline of the positive ways to solve marriage problems.)

5. Christ the center of marriage (the importance of making Christ the center of marriage) 
6. Renewing marriage commitments and how to find a successful partner

7. Culture and the Christian family, marriage and heaven, principles of marriage and singleness.

During the two-week marriage seminar, the chaplain's wife/husband can play a great role by being present at every meeting and being available to participate in the counseling sessions.

If the chaplain is properly prepared with prayer and training for these marriage seminars, they will be a good means of reaching the unreached, attracting both higher and lower ranks, and presenting to Christians and Muslims the Seventh-day Adventist message. The chaplain should have a follow-up plan for those who accept the Adventist message.

\section{Evangelistic outreach}

For chaplains to be effective in an evangelistic campaign they must counsel with and inspire the cooperation of the Seventh-day Adventist military personnel, church elders, and all the members of the church in the barracks where they minister. Concerning the need of lay involvement in evangelism, White wrote:

The work of God in this earth can never be finished until the men and women comprising our church membership rally to the work, and unite their efforts with those of ministers and church officers. . . The minister should not feel that it is his duty to do all the talking and all the laboring and all the praying; he should educate helpers in every church. Let different ones take turns in leading the meetings, and in giving Bible readings; in so doing they will be 
calling into use the talents which God has given them, and at the same time be receiving a training as workers. ${ }^{1}$

The preparation and training of the church members for cooperation during the evangelistic campaign must not be lost sight of.

Some suggestions for preparing the church for evangelistic efforts in the Ghana Armed Forces barracks are:

1. Let the church know the importance of the evangelistic meetings. This preparation program must be at least sixteen weeks before the commencement of the meeting.

2. The chaplain should contact each member of the church and help them discover their gifts and how to best use their gift.

3. The church should spend the week prior to the evangelistic meeting in prayer and revival. This week could also be called a revival week.

4. All evangelistic plans, programs, and materials should be given to the church members long before the meeting; this will help them to know how serious the meeting is going to be.

5. House-to-house visitation must be done by church members at least twice a week. Involve as many as possible in giving Bible studies.

6. Encourage team work and assure the church members

'White, Gospel Workers, 352, 197. 
that they are all laboring together with God.

7. Organize evangelistic committees. Select leaders

The chaplain will need the following committees to function in order to conduct an evangelistic campaign in the Ghana Armed Forces.

1. Prayer Band Committees. They will be responsible for selecting people who will set aside certain times to pray for the meeting. They will meet at certain times for special seasons of prayers.

2. Music Committee. Since Adventists are noted in Ghana for their excellent talent in music, this committee will secure the best musical talents and arrange for them to 4 sing at least twenty minutes before the preacher starts preaching.

3. Advertising committee. It will be responsible for handbill posters, radio and TV announcements, and the selection of literature that will be distributed during the evangelistic meetings.

4. Visitation Team or Bible Workers Committee. They will be responsible for selecting lay Bible workers who will do personal ministry work during the meeting. The chaplain must have training classes for them.

5. Health Ministry Committee. Since ten-minute health lectures will be presented each meeting during the evangelistic campaign, this committee will select medical 
doctors and nurses who can give these lectures.

6. Budget committee. It will be responsible for raising funds and appropriating the money for the evangelistic campaign.

7. Ushers and deacons need to be selected for the meetings.

An evangelistic campaign in the Ghana Armed Forces is recommended not to exceed three weeks because that seems to be what is most convenient for the hearers and what has worked in the past.

The following topics are suggested:

\section{Week one}

1. Our chaotic world emphasizes creation, sin, and sinfulness

2. He broke what he borrowed: Birth, death, and resurrection of Christ

3. Behold, Christ Jesus cometh the second time

4. Prayer meeting

5. Heaven, the city in space

6. The ceremonial and moral law of God

7. Love, courtship, marriage, and family

Week Two

1. The golden image

2. Guardian angels

3. Where are the dead?

4. Spiritualism 
5. Is God particular?

6. Adam's mother's birthday celebration. Who is Adam's mother? When is her birthday?

7. The sin that God cannot forgive

\section{Week Three}

1. Who changed the sabbath?

2. Bible baptism: sprinkling, pouring, or immersion?

3. Why so many churches?

4. Speaking in tongues

5. How to multiply your money

6. How to postpone your own funeral

7. Thousand years of what?

The following is a suggestion of the nightly schedule of the evangelistic campaign.

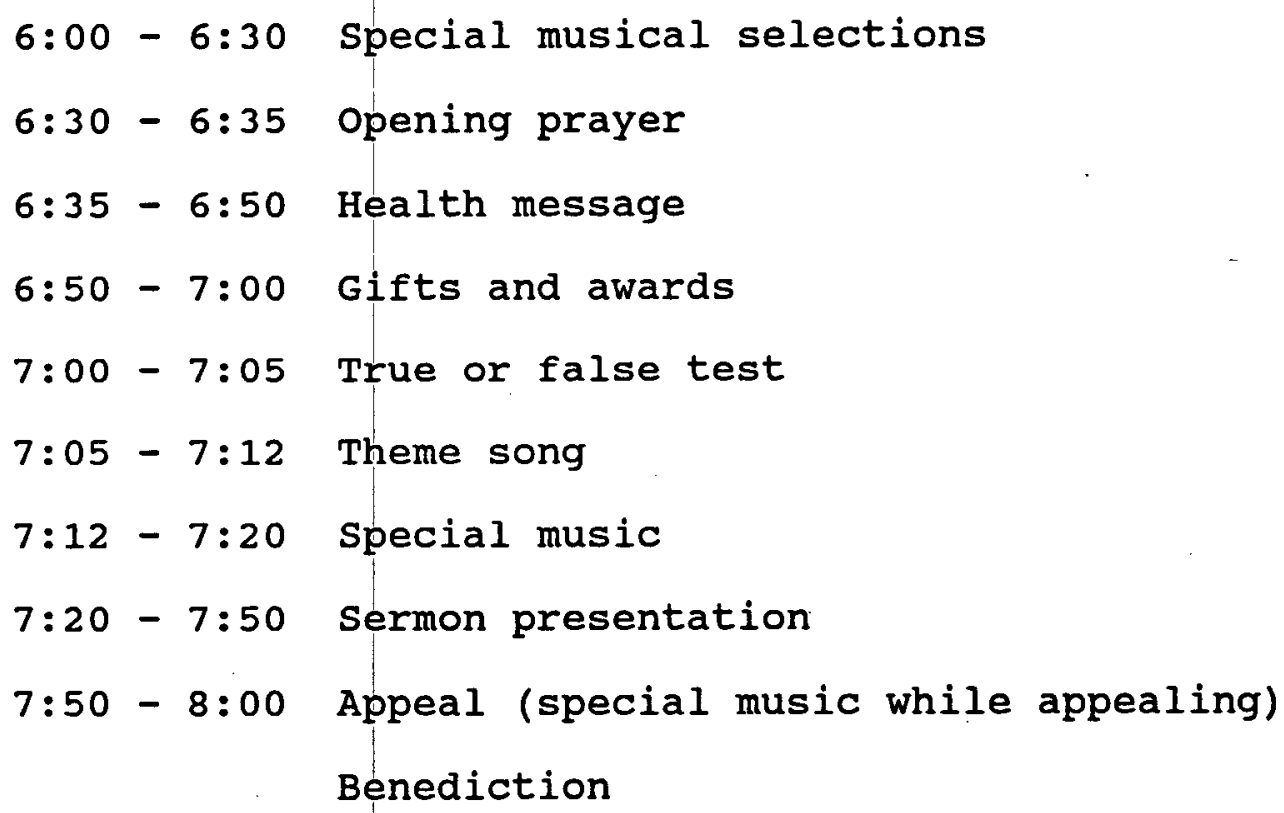

During the evangelistic campaign, the Sabbath service presentation must be a biblical story that emphasizes a 
particular doctrinal truth in the Bible; e.g., Naaman the leper. This sermon could be used to emphasize the importance of following God's direction and doing what He says without trusting and forming one's own opinions.

It is recommended that the chaplain make decision cards for people who accept Christ, people who accept the Sabbath, people who accept the law, and people who decide to become Seventh-day Adventist and want to be baptized.

Voice of Prophecy Bible study lessons should also be given during the crusade. Those who successfully complete the course should be honored during the last Sabbath service.

The military chaplain, in preparing for a successful evangelistic campaign in the Ghana Armed Forces, should remember to include church members by encouraging them to have a contact list and prayer list. The church members must be trained as Bible workers who will lead in visitation. Child care facilities are needed to take care of the children of those attending the meetings. The church must also be prepared to receive new members. Radio and newspaper announcements are also needed.

The ultimate key to evangelistic success, however, depends upon how well the chaplain and the church identify themselves with Christ's method of preaching--mingling with the people as one who desires their good, showing sympathy to the neglected and forgotten, ministering to the needs of 
the people, winning their confidence, and bidding them to follow Him.

Jesus saw in every soul one to whom must be given the call to His kingdom. He reached the hearts of the people by going among them as one who desired their good. He sought them in the public streets, in private houses, on the boats, in the synagogue, by the shores of the lake, and at the marriage feast. He met them at their daily vocations, and manifested an interest in their secular affairs. He carried His instructions into the household, bringing families in their own homes under the influence of $\mathrm{His}$ divine presence. His strong personal sympathy helped win hearts. ${ }^{1}$

The chaplain should find a point of contact in the Ghana Armed Forces by acquainting himself with the military personnel and their families. If possible, before the evangelistic meetings the chaplain should personally visit people in their homes. The chaplain should also exercise patience with people, give the military personnel time to talk back, present the message of God and His doctrines in love and great clarity, speak enthusiastically, and avoid long sermons. This will help people decide for christ. The chaplain must lift Christ up, because if Christ is lifted up He will draw all men to Himself. The chaplain should remember that he who wins a soul for christ is a wise person (Prov 11:30).

There is a need of coming close to the people by personal effort. If less time were given to sermonizing, and more time were spent in personal ministry, greater results would be seen. The poor are to be relieved, the sick cared for, the sorrowing and the bereaved comforted, the ignorant instructed, the

${ }^{1}$ White, Desire of Ages, 139. 
inexperienced counseled. We are to weep with those that weep and rejoice with those that rejoice. Accompanied by the power of persuasion, the power of prayer, the power of the love of God, this work will not, can not, be without fruit. ${ }^{1}$

\section{Sabbath Issues}

Since almost all Seventh-day Adventists in the Ghana Armed Forces became Adventists after joining the armed forces, most of them are in a position which requires them to work on the Sabbath. The chaplain has to deal with many military men and women whose duty falls on Sabbath and who want to observe the Sabbath in its true spirit.

About 25 to 30 percent of the Seventh-day Adventists in the force are assigned Sabbath duties. The Air Force is an example of this. Air Force personnel might come to the chaplain asking him to plead with the commanding officer to to allow a trade in schedules for duty on sundays instead of Sabbath. The chaplain might do well by asking the seventhday Adventist personnel to first try to trade with someone who wants to work on Sabbath instead of Sunday. Many nonAdventists want sundays off to watch soccer, so there is a possibility that a trade will work out.

The Seventh-day Adventist military person should first talk to the scheduler and if unsuccessful then go to the commander, coordinating each step with the chaplain for

${ }^{1}$ Ellen G. White, Ministry of Healing (Boise, ID: Pacific Press Pub. Assn., 1950), 143-144. 
guidance and support. The chaplain should very rarely, if ever, approach anyone ahead of the Seventh-day Adventist personnel.

During a time of war or national emergency, Adventist military personnel must make decisions concerning the Sabbath and their military duties based on their convictions as to what is right and appropriate. Decisions about sabbath work are based on several additional issues such as (1) Is it a kind of work which one must perform everyday for personal hygiene and tidiness of one's personal life? (2) Is the work directly essential to preservation or saving of life or the comfort and care of the sick and the wounded? These convictions must be firmly expressed in a respectful manner. Many Sabbath problems may be avoided through the steps mentioned above.

\section{Noncombatancy in the Ghanaian Military}

As a nation, Ghana has not engaged in war since 1957 when it gained its independence. The Ghana Armed Forces served under the British during the second world war (19391945) and the Congo war (1954-1956). They served as part of the United Nations peacekeeping force which came under fire in the Middle East, Liberia, Rwanda, Sierra Leone, and Bosnia. A number of Adventist military personnel lost their lives in Liberia when their armored car came under attack and they refused to return fire. The reason they refused to return fire is unknown. No one has ever thought to ask for 
noncombatancy status. Hence, no consideration has been given to the issue of noncombatancy.

The bearing of arms is a requirement in the Ghana Armed Forces. Refusal to fire a weapon in combat is against the law and the punishment can include serving up to twelve years in jail. Chaplains and those in the medical field are exempted from the bearing of arms. The person who upon being hired to the armed forces refuses to be trained with weapons will be terminated on the very first day of training. No further penalty will be given since he or she will be considered as not being a member of the armed forces.

Since more than 90 percent of the Adventist military personnel in the Ghana Armed Forces became Seventh-day Adventists while in the armed forces, bearing arms was not an issue for them. Since the bearing of arms has not been an issue for the church in Ghana, Adventists who joined the military never raised the subject. Most Adventist military personnel have been trained as combat soldiers and usually received assignments where they might be expected to use their weapons. ${ }^{1}$ While this has not been an issue for the

'Some Seventh-day Adventists are assigned as guards of the commanders, armed storage facilities, and two of them are assigned presently as the personal bodyguard of the President. This position requires bearing arms and using it in cases of coup attempts or assassination attempts on the president or the commanders. Coup attempts are common in Ghana. 
military or the church in Ghana, it is addressed here because the Seventh-day Adventist denomination has a recommendations regarding the bearing of arms. Therefore, it is possible that an Adventist chaplain may have to address this issue in the future. This issue is now addressed in the following sequence.

1. The historic Seventh-day Adventist position on the bearing of arms

2. The bearing of arms in the old Testament

3. The bearing of arms in the New Testament

4. The Ghanaian Seventh-day Adventist chaplain and the issue of bearing arms

a. Seventh-day Adventists in the Ghana Armed Forces and the bearing of arms

b. Advice that a chaplain would give to a Seventh-day Adventist who wants to join the Ghana Armed Forces.

\section{Issues of Noncombatancy}

The Historical Seventh-day Adventist position on the Bearing of Arms

Study of the Israelite theocracy in the OT and the spiritual kingdom of Christ in the NT has led the Seventhday Adventist Church to recommend a modified conscientious objection position, namely noncombatant. Therefore, the church has taught that its members who are called to military service should ask for noncombatant status. The 
recommendation presented in an action of the 1954 Annual

Council of the General Conference Committee reads:

Genuine Christianity manifests itself in good citizenship and loyalty to civil government. The breaking out of war among men in no way alters the Christian's supreme allegiance and responsibility to God or modifies his obligation to practice his beliefs and put God first. The partnership with God through Jesus Christ, who came into this world not to destroy men's lives but to save them, causes Seventh-day Adventists to advocate a non-combatant position, following their divine Master in not taking human life, but rendering all possible service to save it. In their accepting the obligations of citizenship, as well as its benefits, their loyalty to government requires them to serve the state in any non-combatant capacity, civil or military, in war or peace, in uniform or out of it, which will contribute to saving life, asking only that they may serve in those capacities which do not violate their conscientious convictions. 1

It is important to note that this is a teaching and not a test of fellowship. Individual members are free to make their own decisions. ${ }^{2}$ It is recommended as a position most consistent with the example of Christ, but members are

${ }^{1}$ National Service Organization of the General Conference of Seventh-day Adventists, "Seventh-day Adventist Teachings on Governmental Relations and Non-Combatancy," Washington, DC; $1982,4,5$.

${ }^{2}$ For more information on war and noncombatancy see Beth Ellen Boyle, Words of Conscience, 10th ed. (Washington, DC: National Inter-Religious Service Board for Conscientious objectors, June 1983); John Helgeland, Christians and the Military: The Early Experience (Philadelphia: Fortress Press, 1985); John Kinchy, Those Who Say No: A Chaplain's Guide to counseling conscientious objectors (Philadelphia: Central Committee for Conscientious objectors, 1976); Marlin E. Thomas, Yahweh war in Early Israel: An Inquiry into the Significance of God's Role in the Early Wars of Israel (Deerfield, IL: Mennonite Brethren Biblical Seminary, 1966); Barry Black, The Seventh-day Adventist Military Chaplain: A study of Beliefs and Functions in Tension With Military Life (Ann Arbor: University Microfilms, 1982), 77-119. 
free to choose according to their own conscience.

\section{Bearing Arms in the old Testament}

As noted in chapter 2, use of weapons in war was part of the Israelites' practice in the OT. With the exception of the book of Ruth, all other OT books contain references to combat or language of combat. ${ }^{1}$ In OT history, the people of God are in frequent combat with other nations at God's command. "Yahweh" is often described in the OT as a combatant God. Some examples are: "The Lord is a man of war (Exod 15:6); "Yahweh, the mighty man of battle" (Isa $42: 3$ ); "The warrior of victory" (Zeph 3:17); "The Lord, strong and mighty, the Lord mighty in battle" (Ps 24:8) $\boldsymbol{i}^{2}$ and "The Lord who teacheth my hands to war" (Ps 18:29, 32) .

God is also seen in the OT as actively participating in war. An example of this is in the book of Joshua when as Joshua began the conquest of Canaan the Lord appeared to the new leader of His people to assure him of victory and success.

And it came to pass, when Joshua was by Jericho, that he lifted up his eyes and looked, and, behold, there stood a man over against him with his sword drawn in his hand: and Joshua went unto him, and said unto him, Art thou for us, or for our adversaries? And he said, Nay; but as captain of the host of the Lord am I now come. And Joshua fell on his face to the earth, and did worship, and said unto him, what saith my Lord unto his servant? And the captain of the Lord's host said

${ }^{1}$ Thompson, 11.

${ }^{2}$ Ibid. , 12 . 
unto Joshua, loose thy shoe from off thy foot; for the place whereon thou standest is holy. And Joshua did so. (Josh 5:13-15)

The angel in the above verses declared himself as the "Captain of the Lord's host" (host, meaning the armies of heaven) (Josh $6: 2,20-21) .1$ Joshua received assurance that he would not stand alone as the head of the Hebrew army. As Captain, the Lord Himself would be there, superintending, disposing, ordering, and commanding. The Sar (captain) of the Lord's Host then ordered Joshua to "loose thy shoe from off thy feet, for the place whereon thou standest is holy." Joshua complied and fell on his face to the earth and worshipped. This is further proof that the sar of the Lord's host was somebody far higher than an angel; for angels do not expect humans to pay them homage or do them obeisance, let alone worship them (Rev 22:8-9).2

In Josh $6: 2$ he is designated by the divine name, the LORD (Exod $6: 3 ; 15: 2$ ). It should be noted that Josh 6 is a continuation of the narrative of 5:13-15. Commenting on this passage, Ellen White wrote:

Withdrawing from the encampment to meditate and to pray that the God of Israel would go before His people, he

${ }^{1} E$ lsewhere the word translated "host" refers specifically to armies (Judg $4: 2,7$ ) often to the armies of Israel (2 Sam 2:8), sometimes to angels, as here ( $1 \mathrm{Kgs}$ $22: 19)$, and frequently to the stars of heaven. Gen 15:1821; Judg 6:34; 3:10; 4:6, 23; Exod 17; Num 31; Exod 17:17; Pss 144:1; 140:7; Exod 14; 27; 1 Sam 7:10; Dan 7:20; Josh $6: 20 ; 6: 17-21 ; 24: 12$; Exod 23:28; Gen 14.

${ }^{2} \operatorname{Rev} 19: 10$. 
beheld an armed warrior, of lofty stature and commanding presence, "with his sword drawn in his hands." To Joshua's challenge, "Art thou for us, or for our adversaries?" The answer was given, "as captain of the host of the lord am I now come," the same command given to Moses in Horeb "loose thy shoe from thy foot; for the place whereon thou standest is holy" revealed the true character of the mysterious stranger. It was Christ, the Exalted one, who stood before the leader of Israel. ${ }^{1}$

The heavenly being who appeared to Joshua in Jericho is called, in Josh 5:15, "the Captain [Sar in Hebrew] of the Lord's Host." In the book of Daniel, the Hebrew word Sar appears no less than seventeen times and refers to princes. The word refers to the Prince of princes (Dan 8:25), Michael, one of the chief Princes (Dan 10:13). Michael, the great Prince (Dan 12:1), is also referred to in Isa 9:6 as Sar-Sharlom, Prince of Peace. The Captain of the Lord's Host also led the Lord's host to the heavenly war (Rev 12:79). ${ }^{2}$

"Yahweh" is sometimes given combatant names in the OT (see p. 125). He ordered Israel to go to war and often fought on its behalf. This was because the government of Israel was exceptional in human history. God governed His

${ }^{2}$ Ellen G. White, Patriarchs and Prophets Mountain View, CA: Pacific Press Pub. Assn., 1958), 487-488.

2"Sar-Shalom," Theological Wordbook of the old Testament (Chicago: Moody Press, 1980), 884. See also Ellen G. White, The Great controversy (Omaha, NE: Pacific Press Pub. Assn., 1950), 633, 641, 642, 657; "Daniel," SDA Bible Commentary, ed. F. D. Nichol (Washington, DC: Review and Herald Publishing Association, 1953-57), 4:859-861. 
people directly. He was their ruler and law-giver. ${ }^{1}$ This theocratic government was not to be like other nations--"You will be for me, a kingdom of priests, and a Holy nation" (Exod 19:6). This is re-emphasized in Exod 33:16 and Num 23:9. God was to be the central authority. ${ }^{2}$ For God's purpose to be accomplished, He had to lead Israel with mighty hands, performing wonders, signs, miracles, and to save His people from destruction from their enemies. This involved God driving the heathen nations out of the promised land and also fighting on the side of His people against the enemies of destruction (Josh 1:1-9). God was not always, however, on the side of Israel, for when they departed from Him, He refused to be on their side and they were smitten (Num 14:42-45). This theocracy (direct rule of God) no longer exists. Hence, God does not directly administrate the government of any nation as He did in the days of Israel.

Generally, killing in war by Israel is commanded and directed by God. Thus, the use of weapons and killing by Israel of its enemies appears to be morally justified in the OT (Num 31:1-19).

Now let us look at the key words used for killing in

\footnotetext{
'National Service Organization of the General Conference of Seventh-day Adventists, "Why Seventh-day Adventists Are Non-Combatants" (Washington, DC: General Conference of Seventh-day Adventists, 1917), 3 .

${ }^{3}$ White, Patriarchs and Prophets, 376, 603.
} 
the OT. How these words are used follows:

1. Muth: the most common word used in the Bible concerning death. It is used 825 times and is the root in death or to die; hence, it is mostly translated "die," "slay," or "be put to death and it is used to denote warfare."

2. Nakeh: used 500 times. "It is rooted in to hit"; hence, it is translated 340 times as "smite," 90 times as "slay."1 Its usage is usually associated with war.

3. Harag: used 170 times; 132 times it is translated as "slay" and mostly used concerning killing in warfare.

4. Ratsach: "Thou shalt not kill" (thou shalt do no murder), Exod 20:13. Ratsach is never used in the context of war. In the OT, willful killing is condemned by God, and the individual committing such an act could be punished by death. ${ }^{2}$ This commandment is the backbone of pacifism (the belief that all wars are evil; hence, Christians are to have nothing whatsoever to do with wars). Ratsach, used in Exod $20: 13$, is used in the Hebrew Bible seventy times. For forty-seven times it is translated as "slayer"; e.g., Num

${ }^{1}$ C. Mervyn Maxwell, "Non-combatancy or Pacifism," TMs, E. G. White Research Center, Andrews University, Berrien Springs, MI, 2 .

${ }^{2}$ Ibid. See also Gen $34: 25 ; 2$ Sam $2: 23 ; 3: 27-30 ; 20: 3-$ 23; Deut 22:26; Judg 20:14; Deut 6:17; Exod 20:13. "Yahweh" in the OT also selected people for war (Num 1, 2, 3, 45, 46; $26: 2 ; 1: 3-7)$. Israel was God's battle axe and weapon of war (Jer 5:20-24; Ezek 6:1-7; 21:1-5; 21:8-12, 14，15，25-32). He helped His people smite their enemies (Judg 6:1-16). 
$35: 11,25,26,27,28$; Deut $4: 42 ; 19: 3,4,6$; Josh $20: 3,5$, $6 ; 21: 13,21,27,32,38$.

It is also translated as "murder" or "murdered" twentythree times; e.g., Jer 7:9; Num 35:19, 21, 30, 31; Job $24: 14 ; 2 \mathrm{Kgs} 6: 32$; Isa $1: 21 .^{1}$ It is translated "kill" six times. Example: Exod 20:13; Num 35:27; Deut 4:42; 5:17;

1 Kgs $21: 19$; Hos 4:2. God did not use the most common words for killing in the sixth commandment such as mutch, Nakeh, or Haraq, but used Ratsach. Killing in war can be distinguished from murder. ${ }^{2}$

Ratsach (murder) is often used in the context of the city of refuge. If anyone commits ratsach, he or she should be put to death. In order for the alleged murderer not to be a victim of a vengeance slaying, the cities of refuge were established for escape until he or she was given a fair trial (Num 3:7; Deut 19:1-13). In order to have time to investigate, the responsible person must run to the city of refuge.

It is evident from the study of all the forty-seven usages of ratsach in the OT that it is never used for warfare but rather slaying of one individual by another

1 "Exodus," SDA Bible commentary, ed. F. D. Nichol (Washington, DC: Review and Herald Publishing Association, 1953-57), 1:606.

${ }^{2}$ Maxwell, 2, 3 . 
individual and the development of a bloodfeud arising therefrom.

"Thou shall not kill," therefore, is restricted to murder or the suspicion of murder; the killing of one individual by another individual as a result of private dispute or hatred. Ratsach refers to premeditated killing. ${ }^{1}$ Killing in war is not addressed as $\sin$ in the OT, but murder was a sin punishable by death.

Weapons of war used in the OT are as follows:

sword (1 Sam 13:9) $i^{2}$ (2) knives (Gen $\left.22: 6,10\right) i^{3}$ (3) spears (Josh $8: 18,26) i^{4}$ (4) shield (Judg $\left.5: 8\right) i^{5}$ (5) armor (1 Sam $14: 16 ; 17: 38) ;(6)$ arrows (1 Sam $20: 36,37$; 2 Kgs 13:17; $19: 32) i^{6}$ and (7) breastplate (Eph $\left.6: 14\right) .^{7}$

Bearing Arms in the New Testament

Jesus and the apostles in the New Testament did not sanction or condemn war. John the Baptist did not advise the soldiers to change their trade but only to be content

'Thomas, 22-24.

${ }^{2} 2$ Kgs 3:26; Neh 4:13; Pss 55:21; 59:7; Gen 3:24; $27: 40 ; 31: 26$.

${ }^{3}$ Judg $19: 29 ; 1$ Kgs 18:28; Josh 5:2, 3; Ezek 5:1, 2 . ${ }^{4} J u d g$ 5:8; 1 Sam 13:22; 17:7; 2 Sam 1:6.

${ }^{5} 1$ Sam 17:7, 41, 45; 2 Sam 8:7; Eph 6:16.

${ }^{6} \mathrm{Job}$ 41:28; Pss 11:2; 64:7; Isa 37:32.

${ }^{7} 1$ Tim 5:8; Lam 8:8. 
with their wages and avoid abuse of their power (Luke 11:2122). The New Testament employs such military terminology as legions of angels, sword, violence (Matt 26:52; 10:34;

\section{$11: 12$; Luke $16: 16 ; 22: 36 ; 14: 31-32) .^{1}$}

We must, however, note that since Jesus and His disciples neither endorsed nor condemned war directly, both sides of the combatancy issue take the sayings of Jesus and the apostles to support their own position. The principle upon which God established $\mathrm{His}$ kingdom in the New Testament is neither war nor force.

Jesus answered, My kingdom is not of this world: if my kingdom were of this world, then would my servants fight, that I should not be delivered to the Jews: but now is my kingdom not from hence. (John 18:36)

Although this text in no way abolishes war, it does forbid use of human temporal weapons to establish God's kingdom. ${ }^{2}$ In John 18:36 the preposition "of" in Greek (ek) means not only "from" or "originating from" but also the kingdom is not "of the side of" or belonging to (Gr. kosmos) the world. Barnabas Lindars puts it this way:

Jesus' kingdom is not a kingdom of the world of man apart from God but a kingdom of man in relation to God; not secular, but spiritual. For the kingdom understood in this way, military action is not appropriate, a fact

${ }^{1} \operatorname{Rom} 6: 13-14 ; 13: 12 ; 1$ Cor $9: 7,25 ; 2$ Cor $6: 7 ; 10: 3-6 ;$ Eph 6:11-18; Col 2:15; 1 Thess 5:8; 1 Tim 1:18; 2 Tim 2:35 .

${ }^{2}$ Black, 82 . 
which the church has not always remembered. ${ }^{1}$

Jesus' statement about His kingdom not being of this present world explains why He did not allow the use of force (sword) by His disciples during His arrest (John $18: 11) .^{2}$

The pulpit commentary asserts that

neither now nor at any future period will it \{Christ's kingdom $\}$ derive its origin from this world. So far as Christ is king, His royal power and state are not furnished by earthly force, or fleshly ordinances, or physical energies, or material wealth, or imperial armies. The dominion that He will wield will be one over hearts and lives; the authority of the Lord Jesus cannot be arrested or overpowered by physical force. ${ }^{3}$

Even in this present world, the kingdom of Christ is spiritual and not a temporal kingdom. His people are not expected to fight physically on behalf of His kingdom (Matt 26:52). The mission of God's people is to preach the gospel to all people of all nations (Matt 28:18-20; Rev 14:6-12; Acts $10: 34,35)$. By following Christ's example, we are to save lives through love and not to destroy (Luke 9:5, 6; Matt $22: 37-39 ; 2$ Cor $6: 4-6 ; 1$ Pet $2: 21-23$ ).

It must be noted that God authorizing combatancy in the OT and participating in war does not give His followers the right to be combatant. The simple reason is that God has not authorized the use of combatancy as a method of mission

'Barnabas Lindars, New Century Bible: The Gospel of John (London: Butler and Tanner, 1972), 558, 559.

${ }^{2}$ John $8: 23 ; 17: 16 ; 18: 36$.

3"Luke," The Pulpit Commentary, ed. H. D. M. Spencer (Grand Rapids: Wm. B. Eerdmans Company, 1977), 17:394. 
of the present-day church (Rev 14:6-12; Matt 28:18-20). Therefore, God's spiritual kingdom (His people), established by Christ's mission, does not involve combat; rather, it is to preach to all people in all corners of the world (Matt $13: 29,30,39 ; 28: 18-20 ; 26: 52$ Acts; $10: 34,35$; Rev 14:6-12;

John 18:36; Luke 9:56).

Christians not being combatant in the NT for the establishment of God's kingdom in no way minimizes their allegiance to state government. Probably the most used biblical argument in favor of Christians supporting governments is in the book of Romans.

Let every soul be subject unto the higher powers. For there is no power but of God: the powers that be are ordained of God. Whosoever therefore resisteth the power, resisteth the ordinance of God: and they that resist shall receive to themselves damnation. For rulers are not a terror to good works, but to the evil. Wilt thou then not be afraid of the power? do that which is good, and thou shalt have praise of the same: For he is the minister of God to thee for good. But if thou do that which is evil, be afraid; for he beareth not the sword in vain: for he is the minister of God, a revenger to execute wrath upon him that doeth evil. Wherefore ye must needs be subject, not only for wrath, but also for conscience sake. For this cause pay ye tribute also: for they are God's ministers, attending continually upon this very thing. Render therefore to all their dues: tribute to whom tribute is due; custom to whom custom; fear to whom fear; honor to whom honor. (Rom 13:1-7)

Allan A. Boesak, president of the World Alliance of Reformed Churches, holds the view that Roms 13:1-7 is not an unequivocal, unrelenting call for blind, unquestioning obedience to the state; neither does Roms 13:1 mean that the government of the day comes from God, but rather that the 
power, the authority which the government represents, is established by God. ${ }^{1}$

Frank Leo Finkbiner of the Southern California School of Theology affirms the above-mentioned position by saying that when Romans was written it was during the interval in which good government prevailed. ${ }^{2}$ The problem with this position is that God's almighty power is limited for He does not usually intervene directly and visibly in the selection of leaders. Other schools of thought hold to the belief that God established the government system or the institution of government and also appoints leaders. Regarding this position, Frank E. Gaebelein in The Expositor's Bible Commentary writes:

Paul makes a sweeping statement when he says: "There is no authority except that which God has established.' It is true even said of satan that what authority he exercises has been given him (Luke 4:6). God has ordained this tension between authority and submission. God has so arranged the world from the beginning at the creation, by all means, if you like as to make it possible to render his service within it; and this is why he created superiors and subordinates. ${ }^{3}$

${ }^{1}$ Allan A. Boesak, ed., Churches and Apartheid--A Call to Prayer: When Prayer Makes News (Philadelphia:

Westminster Press, 1984), 138-177. On June 16, 1985, a call was given to all South African churches to pray for the downfall of the government and this book was written as a result of that call.

"Nero," Encyclopedia Britannica (1953), 15:230, quoted in Frank Leo Finkbiner, Church and state from Paul--I Peter (Ann Arbor: University of Michigan, 1960), 20.

${ }^{3}$ E. Kasemann, "New Testament Questions of Today," The Expositor's Bible Commentary, 10 ed., ed. Frank E. Gaebelein (Grand Rapids: Zondervan Pub. House, 1976), 137. 
It is probably significant that the name of Christ does not appear anywhere in the passage. This school of thought does not move in the sphere of redemption or the life of the church as such, but in relation to the state that God in His wisdom has set up. While the Christian has his citizenship in heaven (Phil 3:20), the Christian is not, on that account, excused from responsibility to acknowledge the state as possessing authority from God to govern. The Christian holds a dual citizenship.

The problem with such a position is that wicked and inhumane dictators like Adolf Hitler, Iraq's Saddam Hussein, and Idi Amin (to name a few) become divinely appointed and ordained. Can we say that God only appointed the system of government without sanctioning the selection of leadership or do we believe that God appoints the system of government and selects the leaders? It appears that God places a limit on the power of leaders. Ellen white wrote:

The power exercised by every ruler on the earth is Heaven-imparted; and upon his use of the power thus bestowed, his success depends. To each the word of the divine watcher is, "I girded thee, thou hast not known Me" Isaiah 45:5. And to each the words spoken to Nebuchadnezzar of old are the lesson of life: "Break off thy sins by righteousness, and thine iniquities by showing mercy to the poor; if it may be a lengthening of thy tranquillity." Daniel 4:27. "To understand these things, --to understand that "righteousness exalteth a nation;" that "the throne is established by righteousness" and "upholden by mercy" (Proverbs 14:34; $16: 12$; 20:28); to recognize the outworking of these principles in the manifestation of His power who "removeth kings, and setteth up kings" (Daniel 2:21),this is to understand the philosophy of history. In the word of God only is this clearly set forth. Here it is shown that the strength of nations, as of 
individuals, is not found in the opportunities or facilities that appear to make them invincible; it is not found in their boasted greatness. It is measured by the fidelity with which they fulfill God's purpose. ${ }^{1}$

since the power of rulers is "sanctioned" by God, it is essential that every soul be subject to "obey" the higher powers. The word "obey" in this verse is also very interesting. Paul here uses hupotasso instead of his more usual hupakouo. The latter expresses a clear and unqualified obedience that the Christian owes to God. The displacement of hupnakouo by hupotasso, according to Boesak, "is not accidental." It deliberately underlines Paul's point that there is a significant difference between the obedience due to God and obedience due to rulers. ${ }^{2}$ The former is optional: hupakouo is the obedience due to God. Hupotage (the noun related to hupotasso) is that realistic regard for the daily orderings that is a prerequisite necessary for the humanness of the world. Lehman writing about these differences stated: "'Hupotassestho,' translated as 'order yourself under' instead of submit, rescues submit and submission from time honored association

${ }^{1}$ Ellen G. White, Education (Mountain View, CA: Pacific Press Pub. Assn., 1952), 174, 175.

${ }^{2}$ Boesak, 146 . 
with passivity and gives them a meaning at once more active in purposed." 1

Granfield, in his shorter commentary on Rom 13, wrote about vs.1 that "the most interesting expression here is 'be subject.' It is clearly a key word in this section. It is often assumed that the Greek verb translated 'be subject' means 'obey.'"2 But the Greek verb used is not the obvious verb to use to express the meaning "obey". There are in fact three other Greek verbs that occur in the New Testament which do mean precisely that. It seems likely that paul deliberately chose to use this particular verb here because he felt it suited his intention better than the other verbs. In Eph 5:21, Paul uses the same verb hupotasso for "submitting yourself one to another in the fear of christ." The meaning of hupotasso is quite clearly stated. For here it denotes a reciprocal obligation, and obedience cannot be reciprocal. (See also Rom 12:10; Phil 2:3.) It seems certain that in the present verse what Paul is enjoining is not blind obedience to whatever command the authority may decide to give, but the recognition that one has been placed below the authority by God.

Paul seems to have in mind a state in which the

${ }^{1}$ Paul Lehman, Transfiguration of Politics (New York: Harper and Row, 1975; London: H. Greenwood and Co., 1979), 302-303.

${ }^{2}$ Charles Granfield, Romans: A Shorter Commentary (Grand Rapids: Eerdmans Publishing Co., 1985), 320. 
Christian's "subjection" (respect, obedience) to the authorities is limited, so far as such obedience does not conflict with God's laws. A Christian is obliged to pay taxes willingly, since no government can function without resources. Paul's underlying principle here is that a Christian must be noted as an excellent example in obeying. what is right for the state, society, and the government. The statement "Let every soul be subject unto the higher powers; for there is no power but of God; The powers that be are ordained of God" (Rom 13:1) does not imply that God always approves the conduct of civil government, nor does Paul mean it is the Christian's duty always to submit to them. The requirements of government may at times be contrary to the law of God, and under such circumstances it is good to obey God rather than man (Acts $4: 19 ; 5: 29$ ). Paul's point, according to the Seventh-day Adventist Commentary, is that the ruling power of human governments is entrusted to men by God, according to His purpose for man's welfare. The Christian will support the authority of the existing state. He will not presume to take it into his own hands to resist or to depose "the powers that be."1 Such instruction was especially needed in Paul's day, for at that time the Jews were in a turbulent mood and had already

1"Romans," SDA Bible Commentary, ed. F. D. Nichol (Washington, DC: Review and Herald Pub. Assn., 1953-57), $6: 626$. 
stirred up rebellion in various parts of the Roman Empire. For Christians to reveal a similarly unsubmissive spirit would have been to incur the same displeasure that was beginning to fall upon the Jews. It would also have resulted in their forfeiting the protection of the Roman state, which had often been a blessing to the early Christians as Paul could testify from his own experience (Acts 22:24-34).

Furthermore, it would have brought reproach upon the Christian church and its message of peace and brotherly love. Therefore, Paul elsewhere urges believers to pray for those in authority ( 1 Tim 2:1, 2) and to obey them (Titus 3:1). Likewise, Peter commands Christians to submit "to every ordinance of man for the Lord's sake" (1 Pet 2:1317). ${ }^{1}$

Hodge added to this conclusion this way:

It is clear that this passage (vs 1, 2) is applicable to men living under every form of government, monarchical, aristocratical, or democratical, in all their various modifications. Those who are in authority are to be obeyed within their sphere, no matter how or by whom appointed. The extent of this obedience is to be determined from the nature of the case. They are to be obeyed, as magistrates, in the exercise of their lawful authority. ${ }^{2}$

God, the creator, the owner of all things, appoints a system of government in which man must have a governing body in

${ }^{1}$ Ibid. , 627.

${ }^{2}$ Charles Hodge, Commentary on the Epistle to the Romans (New York: Williams S. Martien, 1846), 307. 


\section{3}

order to keep things in order. Wicked and terrible leaders may arise because of the power of choice. He has given to man, but man must not worry or give up because through the play and counterplay of man God's will is still carried out. A Christian, knowing that God will work all things together for good, must not resist leadership but work in harmony with leadership. Since Paul's conscience was sealed with doing what is right in the sight of God it does not really matter what form of government is in power. As long as its rules do not go contrary to the law of God, the Christian will subject him/herself to it. True Christianity involves honoring whatever is right in the sight of God. It may end in death, but to an honest Christian "to die is gain to live is Christ" (Phil 1:21).

The design of the civil government is not to promote the advantage of rulers. They are ordained and invested with authority to be a terror to evil-doers and an encouragement to those who do well. Rulers are the ministers of God to this end, and are appointed for this very thing. On this ground rests our obligation to obedience, and the obligation ceases when this design is systematically, constantly, and notoriously disregarded. While unfaithfulness on the part of the government exists, or where the form of government is incompatible with the design of its institution, the governed must have a right to remedy the evil. But they cannot have the moral right to 
remedy one evil by the production of a greater evil.

"Wherefore ye must needs be subject, not only for wrath, but also for conscience sake" (Rom 7:5). Here, the thought is that the morally responsible person and good citizen will recognize the need for the government in society as a divine ordinance. Resistance to this divinely ordered authority will provoke in such a person a pang of conscience, and prospect of such moral discomfort as should dissuade from civil disobedience. In this role, conscience can serve as a positive guide of moral conduct, hence of responsibility, consciousness and obligation.

J. Lyth wrote:

The Christian's subjection to the civil authority is a) necessary, because it is a divine ordinance, and essential to the general good, b) obliging, not only for wrath, but for conscience sake and c) complete, because it is willing, sincere and conscientious. ${ }^{1}$

The reasons given for submission in Rom 13:1-7 are twofold: (1) obedience to law in general, and (2) payment of all dues. For a human being, the question to ask is, Can society exist without law or law-enforcement agencies? since the answer is no, then although some governments may be viewed as utilitarian in nature, most of the laws are good if we obey them. It is, therefore, appropriate that we pay respect to the government authorities, for here we are

'J. Lyth, "Christian Subjection to the Civil Authority," in Biblical Illustrator, ed. Joseph S. Exell (Grand Rapids: Baker Book House, 1957), 41:569. 
not only contributing to the government functions but also we are contributing to our own protection. A Christian must not worry about how the tax money is being used, for such things are beyond our reach, except as voting, or other participation in government is legal. Rather, a Christian must exercise a greater loyalty to a system of leadership that is God-ordained. We must do our part as loyal citizens and follow the example of Jesus, who although He knew the corruption of the government of His time, still made Peter pay his share of the taxes. The Lord also made it clear that we must give to Caesar what belongs to Caesar and to God what belongs to God.

By supporting the civil government with their tribute, the Christians were acknowledging that they owed obedience to the state as ordained of God "for the punishment of evildoers, and for the praise of them that do well" ( 1 Pet $2: 14)$. The theme of the epistle to the Romans is the universal sinfulness of man and the universal grace of God in providing a way by which sinners may not only be pardoned but restored to perfection and holiness. The way is faith in Christ. Paul's application of the doctrine of righteousness by faith includes a Christian's subjection to authorities and his duty as a member of the society. Christians must subject themselves to the social government and obey the rules of the authorities because God has chosen both to sustain the government and the leaders of 
government. Our allegiance to the state, however, does not permit us to disobey God's law (Acts $4: 19 ; 5: 29$ ). When it comes to bearing arms and using them to kill other people for the sake of the government, Seventh-day Adventists are not encouraged to bear arms. As noted already, the NT forbids war in order to establish God's kingdom. The universality of the church (Matt $28: 18-20 ; 24: 14$ ) also prevents Christians from fighting. The strong recommendation for christian participation in military service is that it is better limited to noncombatancy. It is always better to stand for God rather than man.

The Ghanaian Seventh-day Adventist Chaplain and the Question of Bearing Arms

Seventh-day Adventists in the Ghana Armed Forces and the Bearing of Arms

The Seventh-day Adventist Church highly recommends its members not to enter military service voluntarily if they have convictions against bearing arms or performing routine military training or duty on Sabbath. Since about 90 percent of the SDA's the Ghana Armed Forces were not Seventhday Adventists before joining the army, it is recommended that they make every effort not to bear arms. The chaplain should state the Seventh-day Adventist recommendation concerning the bearing of arms. The recommendation is not to bear arms but to participate in war as a noncombatant but the Seventh-day Adventist military person must make a personal decision in terms of the options given in appendix F. 
In case there is war, the chaplain must pray that the Holy spirit will help each individual in the military to stand for what he or she believes to be the right thing to do. The chaplain can recommend that Seventh-day Adventists attempt to change their duty to the medical field (nursing assistant, registered nurse, laboratory technician, medical doctor), or chaplaincy (if called to ministry), neither of which require bearing of arms.

Advice to Seventh-day Adventists Regarding the Ghana Armed Forces

Since joining the Ghana Armed Forces is purely on a voluntary basis, the chaplain can counsel seventh-day Adventist members not to enter the military service if they are conscientious objectors (noncombatant).

The Adventist Church strongly counsels its members not to enter military service voluntarily if they have conscientious beliefs that they cannot bear arms or be available for routine military training or duty during Sabbath hours. ${ }^{1}$

one may, however, join the military as a medical cadet or chaplain (p. 26).

\section{Diet}

The Ghana Armed Forces usually supplies food to its military personnel while they are on duty. Most times their

${ }^{1}$ National Service Organization, General Conference of Seventh-day Adventists, "What an Adventist Should Know About the Military," Washington, DC: General Conference of Seventh-day Adventists, n.d., 2 . 


\section{8}

food contains unclean meat. ${ }^{1}$ since they do not have a variety of food, the Seventh-day Adventist seems to have no choice. The Adventist chaplain has to deal with the issue concerning diet, especially in relation to survival training in which the army personnel are required to eat snakes, snails, and other unclean meat.

The Seventh-Day Adventist belief on diet is based on the fact that the body is the temple of God. "Know ye not that ye are the temple of God, and that the spirit of God dwelleth in you? If any man defile the temple of God, him shall God destroy; for the temple of God is holy, which temple ye are," (1 cor 3:16-17).

Therefore the church recommends that its members care for their bodies intelligently, with adequate exercise and rest. We must adopt the most healthful diet possible and abstain from the unclean foods identified in the scriptures.

To the first couple, the creator gave the ideal diet: "I give you every seed-bearing plant on the face of the whole earth and every tree that has fruit with seed in it. They will be yours for food" (Gen 1:29, NIV). After the

${ }^{1}$ For unclean meat the term tame is its equivalent in Hebrew, which is defined as defiled, infamous, polluted. Animals are clean or unclean by nature. Gen 7:2 speaks of clean and unclean animals with Noah. The unclean which are listed in Lev 11 include camel, hare, and swine, vss. 1-8; sea creatures without fins and scales, vss. 9-12; birds such as raven and vultures, vss. 13-19; other animals like mice, lizard, and weasels, vss, 29-31. Also Deut 14:3-21. David Harris, "Tame," Theological Wordbook of old Testament, ed. Laird Harris (Chicago: Moody Press, 1980), 1:349. 
fall, God added to their diet "the plants of the fields" (Gen $3: 18$, NIV).

Today's health problems tend to center on the degenerative types of diseases that are directly traceable to diet and lifestyle. The diet God planned, consisting of grains, fruits, nuts, and vegetables, offers the right nutritional ingredients to support optimum health.

Only after the flood did God introduce flesh as food. With all vegetation destroyed, God gave Noah and his family permission to eat flesh foods, stipulating that they were not to eat the blood in the meat (Gen 9:3-5).

scripture implies that God told Noah and his family that they were to eat only what He identified as clean animals. Because Noah and his family needed the clean animals for food as well as for sacrifices (Gen 8:20), God instructed Noah to take seven pairs of each kind of clean animal, in contrast to only one pair of each kind of unclean, with him into the ark (Gen $7: 2,3$ ). Lev 11 and Deut 14 provide extensive expositions on clean and unclean foods.

By nature, unclean animals do not constitute the best food. Many are either scavengers or predators--from the lion and swine to the vulture and the bottom-dwelling, sucker-type fish. Because of their habits they are more apt to be carriers of disease.

Studies have revealed that in addition to the moderate 
amounts of cholesterol found in both pork and shellfish, both foods contain a number of toxins and contaminants which are associated with human poisoning.

By abstaining from unclean foods, God's people demonstrated their gratefulness for their redemption from the corrupt, unclean world around them (Lev 20:24-26; Deut 14:2). To introduce anything unclean into the body temple where God's Spirit dwells is less than God's ideal.

The New Testament did not abolish the distinction between clean and unclean flesh foods. Some believe that because these dietary laws are mentioned in Leviticus, they are merely ceremonial or ritualistic, and so are no longer valid for Christians. Yet the distinction between clean and unclean animals dates back to Noah's day--long before Israel existed. As principles of health, these dietary laws carry with them an ongoing obligation.

Reqularity, Simplicity, and Balance

Successful dietary reforms are progressive and must be approached intelligently. Eventually, we should learn to eliminate, or use only sparingly, foods with high fat and/or sugar content.

Furthermore, we should prepare the foods we eat in as simple and natural a way as possible, and for optimum benefit, should eat at regular intervals. Complex, stimulating diets are not the most healthful. Many condiments and spices irritate the digestive tract, and 
their habitual use is associated with a number of health problems.

The chaplain should contact the commanders for special exemptions from unclean food using the Freedom of Religion Act in the Ghana Armed Forces (see also page 27, 28). At the same time, the chaplain can advise his or her people to stand firm in their beliefs in case the commanders refuse.

\section{other Issues}

other issues may arise as the Seventh-day Adventist chaplain begins and continues his work. The principles that one must use in dealing with every issue is to determine that the requirement does not contradict denominational beliefs as based on the Bible and the spirit of Prophecy. If the rule is not in conflict with the Bible, he should try to follow the rule to the letter and spirit of that regulation.

Chaplains must be humble, but have a firm determination when there is a need to contact the commanders of the barracks regarding a problem concerning any Adventist military person.

With the blessing of God, the chaplain must remember that success will happen amid trouble. 
CHAPTER V

SUMMARY AND RECOMMENDATIONS

\section{Introduction}

The purpose of this chapter is to give a summary, conclusions, and recommendations for this dissertation.

\section{Summary}

The dictionary defines chaplain as a "clergyman officially attached to the army, navy, court, some public institution; or to a family to conduct religious exercises."

Since the main mission of the Seventh-day Adventist church is to preach the gospel to all nations, peoples, and tongues, we must not exclude any group or profession.

"Evangelism, the very heart of Christianity, is the theme of primary importance to those called to herald God's last warning to a doomed world." 2

Christ's last words to his disciples 'Go ye therefore and teach all nations,' go to the farthest bounds of

${ }^{1}$ Webster's Third New International Dictionary of the English Language (1986), s.v. "Chaplain."

${ }^{2}$ Trustees of Ellen G. White Publications, preface to Evangelism, by Ellen G. White (Washington, DC: Review and Herald Pub. Assoc., 1974), 5. 
the habitable globe, and know wherever you go, that My Presence will attend to you . . . To us also the commission is given. We are bidden to go forth as Christ's messengers, to teach, instruct and persuade men and women to urge, upon their attention the word of life. 1

The military is one of the world's largest professions. since the fall of man, war has been a reality, hence every nation throughout history has had some form of military establishment. In the OT, war was a reality. Everyday life in oT times involved war, worship, and work.

God used the patriarchs, prophets, and priests to perform chaplain-like functions in the OT. Thus, views for or against the justice or injustice of war do not, in principle, argue against military chaplaincy. Military persons and their families who participate actively in the defense of their country must be given the opportunity, through chaplaincy ministries, to hear the good news of salvation.

In both the OT and NT there is enough evidence to conclude, therefore, that chaplaincy ministries are the necessary tools of bringing salvation to all military personnel. In NT times, military personnel were not condemned because of their profession; but they were admonished to be careful of how they exercised their power.

${ }^{1}$ White, Evangelism, 15. 
John the Baptist, the Lord Jesus Himself, Peter, and Paul ministered to soldiers.

It took almost eight years for the Adventist church to move from total opposition to military chaplaincy (see appendix A) to total acceptance and the recommendation for Adventist ministers to join the armed forces as chaplains, took the Adventist Church almost eighty years.

Now there are many Seventh-day Adventists in Africa who are in the military service. In Ghana, the number and influence of these Adventist military personnel have been felt by the armed forces, although not without opposition and problems. Now the Ghana Armed Forces have requested that the Ghana Seventh-day Adventist Conferences recommend personnel as chaplains in the armed forces.

In this dissertation I have suggested ways by which Seventh-day Adventist chaplains could be recruited to join the Ghana Armed Forces and have proposed a manual which will enable the church to establish chaplaincy ministries in the Ghana Armed Forces. This manual contains instructions for Seventh-day Adventist members who are considering serving as chaplains in the Ghana Armed Forces and for Seventh-day Adventist Conferences in Ghana as they consider sending chaplains to lead in the establishment of chaplain ministries. It contains the church's expectations of Adventist chaplains in the military. The manual also deals with military regulations, customs governing the placement 
of chaplains in the Ghana Armed Forces, status of chaplains, entry prerequisites, promotion, pastoral ministries, and religious program organizations.

The crisis-ministries counseling method suggested in the manual will provide chaplains with the needed commencement methodology to deal with such issues as grief, divorce and remarriage, family, mental disorders, alcoholism, addiction, marital problems, premarital counseling, physical illness, violence and abuse, and choosing marriage partners.

A careful study of the problem of combatancy is given in the manual. The Seventh-day Adventist position on bearing arms, which is non-combatancy, is defined. ${ }^{1}$ The manual also deals with military diet, the Sabbath, and other issues. Hopefully this manual will serve as a reference material for the Africa-Indian Ocean Division of the Seventh-day Adventist Church in establishing chaplaincy ministries in the Ghana Armed Forces and other African countries within the jurisdiction of the African-Indian Ocean Division.

${ }^{1}$ The issue of non-combatancy deals with the following: (1) The history of the Seventh-day Adventist position on the bearing of arms, (2) the bearing of arms in the OT, (3) Christian allegiance to the state government; and (4) advice that a chaplain could give to a Seventh-day Adventist who wants to join the Ghana Armed Forces (see pages dealing with non-combatancy in chapter 4 ). 


\section{Recommendations}

A recommended sequence for placing Seventh-day Adventist chaplains in the Ghana Armed Forces and the internal procedure for placing Adventist chaplains is:

1. The church needs to seek pastors who have the talent and maturity for and are willing to be military chaplains. Such pastors should accept and pass the physical training needed to be accepted as officers in the Ghana Armed Forces. They must also fulfill all the entry prerequisites as listed under the status of the chaplain.

2. The individual must be ordained or commissioned by the church before applying for the position of a chaplain in the Ghana Armed Forces.

3. The church must recommend the chosen individual to the Ghana Armed Forces officers Personnel Department, which will forward the application of the church appointee to the Ghana Armed Forces Chaplain General Headquarters. The individual will then be appointed and sent to physical training camp and then to the Ghana Armed Forces officers School at the Teshie Camp in Accra.

4. The old image of the Ghana Armed Forces as a brutal, oppressive, and violent force has changed considerably over the years (see p. 43 for information on the old and new image of the Ghana Armed Forces). The new 
image must be made a basis for appealing to young pastors to consider becoming chaplains in the Ghana Armed Forces. ${ }^{1}$

5. The conferences must sponsor some of the enlisted personnel to pursue a four-year college degree program in religion and theology at Valley view college with the aim of letting such a person become a chaplain in the Ghana Armed Forces. ${ }^{2}$

6. Ghanaian theological students in seventh-day Adventist institutions in England, India, the Philippines, West Indies, and United States should be encouraged to diversify with studies in chaplaincy as a choice.

7. A course of study in chaplaincy must be offered at Valley View College in Ghana using the manual I prepared as a source material to create awareness in young pastors regarding the importance of becoming chaplains in the Ghana Armed Forces. ${ }^{3}$

${ }^{1}$ As noted in the pages dealing with "Potential for Growth" and "Seventh-day Adventist Attitude Towards Military Chaplaincy," the Burma Camp Seventh-Day Adventist Church request to the Ghana Armed Forces to provide them with chaplains has been granted. The armed forces are eagerly waiting for the Seventh-Day Adventist Church to recommend a chaplain to them.

${ }^{2}$ The Ghana Armed Forces is willing to allow any enlisted Adventist who will study theology in an Adventist school with emphasis in military chaplaincy to go to such studies without losing seniority.

${ }^{3}$ I had a face-to-face discussion on this issue with the chairman of the Theology Department of Valley view College, at the James White Library, Andrews University August 21, $1997,7: 00$ p.m., and have been invited to teach this course during the summer after completion of this dissertation. 
8. The conferences must start a recruiting campaign to get young and dedicated men to take up the work of chaplaincy. This recruiting could be done by a person in the new office suggested in \#9 below.

9. The West African Union and the Africa-Indian Ocean Division need to create Adventist Chaplaincy Ministries positions at each level to coordinate with the General Conference Adventist Chaplaincy Ministries office. This chaplaincy department will not only be necessary to recruit and coordinate military chaplains but also chaplains for colleges, universities, police departments, hospitals, and prisons (correctional institutions).

10. The following should be added to this material in process of working with the government and the church on this issue of chaplaincy: (a) Credential: The issue of who issues credentials and what credentials are necessary for chaplaincy service. (b) Church authority and control of chaplaincy ministries in the Ghana Armed Forces. (c) Endorsement. (d) Service credit, record and retirement issues. (e) Chaplains re-entry into civilian pastoral work. (f) Wage scale. 


\section{APPENDIX A}

\section{LETTERS}

(The materials in this appendix are reproduced because photocopies were in poor quality) 
Chaplain Service Directorate

Ministry of Defense

Burma Camp

ACCRA

ACCRA: 76111 Ext: 2082

6th May, 1986

MOD $/ 14022 / \mathrm{CH}$

See Distribution

Holding of Church Services other Than the Authorized Places of Worship in the Barracks

Reference: Army/6471/A/PA2 dated 27th Jan 1982.

Force/5013/2/G (OPS) dated 27th Feb 1986.

1. It has, sadly, come to the notice of this

directorate that our directives on the interpretation of

reference $B$ on the spirit of accommodation regarding other

Christian churches in the military has met with opposition and antagonism.

2. This state of affairs is not only unfair and uncharitable but also religiously indefensible.

3. All Chapels in the barracks are the property of the Ministry of Defense and the fact that our peculiar economic predicament had compelled the Ministry to withhold financial and relative assistance to the churches does not therefore make chapels the property of any one denomination.

4. From the above it is directed that with effect from Saturday May 10th 1986;

whole day.

a) The SDAs have the use of the unit chapel- the

b) Tuesday - from 1830-2030 hrs.

c) Friday - from 1830 - $20.30 \mathrm{hrs}$.

All other days and timings not referred to here are for the Methodists and Presbyterians.

5. Accept from strict compliance in the interest of Christians ecumenist.

Sgd ??????

MDK Kumesi

Lt $\mathrm{Col}$

Director Chaplaincy Services

Distribution:

Methodist/Presbyterian Church - 5BN

Burma Camp SDA Church

Information:

External:

$5 B N$ 
131

Chaplain 5BN you are to see to strict compliance to this directive.

MOD/14022/CH Chaplaincy Service Directorate, Ministry of Defense, Burma Camp, Accra 
GHQ $14020 /$ RA

Chaplain General's Department General Headquarters

Ghana Armed Forces

Burma Camp

ACCRA 77611 Ext 2082

December 1990

GHQ (PA)

Recognition of Religious Bodies in the Armed Forces

1. The Chaplain General's Department was established in 1968 under certain policy guidelines which include the following:

a) Any religious body with 1000 (one thousand) service personal belonging to it shall be given official recognition to enable the said body to operate as a church in the armed forces.

b) The head of religious body so recognized shall be invited to recommend an ordained priest/pastor of the said body for appointment as chaplain in the armed forces.

2. The Department has since her establishment been carefully guided by Paragraph 1 , and qualified for recognition at that time, continue to qualify. The Quarterly Religious Numerical Returns which are sent to my Department and compiled for the guidance of manpower planning at the office of DG PA, consistently confirm this. The religious bodies which continue to qualify include the following:

a) Roman Catholic Church

b) Methodist Church

c) Presbyterian Church of Ghana

d) E. Presbyterian Church

e) Anglican Church

f) Muslim

3. Somehow, over the years, some other religious bodies here found themselves in the armed forces operating as churches, etc., without prior authorization, i.e., RECOGNITION BY ARMED FORCES before commencement of their operations. This, I consider highly irregular, considering that altogether we have on record a total of 24 (twentyfour) other churches, etc., to which various service personnel belong. They include:
a) Apostolic Revelation Society
b) Musama Disco Christo Church
c) Lite study Fellowship
d) Salvation Army
e) Church of the Pentecost
f) Church of the Lord (Aladula)
g) Church of Bethany
h) Seventh-day Adventist Church
I) Church of Christ 
j) Assemblies of God

k) Apostolic Church

1) Mystery School

m) Universal Church

n) Rosicrucian

o) Buddhist

p) A.M.E. Zion Church

q) Baptist

r) Deeper Life

s) True Church

t) Church of Rome

If each of these churches should resort to arbitrary actions and get herself entrenched in the armed forces, the situation will certainly be unbearable and will create an unpleasant atmosphere. Not only that, we would have acted in an undisciplined manner contrary to what our profession demands of us.

4. However, I am glad to mention that out of the churches mentioned in para 3, the Church of the Pentecost has been identified as one that has steadily been increasing in number. Incidentally, the church of the Pentecost belongs to the Pentecostal Council of Ghana and so are many of the others on the list in para 3. Using the example of the present Methodist/Presbyterian Church in the armed forces which is a conjunction of three churches, i.e., Methodist Church, Presbyterian Church of Ghana, and Evangelical Presbyterian Church, even though each one of those churches should be encouraged to come together for worship.

5. In the light of the above, I make the following recommendations:

a) That the Pentecostal Churches mentioned in paragraph 3 be permitted to come together for a combined worship during this Christmas and the New Year. This will enable this Depart. to make an assessment upon which a recommendation for recognition can also be made.

b) That apart from the recognized churches mentioned in paragraph 2 above, all churches operating in the armed forces without the following:

i. Application from Recognition

ii. Chaplain General's Recommendation

c) Official recognition by General Ho should stop operating in the armed forces with effect from ist January 1991. 
sir.

6. The above is submitted for your study and action,

William Jonfia

Colonel

Chaplain General ${ }^{1}$

'GHO/14022/RA. Chaplain General's Department, General Headquarters, Ghana Armed Forces, Accra, Ghana, letter dated December 1990. 
Reference No. 5BH/164/A

5 Infantry Battalion Arakan Barracks

Burma Camp

ACCRA

Tel 776111 Ext 2211

7 th January 1991

The Church Elder

SDA Church

Arakan Barracks

Burma Camp

RECOGNITION OF RELIGIOUS BODIES IN THE ARMED FORCES Reference: GHQ/14022/RA dated 20 December 1990 (Copy attached)

1. By a copy of the letter attached, you are kindly informed that you have not been recognized officially by General HQ to operate in the armed forces.

2. It would therefore be improper if this unit contravenes the regulations laid down by the armed forces pertaining to religious affairs and allows you to continue operating in the barracks.

3. It is requested from the forgoing that you terminate your operation in our barracks as from saturday, January 5, 1991, until you are properly recognized by the armed forces.

4. Please acknowledge and comply with the contents of this letter and that of the reference letter attached.

\author{
J. A. Aphour \\ Lieutenant \\ For Commanding officer ${ }^{2}$
}

${ }^{2} 5 \mathrm{BN} / 164 / \mathrm{A}$. Chaplain General's Department, Ghana Armed Forces, General Headquarters, Accra, Ghana, dated January 7, 1991. 
APPENDIX B

RECOGNITION OF RELIGIOUS BODIES PETITION 
BS/SDA $/ 2 / 91$

Seventh-day Adventist Church

Burma Camp

C/O PO BOX 9606

Airport, Accra

21st January, 1991

GHQ (PA)

RECOGNITION OF RELIGIOUS BODIES IN THE ARMED FORCES

PETITION OF SEVENTH-DAY ADVENTIST CHURCH IN BURMA CAMP

Reference:

A. 5BN/164/A dated 7 January 1991

B. GHQ/14922/RA dated 20 December 1990

C. MOD $/ 14022 / \mathrm{CH}$ dated 6 May 1986

D. 5BN Part one orders Serial No 113 dated 11 January 1986

E. MOD $/ 14022 / \mathrm{CH}$ dated 23 April 1985

F. Force/6471/A (PA3) dated 17 April 1985

G. MOD/6268/PSI dated 12 April 1985

H. AFR (Vol 1) Art. 33.01 (1) (d)

The Seventh-day Adventist Church members at Burma Camp have been stepped from operating from our normal place of worship by letter 5BN/164/A dated 7th January 1991 attached as Annex "A."

The above Annex "A" derived its authority from the Chaplain General's letter, ref "B" attached as Annex "B."

The church members therefore humbly petitioned as follows :

1. That par 5b of the Chaplain General's, letter ref B or Annex "B" does not apply to the SDA Church since our application for recognition, the chaplain General's recommendation and the official recognition by $\mathrm{CHQ}$ are met in Ref $C$ or Annex "C."

2. That noting the increasing number of seventh-day Adventists at Burma Camp, including senior officers, the church made approaches to get the members organized for worship at Burma Camp.

3. That this was in part at least to mitigate the extreme inconvenience and expenses the officers and men with our dependents were experiencing in meeting our spiritual needs.

4. That the Burma Camp in general, should also benefit from the health outreach programs of the worldwide Adventist Church.

5. That the result was the members formal application (pursuit to earlier discussions and petitions) to get so organized and announce our presence through an evangelistic campaign at the barracks in April 1985.

6. That DG(PA)'s letter Ref E or Annex "G" copied to the Chaplain General's office was submitted to GHQ on behalf of the church.

7. That this was duly approved . . Ref $F$ or Annex "F" and the Chaplain General's President directives to the 
approval in Ref E or Annex "E."

8. That the result was the establishment of the Seventh-day Adventist Church at Burma Camp in 1985. Our present strength is 382 in Accra and 237 in our stations, making a total of 619 as per Annex H.

9. That the church started worshiping in a classroom block at Chiringa until Force HQ directive Ref Force 5013/2/G(OPS) dated 27 Feb 1986 was issued.

10. That for the abundance of caution further permission was sought to enable the church to lawfully worship at the Burma Camp and in a recognized place of worship.

11. That this request was duly grated by the chaplain General's Department on the basis of the recognition granted by Force.

12. That $C O$ 5BN part one orders dated 11 June 1986 as can be seen in Ref $D$ or Annex " $D$ " confirmed the right of the SDA Church at Arakan Chapel on designated had other days for their worship.

13. That the joint use of the unit chapel at Arakan with our sister church had initial misgivings. Though your petitioners day and times of worship namely: Saturdays whole day; Tuesdays later changed to Mondays from 18.30 to 20:30 hrs and Fridays from 18:30 to 20:30 hrs, made a harmonious and more efficient use of the mob property as if served wider interest at no extra cost.

14. That the "recognition" of your petitioners was never respect and accommodation of the national policy guaranteeing religious tolerance, and there was the need to sift the genuine worshipers from dissidents.

15. That what your petitioners have had to occasionally experience is the issue of uneasy relationship in the use of the chapel as your petitioners numbers and contributions to life in the camp has been relatively commendable.

16. That the force recognition of your humble petitioners presence and rights to worship at the camp have always been defended by the supervisory offices notable GHQ(PA) Chaplain General, CO SBN and GHQ.

17. That the Chaplain General's letter Ref $C$ or Annex "C" reflects the real problem and respectfully submitted. afforded a lasting solution.

18. That your petitioners believe that the chaplain General's office still subscribes to the spirit of accommodation regarding other Christian churches in the military in interpreting the rules as it notable upheld in Ref C or Annex "C."

19. Further the one that is at variance with this spirit in the words of the Chaplain General's letter, may be said to be "unfair, uncharitable and religiously indefensible."

20. That having been this established, accommodated, 
defended and protected by Ref $c$ and Annex "c," your petitioners have in their humble way enriched the camp, not only spiritually, but also physically and as well as socially.

21. That among others petitioners cite:

a) Sponsorship of a team of five medical doctors plus some para-medical personal not only to give FREE public health education but also to treat cases and offer counsels on diabetes, hypertension, family planning, dental and diet from 6th to 29th June, 1990 at Arakan Barracks.

b) One-week educational program on dangers of smoking and how to stop smoking in five days.

c) Six months voluntary work to promote sanitation in the camp by desalting all drains in 1988 .

d) C 200,000.00 work of good a contributed to the up-keep of the inmates at the Ghana Legion.

e) C 150,000.00 worth of food items to the patients in children's ward at Military Hospital in 1988 .

f) Six months tree planting program at the congo Junction in 1988 to improve the environment.

g) Visit to the Dzorwulu special school with food

items worth about C 200,000.00 for the inmates and

led by the current chaplain General in 1989.

22. That it is your petitioners submission that we are adequately covered by paragraph 5b or the Chaplain General's supportive letter of 20 th December 1990(Ref B or Annex "B").

23. That from GHQ through the Chaplain General's Department your petitioners have been permitted, defended and protected through the chain of command. Your

petitioners have, infected you beyond the permissive state into holding discussions with the Chaplain General and logistics for a parcel of land at the chapel square for erection of a chapel building with contributions made by the members.

24. Further, that moves had long been made with the guidance of the chaplain General to get a chaplain for the Adventists.

25. That to that effect, the SDA Chaplain General of the worldwide headquarters of the church in USA visited the country and paid a courtesy call on the Chaplain General of the Ghana Armed Forces and had further discussions on the issue.

26. That your petitioners sincerely believe that the annexed correspondence and the informal meeting thereon, were not and could not be readily available when the list was made hence our advert inclusion in para 3 or Ref $B$ or Annex "B."

27. That the Chaplain General personally confessed before Lt. Col. Isaac Buabeng and Lt. Col. Fred Opuni-Mensah at his house on 2nd January 1991 and again at the house of DG(PA) on 10th January 1991 that it was by mistake that the 
SDA Church was mentioned in para 3 of Ref $B$.

28. That it is the earnest desire of your petitioners that we be given a parcel of land to help met the chapel needs of the Christian community.

29. That having regards to our deneguous structure with senior officers and men the decision be reviewed to harmonize with earlier decision of GHQ, Chaplain General's Dept and CO SBM.

30. That this will certainly reflect the forces pragmatic approach to problem solving and consistency in decision making. that:

In conclusion, your humble petitioners request to state

a) We applied, were recommended, recognized and accommodated in 1985.

b) That we be authorized to operate in barracks as provided by Ref $\mathrm{H}$ above.

c) That we be granted a parcel of land erect our own chapel for worship.

d) That we be provided with a chaplain to promote the moral and spiritual welfare of the Adventist service personnel and our families.

I. Buabeng

Humbly submitted

Lt Col

F. Opuni-Mensah

Lt Col

FOR AND ON BEHALF OF THE SDA CHURCH - BURMA CAMP ${ }^{1}$

${ }^{1} \mathrm{BC} / \mathrm{SDA} / 2 / 91$. Seventh-day Adventist church, Burma Camp, Accra, Ghana, letter written on 21st of January 1991 and re-mailed again on 9th January 1992 to the General Headquarters of the Ghana Armed Forces. 
APPENDIX C

RECOGNITION OF SDA CHURCH 
General Headquarters (PA)

Ghana Armed Forces

Burma Camp

Accra

Accra 776111 Ext 2934

25 August, 1992

GHQ/6167/PSI

RECOGNITION OF CHURCHES SEVENTH-DAY ADVENTIST (SDA)

Reference:

A. GHQ/14012/RA dated 5 May 1992

1. I am directed to inform you that the seventh-day Adventists have been given official recognition to operate as a church in the armed forces.

2. I am further directed to request you to issue appropriate instructions to enable the church to use one of the Garrison churches for worship on Saturdays. The church is to cease worshiping in barracks residence immediately. The military police have been authorized to stop any such worship and bring offenders to book.

3. The application of the church for a plot to construct a chapel is receiving attention and a synopsis Board will soon be convened to make recommendation for the GOC's approval.

$$
\text { P. Anim-Adjei }
$$

Mg Cdr

For Director General PA $^{1}$

${ }^{1}$ GHQ/6167/PSI. General Headquarters of the Ghana Armed Forces, Burma Camp, Accra, Ghana, letter dated 25th August, 1992 and mailed on 26th August, 1992. 
APPENDIX D

CHAPLAIN BRANCH OF THE ARMY 
The Chaplain Branch is a special branch of the Army whose officers are clergymen from recognized denominational groups who have volunteered to perform their ministry in the army. . . The private function of Army Chaplains to provide spiritual, religious, and moral leadership to the education, training and experience for the following duties.

a) Advise commanders at unit and higher levels concerning the spiritual, religious, and moral needs of their personnel.

b) Provide religious services, pastoral care, and counseling for:

i. Military personnel and their dependents at military installations.

ii. Military personnel and their dependents in hospitals and medical centers.

iii. Military personnel in confinement and rehabilitation centers.

iv. Military personnel in the combat zone on the battlefield.

v. Plan and direct religious education at military installations for military personnel and dependents.

vi. Participate in planning and initiating character guidance programs at every echelon of command.

vii. Plan and present character guidance briefing and instructions to members of the command.

viii. Manage the administrative programs which support chaplain activities at all echelons of the command.

ix. Manage chaplain personnel development, training and assignment at all echelons of command.

$\mathrm{x}$. Prepare and supervise religious programs for reserve activities at major commands and high levels.

xi. Formulate professional plans, policies, and programs, and their method of execution, up to DA level.

xii. Design visual training aids to include participation in the preparation of training films for religious education programs. 
xiii. Write professional and military material for texts, news media, and staff.

${ }^{1}$ Army Regulation 10-6: Branches of the Army by Department of the Army Office of the Chaplains, Washington, DC, 17th June 1970, 2-18. 
APPENDIX E

E. G. WHITE AND SEVENTH-DAY ADVENTIST TEACHING ON MILITARY SERVICE 
Ellen G. White's Views

Ellen Gould Harmon was born in Gorham, Maine, November 26, 1827. At the age of nine, while returning from school one afternoon, she was injured by a stone thrown by a classmate. This accident nearly cost her life. For three weeks she was unconscious, and in the years that followed she suffered greatly as a result of the serious injury to her nose. Ellen was unable to continue her schoolwork. In December, 1844, when Ellen was 17, she experienced the first of an estimated 2,000 visions she received during her lifetime. In August 1846, she married James White, a 25 year-old Adventist minister who shared her conviction that God had called her to do the work of a prophet.

Ellen white was a prolific writer. Beginning in 1851, when she published her first book, she sent forth a steady stream of articles, books, and pamphlets. Seventh-day Adventists believe that Mrs. Ellen G. White had the prophetic gift. They believe that God revealed Himself to her in visions and dreams, and that through her, He sent divinely-inspired messages to His church. Four of the numerous biblical reasons for this belief are as follows:

1. God's Word declares that spiritual gifts, including prophecy, will be present in the church throughout 
the New Testament period. 1 Cor. 12:1-11, 27-31; Eph. $4: 7,8,11-15$.

2. The Holy Scriptures state specifically that God's last-day, remnant, commandment-keeping church will possess the gift of the spirit of prophecy. Rev. $12: 17 ; 19: 10$.

3. Mrs. White's life and work provide overwhelming evidence of her divine calling.

4. Her life bore the fruit of a prophet (Matt. 7:15-20). Constantly, she labored to relieve suffering, to inspire courage, and to save the lost.

While the debate about Ellen White's view on war continues in the minds of many Seventh-day Adventists, her position with regards to bringing the gospel to military personnel is very clear. She wrote:

Christ commissioned His disciples to proclaim a faith and worship that would have in it nothing of caste or country, a faith that would be adapted to all peoples, all nations, all classes of man. ${ }^{1}$

To Ellen white, the gospel knows no caste, no class, nor profession. All men must be given the opportunity to accept or reject the gospel. She wrote:

But the command, "Go ye into all the world, is not to be lost sight of. We are called upon to lift our eyes to the "regions beyond." Christ tears away the wall of partition, the dividing prejudice of nationality and teaches a love for all the human 
family. He lifts men from the narrow circle which their selfishness prescribes; he abolishes all territorial lines and artificial distinctions of society. He makes no difference between neighbors and strangers, friends and enemies. He teaches us to look upon every needy soul as our brother, and the world as our field. . . The hardest and most unpromising field was not to be passed by. ${ }^{1}$

While God's prophecy through White makes it clear that all men must be reached with the gospel and that this includes military men and women and their families, her views on war and Adventist participation in war have sometimes resulted in debate among some Adventists. It seems that this paper should examine these issues as consideration of this issue will be needed by some Adventists planning to join the armed forces. One must distinguish, though, between Adventists who joined the armed forces because of economical necessity (in a time when joining the army was on a voluntary basis), and those who are already in the armed forces or became Adventists after entering the armed forces. For Adventists to extend the gospel to individuals in the armed forces (one of the world's largest professions with about a million in the USA, 2 million in China, a million in Iraq, and thousands in every country of the world), we need to extend military chaplaincy to all the ranks in the armed forces.

Concerning war in biblical times, E. G. White wrote:

${ }^{1}$ White, The Desire of Ages, 823,824 . 


\begin{abstract}
Seeking first of all divine counsel, Abraham prepared for war. From his own encampment, he summoned three and eighty trained servants, men trained in the fear of God, in the service of their master, and in the practice of arms. . . His attack, so vigorous and unexpected, resulted in the speedy victory. The king of Elam was slain, and his panic-stricken forces were utterly routed. . . To Abraham, under God, the triumph was due. The worshiper of Jehovah had not only rendered a great service to the country, but proved himself a man of valor. It was shown that righteousness was not cowardice, and that Abraham's religion made him courageous in maintaining the right and defending the oppressed. . . Abraham regarded the claims of justice and humanity. His conduct illustrates the inspired maxim: "Thou shalt love thy neighbor as thyself."1
\end{abstract}

To Ellen White, a Christian is bound to obey the laws of the land until and unless it is in conflict with God's higher law. She wrote:

I saw that it is our duty in every case to obey the laws of our land, unless they conflict with the higher Law which God spoke with audible voice from Sinai, and afterward engraved on stone with His own finger. "I will put my laws into the mind and write them in their hearts; and I will be to them a God, and they will be to me a people." He who has God's law written in their heart will obey God rather than man and will sooner disobey all men than deviate in the least from the commandment of God. God's people, taught by the inspiration of truth, will take His law, written in their hearts, as the only authority which they can acknowledge or consent to obey. The wisdom and authority of the divine law are supreme. ${ }^{2}$

Ellen G. White wrote concerning the civil War, which she called a "perplexing war," that God was using it to

${ }^{1}$ Ellen G. White, Patriarchs and Prophets, 135-136; idem, The Great controversy 56, 244, 271. White, by inspiration, wrote about how God preserved His message through wars that were fought.

$$
{ }^{2} \text { E. G. White, Testimonies to the Church, 1983, 1, }
$$


punish both the North and the South, a war in which God was rather on the side of the North. ${ }^{1}$

I was shown that God's people, who are His peculiar treasure, cannot engage in this perplexing war, for it is opposed to every principle of their faith. In the army they cannot obey the truth and at the same time obey the requirements of their officers. There would be a continual violation of conscience. Worldly men are governed by worldly principles. They can appreciate no other. Worldly policy and public opinion compromise the principle of action that governs them and leads them to practice the form of rightdoing. But God's people cannot be governed by these motives. Those who love God's commandments will conform to every good law of the land. But if the requirements of the rulers are such as conflict with the laws of God, the only question to be settled is shall we obey God or man.2

One must note that Ellen White wrote this when no

provision was made for sabbath observance or non-combatancy.

Even though she gave a strong admonition to Adventists

against participation in the civil War, she cautioned the

Sabbath-keepers to use heavenly wisdom to turn away

suspicion as to the opposition to this war. She wrote:

There was need in moving with wisdom to turn away the suspicions excited against Sabbath-keepers. We should act with great caution. "If it be possible, as much as lieth in you, live peaceable with all men." We can obey this admonition and not sacrifice one principle of our faith. Satan and his host are at war with commandment-keepers, and will work to bring them into trying positions. They should not, by lack of discretion, bring themselves there. ${ }^{3}$

She cautions those who openly were opposing the draft,

${ }^{1}$ E. G. White, Testimonies, 1:359, 365, 368 .

${ }^{2}$ Ibid. , 361, 362 .

${ }^{3}$ Ibid. , 365 . 
those who boldly asserted that they would die rather than submit to the draft. She said the Lord may not be on their side. She declared:

I saw that those who have been forward to talk so decidedly about refusing to obey a draft, do not understand what they are talking about. Should they really be drafted and refusing to obey, be threatened with imprisonment, torture, or death, they would shrink, and then find that they had not prepared themselves for such an emergency. They would not endure the trial of their faith. What they thought to be faith was only fanatical presumption. Those who would be best prepared to sacrifice even life if required, rather than place themselves in a position where they could not obey God, would have the least to say. They would make no boast. They would feel deeply and meditate much, and their earnest prayers would go up to Heaven for wisdom to act and grace to endure. Those who feel that in the fear of God they cannot conscientiously engage in this war will be very quiet, and when interrogated will simply state what they are obliged to say in order to answer the inquirer, and then let it be understood that they have no sympathy with the Rebellion.

It is essential that White's comments about the perplexing civil war not be taken out of context. They must be understood as the period when military service was on an enlistment basis only and no provisions whatsoever were made for the conviction of individual conscience. After March 1863, the "Enrollment Law" was passed by the Congress of the United states. This law made provision for those who conscientiously opposed the bearing of arms, and those who

${ }^{1}$ White, Testimonies, $1: 357$. 
were drafted could ask to be classified noncombatants. ${ }^{1}$ The Seventh-day Adventist Church sought and was granted recognition as noncombatants.

It is fair to say that Ellen white did not oppose military service, but she seemed to admonish Seventh-day Adventists who are called to duty to excel in christian character and to serve as Christ's ambassadors. When White was in Europe, she wrote three Swiss men who were called to service.

We have just said farewell to three of our responsible men in the office which were summoned by the government to serve for three weeks of drill. It was a very important stage of our work in the publishing house, but the government calls do not accommodate themselves to our convenience. They demand that young men whom they have accepted as soldiers shall not neglect the exercise and drill essential for service. We were glad to see that these men with their regimentals had tokens of honor for faithfulness in their work. They were trustworthy young men. These did not go from choice, but because the laws of their nation required this. We gave them a word of encouragement to be found true soldiers of the cross of Christ. Our prayers will follow these young men, that the angels of God may go with them and guard them from every temptation. ${ }^{2}$

When the purpose of Seventh-day Adventist men or women who enter the armed forces as chaplains is to present the

\footnotetext{
${ }^{1}$ Noncombatants refers to men and women who are conscientiously opposed to the bearing of arms; when such people are being drafted, they are assigned to work in hospitals or army non-arms-bearing duties.

${ }^{2}$ Ellen G. White Publication "Recognition of European Military Service Laws" Washington 12, DC June $15^{\text {th }}$ 1956(Written from Basel, Switzerland september 2, 1886) Ellen G. White Uncopied Letter 23, 1886 .
} 
gospel as Adventists see it, to the thousands of men and women in uniform, they will be blessed. They also must defend the religious rights of many who become seventh-day Adventists while in the armed forces. White's counsel to chaplains is that they pray that the angels of God will go with them in order for them to be found as a "true soldier of the cross of christ."

In summarizing Ellen White's position on Adventists in military chaplaincy, one may conclude that God wants all men, without respect to profession, cast, or nationality, to be given a chance to accept or reject the three angels message. Adventist military chaplains stand in a better position to fulfill this mission in the armed forces. Adventist military chaplains defend the rights of all Adventists in the armed forces, while at the same time they bring military men and women to the knowledge of Christ and His true remnant.

\section{Seventh-day Adventist View on Military Chaplaincy}

From total opposition to an Adventist military ministry in the armed forces to the total acceptance and recommendation for Adventist ministers to join the armed forces as chaplains, took the Adventist Church almost eighty years $(1865-1944)$.

The reluctance of the Seventh-day Adventist Church to allow pastors to become military chaplains is explained 
by one Adventist Navy chaplain.

The Seventh-day Adventist denomination with its great emphasis on the separation of church and state was reluctant to send pastors into a situation which appears to compromise this principle. ${ }^{1}$

After the Civil War in 1865, the Seventh-day Adventist Church did not give much attention to military service. It became an almost forgotten issue. But at the end of World War I, many Adventist men and women were in jail because of their refusal to bear arms. The church seriously began to consider the issue of Adventists and war and Adventists and the armed forces.

Late in the 1920s and early 1930 s the seventh-day Adventist Church came to the realization that the two greatest problems of Adventists in military service was the nonbearing of arms (non-combatancy) and sabbath observance. Church leaders believed this could be solved by Adventists joining the military medical service. ${ }^{2}$ This led to the

${ }^{1}$ Barry Black, "Seventh Day Adventist Military Chaplain: A Study of Belief and Functions in Tension with Military Life," 8, 9.

${ }^{2}$ Barry Black "Seventh Day Adventist Military Chaplains," 17. Dr. Black also in pages 17-18 wrote that the church leaders decided that if all Adventist military people get into the medical branch, the greatest problems of 191718 would be eliminated. Hence the faculty at Union College took action on this idea and sought help from the Army Medical Department to train the young people in skills that would secure their medical assignments if drafted.

The basic well developed training program was designed by White Memorial Hospital in Los Angeles, which taught Adventists how to be medical soldiers. These two programs were considered and in 1940 it became the SDA Medical cadet Corps. 
birth of the Medical Cadet training program for Adventist men. Young people in the church joined the Medical cadet Corp, in an effort to obey the counsel of God through Ellen White. They also believed that Adventists in medical missionary work could be an entering wedge.

Nothing will open doors for the truth like evangelistic medical missionary work. This will find access to the heart and minds. . . The medical missionary work is the right, helping hand of the Gospel, to open doors for the proclamation of the message. Doors that have been closed to him who merely preaches the Gospel will be opened to the intelligent medical missionary. God reaches hearts through the relief of physical suffering. It is the pioneer work of the Gospel, the door through which the truth for this time is to find entrance to many homes. It is to be a great entering wedge, whereby the diseased soul may be reached. ${ }^{1}$

In 1971, the Seventh-day Adventist Church discontinued the SDA Medical Cadet Corps training program they started in the late 1930s. The basis for its cessation was that its functions are accomplished by the National Service Organization of Seventh-day Adventists. ${ }^{2}$

The Seventh-day Adventist War Commission formed in 1918 deactivated not long after it was formed. It was reactivated in 1940 under the National Service Commission. In 1954, the National Service organization replaced the National Service Commission. This organization was assigned the responsibility of supervising all military-related

${ }^{1}$ Ellen G. White, Evangelism, 513-514.

${ }^{2}$ Barry Black, "Seventh day Adventist Military Chaplaincy," 20. 
aspects of the church and also functioned as selector and endorser of military chaplains. ${ }^{1}$

With many Seventh-day Adventists serving in the military, the United State Army requested Adventist chaplains in 1941. The church accepted the invitation, based on various reasons but without any commitment or approval. ${ }^{2}$

Probably the most outstanding decisions made by the Seventh-day Adventist Church against military chaplaincy occurred in 1943 when the church voted down the request of the U.S. Navy for Adventist chaplains. At the same time, the church warned Seventh-day Adventist ministers from accepting ministerial positions in the armed forces. What made this vote so outstanding was not the voting down of the request, since in both 1942 and 1943 and other occasions the church voted down such proposals. The warning was:

Military Chaplains are Ministers of religion to the armed forces. They are employed by the government and are remunerated from public funds for the teaching of

${ }^{1}$ Philip G. Benson, "The Rise of Organization within the Missionary Volunteer Department as Related to the Military," unpublished paper, Andrews University, July 13, $1973,14,15$.

${ }^{2}$ Barry Black, "The Seventh Day Adventist Military Chaplaincy," 23. Dr. Black, s reasons for acceptance of this invitation from the army, were based on the following: 1. In religious matters affecting people in the service the government dealt only with organizations which have received official recognition for this purpose. 2. By accepting, there were advantages to be gained not otherwise possible in ministering to the spiritual needs of SDA members in the armed forces. 
religion. This is a practice which is in clear violation of biblical principles concerning the separation of church and state. The teaching of religion is the duty and responsibility of the church and it is wholly improper for the state to employ individuals for this specific purpose. . . . 1

The church did not take any action on the chaplaincy issue until the 1950 General Conference Autumn Council Meeting. The resolution voted and adopted by this council reads :

Whereas, there seems to be a field of opportunity for successful spiritual work by men acting as chaplains. - Resolved: That we place no barrier in the way of Seventh-day Adventist ministers of maturity and high spiritual experience undertaking this line of work should they feel personally called to do so; and further, that any who are in good and regular standing, will continue to receive credentials from the seventhday Adventist denomination, and while the time spent in the service of the armed forces will not add to their church record, it will not be considered a break in such record. 2

Floyd Bresee was the first Seventh-day Adventist to accept a commission as an Army chaplain in 1943. By July 1976, Adventists had 36 chaplains in the Army, Navy, and Air Force. By 1998 many more Seventh-day Adventists have become chaplains a result of the fact that the church (Seventh-day Adventist) has endorsed military chaplaincy.

The church now has a well-established means by which one can become a chaplain in the military without much

${ }^{1}$ General Conference Committee Minutes, May 20, 1943.

21950, Autumn Council General Conference Minutes, Unpublished Documents, Ellen White Estate, Berrien Springs, Andrews University. 
resistance. Many have written about Seventh-day Adventist military chaplaincy, but the person who has gone a step further than anyone is Robert $\mathrm{L}$. Mole. His work on military chaplaincy deserves our appreciation. ${ }^{1}$

The noncombatant position has been steadfastly maintained by Seventh-day Adventists throughout history. This does not mean Adventists have stood apart from war. They consistently have endeavored to cooperate in every possible line of non-combatant service. The Seventh-day Adventist Church sees in war situations an opportunity to render valuable Christian service by relieving suffering and saving life. Seventh-day Adventists are willing to serve wherever they can best be used, in the military forces in civil defense or in humanitarian service. ${ }^{2}$ Seventh-day Adventist men and women have served compassionately wherever people are in need. They believe they live in a time when wars and evil are worse; hence, every opportunity of service must be approached seriously.

${ }^{1}$ Robert L. Mole, He Called Some To Be Chaplains: $\underline{A}$ Brief overview of Seventh-day Adventist Church and Its Chaplaincies in the Military Veteran $s$ Administration, Correctional Facilities and in Non-Adventist Operated Institutions Washington DC: General Conference of Seventhday Adventist, 1982

${ }^{2}$ William H. Branson, "Medical Training provided by the Seventh-day Adventist Church," introductory page. 
APPENDIX F

BRIEF EXPLANATION OF THE SEVENTH-DAY ADVENTIST CHURCH POSITION ON BEARING OF ARMS 
Brief Explanation of the Seventh-day Adventist Church Position on Bearing of Arms

There are three valid conscientious positions usually taken by Seventh-day Adventist church members on military service.

1. Total conscientious objectors.

2. Non-combatancy.

3. Full military participation (Combatancy).

The church recommends non-combatancy as preferred because it is both consistent with the Christian mission of saving life but not taking life and with Christian's loyalty to the government. 
BIBLIOGRAPHY 


\section{BIBLIOGRAPHY}

Abercrombie, Lawrence L. The Military Chaplain. London:

Sage Publications, 1977.

"Acts and Romans." The Pulpit Commentary. Edited by H. M. D. Spencer. Grand Rapids: WM. B. Eerdmans, 1997. $18: 346$.

Adinkrah, Mensah. "Political Coercion in Military-Dominated Regimes." Thesis, Washington University, 1988.

Addo, Ebenezer Obiri. "Kwame Nkrumah: A Case Study of Religion and Politics in Ghana." Thesis, Drew University, 1994 .

Andersen-Mensah, Robert Anaasse. "Towards the Contextualization of Religious Education Rites of Passage as Processes of Socialization in Contextual Religious Education." Thesis, Presbyterian School of Christian Education, 1993.

Appelquist, A. Ray. Church, State, and Chaplaincy: Essays and Statements on the American Chaplaincy system. Washington, DC: General Commission on Chaplains and Armed Forces Personnel, 1969.

Anderson, Stanley E. Shepherds to 24,000,000 service Men. Butler, IN: Higley Press, 1954 .

Baynham, Simon. The Gold Coast Military Forces: origins, Composition and Structure. Pretoria: African Institute of South Africa, 1994.

Bebler, Anton. Military Rule in Africa: Dahomey, Ghana, Sierra Leone and Mali. New York: Praeger Pub., 1973.

Black, Barry C. The Seventh-day Adventist Military Chaplain: A Study of Beliefs and Functions in Tension With Military Life. Ann Arbor, MI: University Microfilms, 1982 .

Boesak, Allan A., ed. Churches and Apartheid--A Call to Prayer: When Prayer Makes News. Philadelphia: Westminster Press, 1984. 
Boyle, Beth Ellen. Words of Conscience. $10^{\text {th }}$ ed. Washington, DC: National Inter-Religions Service Board for Conscientious objectors, 1983.

Brown, Paul. Insignia of the Services. New York: Charles Scribner's Sons, 1941 .

Buabeng, Isaac. Short History of Burma Camp Seventh-day Adventist church. Accra: Barracks Press, 1993.

Caskie, Donald c. The Tartan Pimpernel. London: oldbourne, 1959 .

Chaplain General's Department. "Recognition of Religious Bodies in the Armed Forces," Accra: General

Headquarters, Ghana Armed Forces, 1970.

Collins, Gary R. Christian Counseling. Dallas: Word Publishing, n.d.

Collins, Julian Edward. "Military Intervention in African Politics: Ghana and Nigeria." Thesis, University of Minnesota, 1969.

Cox, Harvey Gallagher. Military Chaplains: From Religious Military to a Military Religion. New York: American Report Press, 1973.

Crocker, Lawrence P. The Army Officer's Guide. Harrisburg: Stackpole Books, 1988 .

"Daniel." Seventh-day Adventist Bible commentary. Edited by F.D. Nichol. Washington, DC: Review and Herald Pub. Assn; 1953-57. 4:859-861.

"Defense--Ghana, Introductory Survey." The Europe World Yearbook. London: Europa Publication, 1995.

Dehoney, Wayne. Disciples in Uniform. Nashville: Broadman Press, 1967 .

Demobilization and Resettlement of Gold Coast Africans in the Armed Forces. Accra: Government Printing Department, 1945 .

Drury, clifford Merrill. The History of the Chaplain Corps, United States Navy. Washington, DC: U.S. Government Printing office, 1948-85.

Embry, Margaret. Everyday Life in Biblical Time: Work, Worship and war. Nashville: T. Nelson, 1994. 
"Exodus." Seventh-day Adventist Bible Commentary. Edited by F.D. Nichol. Washington, DC: Review \& Herald Pub. Assn., 1953-57. 1:606.

Forson, Mathias K. Split-level Christianity in Africa: A study of the Persistence of Traditional Religious Beliefs and a Practice Among the Akan Methodists of Ghana. Accra: Asbury Theological Seminary Research, 1993.

"Genesis." Seventh-day Adventits Bible Commentary. Edited by F. D. Nichol. Washington, DC: Review and Herald, 1953-57.

Ghana Armed Forces Communication (GHQ/14022/RA). "Recognition of Religious Bodies in the Armed Forces." Chaplain General's Department, General Headquarters, Ghana Armed Forces, Burma Camp, Accra, December 1970.

Ghana, 1981-1991: A Decade of Unity, Stability and Development. Accra: Information Service Dept., 1992.

Ghana Demographic and Health Survey. Accra: Ghana Statistical Service, 1994 .

Granfield, Charles. Romans: A Shorter Commentary. Grand Rapids: Eerdmans Publishing Co., 1985.

Gutteridge, William Frank. Africa's Military Rulers. London: Institute for the study of Conflict, 1975.

Haney, James Ray. "Toward an Ethnic Theology." Thesis, Midwestern Baptist Theological Seminary, 1993.

Harris, David. "Tame." Theological Wordbook of old Testament. Edited by Laird Harris. Chicago: Moody Press, 1980.

Haywood, A., and F. A. S. Clarke. The History of Royal West African Frontier Force. Aldershot: Gale and Palden, 1964 .

Helgeland, J. John. Christians and the Military: The Early Experience. Philadelphia: Fortress Press, 1985.

Headley, Joel Tyler. The Chaplains and Clergy of the Revolution. New York: C. Scribner, 1864 .

Hodge, Charles. Commentary on the Epistle to the Romans. New York: Williams S. Martien, 1846. 
Howel, Edgar M. United States Army Headgear, 1855-1902. Washington, DC: U.S. Government Printing Office, 1975.

Insignia and Decorations of the United States Armed Forces. Washington, DC: National Geographic Society, 1944.

"John." Seventh-day Adventist Bible Commentary. Edited by F. D. Nichol. Washington, DC: Review and Herald, 1953-57.

Junes, Joseph B. The Ratification of the Fourteenth Amendment. N.p: Mercer University Press, 1984.

Kasemann, E. "New Testament Questions of Today." The Expositor's Bible Commentary. Edited by Frank E. Gaebelein. Grand Rapids: Zondervan Pub. House, 1976.

Kinchy, John. Those who Say No: A Chaplain's Guide tocounseling Conscientious objectors. Philadelphia: Central Committee for Conscientious objectors, 1976.

Korma, Kenneth. "The Military in Political Leadership in Ghana." Thesis, Eastern Illinois University, 1973.

Leader, Shelah Gilbert. "Military Professionalism, Intervention and the Disposition to Intervene in Ghana and Mali." Thesis, Ghana State University, 1971.

Lefever, Ernest W. Spear and Scepter: Army, Police, and Politics in Tropical Africa. Washington, DC: Brookings Institute, 1970 .

Lehman, Paul. Transfiguration of Politics. New York: Harper and Row, 1975; London: H. Greenwood and Co., 1979 .

Lindars, Barnabas. New Century Bible: The Gospel of John. London: Butler and Tanner, 1972.

Lord, Francis A. Uniforms of the Civil War. New York: Thomas Yoseloff, 1970.

"Luke." Seventh-day Adventist Bible Commentary. Edited by F. D. Nichol. Washington, DC: Review and Herald, 1953-57.

"Luke." The Pulpit Commentary. Edited by H.D.M. Spencer. Grand Rapids: WM. B. Eerdmans Company 1977. 17:394.

Lyth, J. "Christian Subjection (Roman 13)." In Biblical Illustrator, ed. Joseph S. Exell. Grand Rapids: Baker Book House, 1957. 4:562. 
Maguire, William A. Rig for Church. New York: Macmillan, 1942 .

Maxwell, C. Mervyn. "Non-Combatency or Pacifism." TMs. E.G. White Research Center, Andrews University, Berrien Springs, MI.

Ministerial Association of Seventh-day Adventists. Manual for Ministers. Washington, DC: General Conference of Seventh-day Adventists, 1977.

Mole, Robert L. He Called Some To Be Chaplains: A Brief overview of the Seventh-day Adventist Church and Its Chaplaincies in the Military Veterans Administration, Correctional Facilities and in Non-Adventist operated Institutions. Washington, DC: General Conference of Seventh-day Adventists, 1982.

National Service Organization of the General Conference of Seventh-day Adventists. "Seventh-day Adventist Teachings on Governmental Relations and NonCombatancy." Washington, DC: General Conference of Seventh-day Adventists, 1982.

"What an Adventist Should know About the Military." Washington, DC: General Conference of Seventh-day Adventists, n.d.

"Why Seventh-day Adventists Are Non-Combatants." Washington, DC: General Conference of Seventh-day Adventists, 1917.

"Nero." Encyclopedia Britannia. 1953 ed. Quoted in Frank Leo Finkbiner. Church and State from Paul-1 Peter. Ann Arbor: University of Michigan, 1960.

North, James J., Jr. Chaplaincy Ministries: The Development and Implementation of a course in specialized Ministries as Vehicles for Seventh-day Adventist SelfUnderstanding and Expression of Mission. Berrien Springs, MI: Andrews University Press, 1988.

Nugent, Paul. Biq Men and Small Boys: Power, Ideology and the Burden of History in Rawlings' Ghana, 1982-1994. London: Mansell, 1995.

Ocran, A. K. Politics of the Sword: A Personal Memoir on Military Involvement in Ghana and of Problems. London: R. Collings, 1977 . 
olorunsola, Victor A. Societal Reconstruction in Two African States. Washington, DC: University Press of America, 1977.

Owusu, Emmanual K. "Ghana Armed Forces Secondary School." Thesis, University of Washington, 1980.

Pfeffers, Leo. Preface to Religious Freedom. Chicago: National Textbook Company, 1987.

"Romans." Seventh-day Adventist Bible Commentary. Edited by F.D. Nichol. Washington, DC: Review \& Herald Pub. Assn., 1953-57. 6:626.

Rawlings, Jerry J. The Way Ahead. Accra: Ghana Armed Forces Staff college, 1990.

Reuke, Ludger. Befreier und Erloser? Bonn-Bad Godesberg: Verlag Neue Gesellschaft, 1976.

"Sar-Shalom." Theological Wordbook of the old Testament. Edited by R. Laird Harris. Chicago: Moody Press, 1980. 884 .

Solt, Leo F. Saints in Arms: Puritanism and Democracy in Cromwell's Army. Stanford, CA: Stanford University Press, 1959 .

Spence, H.M.D. The Pulpit Commentary. Grands Rapids, MI: Wm. B. Eerdmans Pub., 1977.

Symposium on the Life and Work of Kwame Nkrumah. The Armed Forces Under Kwame Nkrumah. Legon, Ghana: Institute of African Studies, University of Ghana, 1985.

Thompson, Parker c. The Chaplaincy of the United States Army: A Manual for Assisting Clergy in Making a Meaningful Career Choice. Ann Arbor, MI: University of Michigan Press, 1990.

- From Its European Antecedents to 1791.

Washington, DC: Office of the Chief of Chaplains, Dept. of the Army, 1978.

Thomas, Marlin E. Yahweh War in Early Israel: An Inquiry into the Significance of God's Role in the Early Wars of Israel. Deerfield, IL: Mennonite Brethren Biblical Seminary, 1966.

Trustees of Ellen G. White Publications. Preface to Evangelism, by Ellen G. White. Washington, DC: Review \& Herald Pub. Assn., 1974. 
Uniform Regulations for the Army of United States. Washington, DC: Smithsonian Institution, 1961.

U.S. Department of the Army. Field Manual 16-5: The Chaplain. Washington, DC: U.S Department of the Army, 1977.

- FM 16-1 Religious Support and Doctrine: The Chaplain and Chaplain Assistant. Washington, DC: Department of the Army, 1989.

Army Requlation 165-1 Chaplain Activities in the United States Army. Washington, DC: Department of the Army, 1989 .

"The Supervisory Chaplain Brigade Level."

Training Circular No. 16-12. Washington, DC:

Department of the Army, 1979.

"The Chaplain as Pastoral Coordinator." Training Circular No. 16-11. Washington, DC: Department of the Army, 1979 .

The Visual Dictionary of Military Uniforms. New York: Dorling Kindersley, 1992 .

Webster's Third International Dictionary. Cambridge, MA: Merriam Webster, 1986. S.v. "Battery"; "Chaplain."

White, Ellen G. Acts of the Apostles. Washington, DC: Review and Herald Pub. Assn., 1974.

- The Adventist Home. Washington, DC: Review and Herald Pub. Assn., 1988.

- The Desire of Ages. Washington, DC: Review \& Herald Pub. Assn., 1974.

- Education. Mountain View, CA: Pacific Press Pub. Assn., 1952 .

Evangelism. Washington, DC: Review and Herald Pub. Assn., 1974 .

Gospel Workers. Washington, DC: Review \& Herald Pub. Assn., 1915.

- The Great Controversy. Mountain View, CA: Pacific Press Pub. Assn., 1950.

- Ministry of Healing. Boise, ID: Pacific Press

Pub. Assn., 1950. 
Patriarchs and Prophets. Mountain View, CA: Pacific Press Pub. Assn., 1958.

Testimonies to Ministers. Washington, DC: Review \& Herald Pub. Assn, 1974.

Testimonies for the Church. Vol. 9. Washington, DC: Review \& Herald Pub. Assn., 1974.

Welch, claude Emerson. Soldiers and State in Africa: A Comparative Analysis of Military Intervention and Political Change. Evanston, IL: Northwestern University Press, 1970.

Wilson, Michael. The Hospital--A Place of Truth: A Study of the Role of the Hospital Chaplain. Birmingham: University of Birmingham Institute for the Study of Worship and Religious Architecture, 1971.

Zahn, Gordon Charles. The Military Chaplaincy: A study of the Role of Tension in the Royal Air Force. Toronto: University of Toronto Press, 1969.

Zeff, Eleanor Elwell. "An Analysis of Difference and similarities Between Military and Civilian Regimes in Ghana." Thesis, University of Ghana, 1986. 
VITA

Personal and Family:

Name: Peter Kwasi Omane

Date and Place of Birth: September 3, 1961, Ejuso

Ashanti, Ghana

Wife's Name: Linda Ohenewaa Omane

Children's Name, Date and Place of Birth:

Jonathan Kofi Omane, November 10, 1989, Berrien

Springs, MI, USA

Kofi Danso Omane, October 9, 1992, Berrien Springs, MI, USA

Kofi Aboagye Omane, September 15, 1995, Berrien

Springs, MI, USA

Education, Diplomas, and Degrees/Certificates Awarded:

Bachelor of Arts in Religion and Biblical Languages,

West Indies College, Mandeville, Jamaica, 1989

Certified Nursing Assistant, 1991

Master of Divinity, Andrews University, Berrien Springs, MI, 1992

Doctor of Ministry, Andrews University, Berrien Springs, MI, 1998

Work Experience:

1981-1983

$1984-1985$

$1985-1986$

1987-1989

1989-1991
Lay Evangelist, Central Ghana Conference of SDA Church, Kumasi, Ghana

Acting Lay Pastor and Evangelist, Burma Camp SDA Church, Accra, Ghana

Literature Evangelist, North India Union, New Delhi, India

Literature Evangelist, Skandinaviska Bokfolaget, Sweden, Europe

Ministry to the Developmentally

Disabled, Residential Services of Southwestern Michigan, USA 
1989-Present Pastoral Assistant, Chicago Ghanaian SDA Church, Illinois, USA

1991-Present Ministry to the Elderly as Certified Nursing Assistant, Lakeland Continued Care Center, St. Joseph, Michigan, USA

1995-Present Ministry to the Developmentally Disabled, Residential Services of Southwestern Michigan, USA

1996-Present Secretary, Andrews University Ghanaian Fellowship, Michigan, USA 